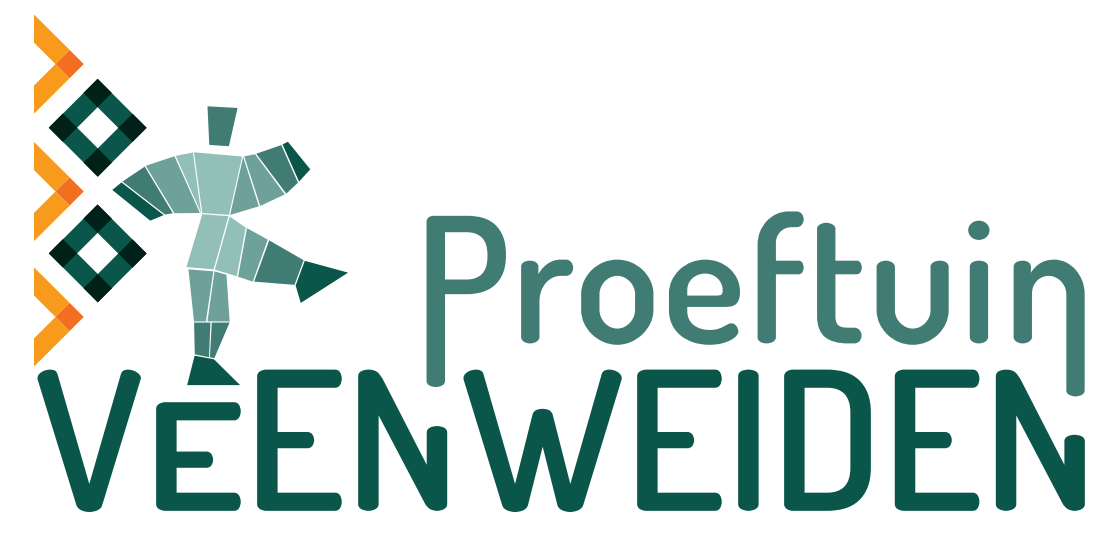

Analyse van gedragsverandering bij het verminderen van de ammoniakemissie in de Proeftuin Veenweiden

Paul Galama, Maikel Timmerman

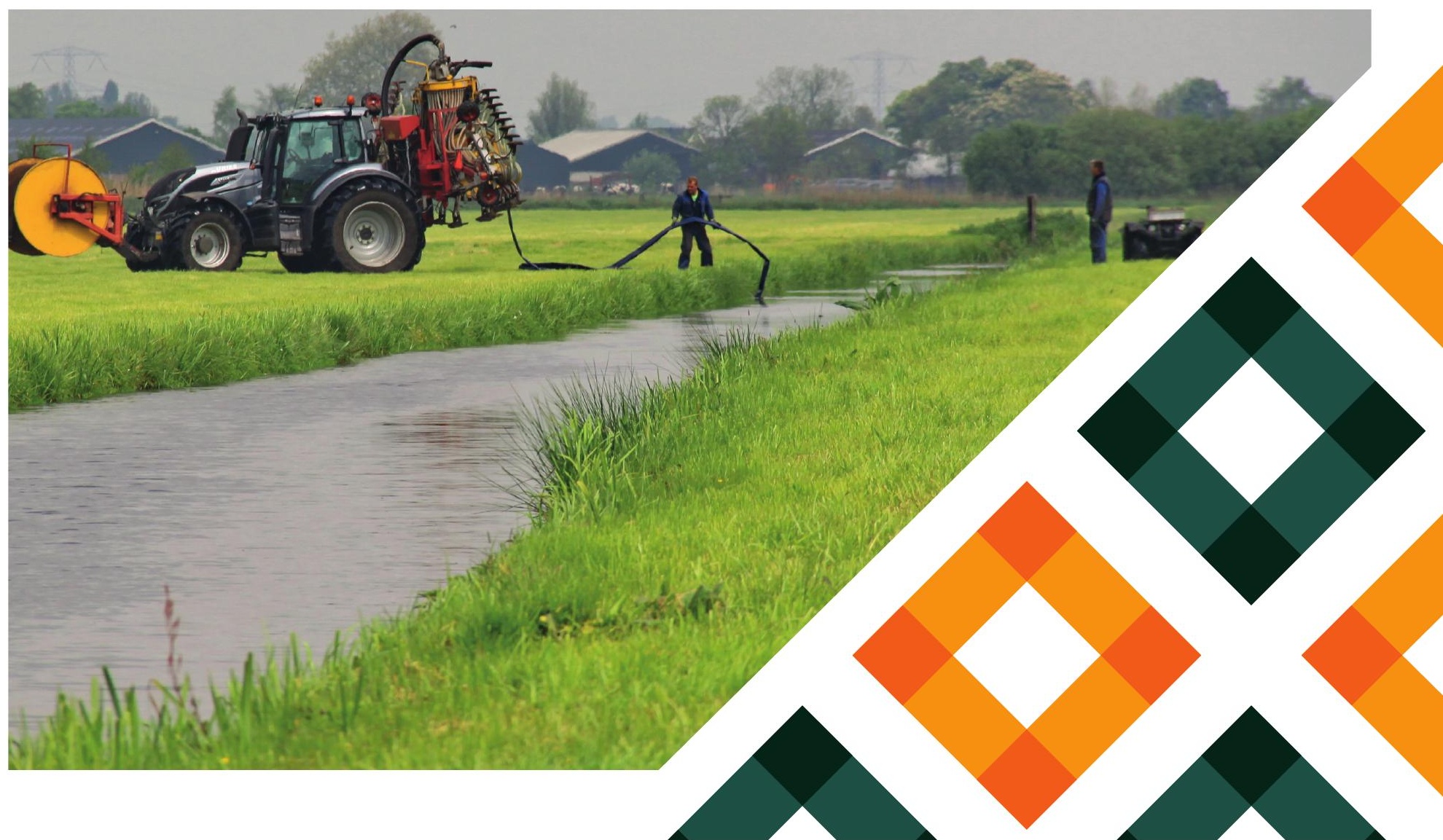





\section{Analyse van gedragsverandering bij het verminderen van de ammoniakemissie in de Proeftuin Veenweiden}

P. Galama, M. Timmerman

Wageningen Livestock Research

LTO Noord startte begin 2016 met het innovatieprogramma Proeftuin Veenweiden en wordt daarbij financieel ondersteund door provincie Zuid-Holland, het Ministerie van Landbouw, Natuur en Voedselveiligheid, het Melkveefonds en het LTO Noord Fonds. De Proeftuin is een initiatief van LTO Noord en VIC Zegveld. De uitvoering van het programma is in handen van LTO Noord, Wageningen University \& Research, VIC Zegveld, PPP-Agro Advies en het Louis Bolk Instituut. 
Galama, P., M. Timmerman, 2019. Analyse van gedragsverandering bij het verminderen van de ammoniakemissie in de Proeftuin Veenweiden. Wageningen Livestock Research, Rapport 1180.

\section{Samenvatting}

Dit rapport is een verslag van gedragsonderzoek bij pilot- en volgerboeren in Proeftuin Veenweiden. Het geeft inzicht in de belangrijkste maatregelen die genomen zijn om de ammoniakemissie te reduceren en wat daarbij motiveert en belemmert of demotiveert. Ook zijn aanbevelingen gedaan om de kennisinfrastructuur in het algemeen te versterken.

\section{Summary}

This is a report about behavioral research among pilot and follower farmers in 'Proeftuin Veenweiden'. It provides insight into the most important measures that have been taken to reduce ammonia emissions and what motivates and hinders or demotivates them. Recommendations have also been made to strengthen the knowledge infrastructure in general.

Dit rapport is gratis te downloaden op https://doi.org/10.18174/495796 of op www.wur.nl/livestock-research (onder Wageningen Livestock Research publicaties).

\section{(C) 2019 Wageningen Livestock Research}

Postbus 338, 6700 AH Wageningen, T 03174839 53, E info.livestockresearch@wur.nl, www.wur.nl/livestock-research. Wageningen Livestock Research is onderdeel van Wageningen University \& Research.

Wageningen Livestock Research aanvaardt geen aansprakelijkheid voor eventuele schade voortvloeiend uit het gebruik van de resultaten van dit onderzoek of de toepassing van de adviezen.

Alle rechten voorbehouden. Niets uit deze uitgave mag worden vermenigvuldigd en/of openbaar gemaakt worden door middel van druk, fotokopie, microfilm of op welke wijze dan ook zonder voorafgaande toestemming van de uitgever of auteur.

Wageningen Livestock Research is NEN-EN-ISO 9001:2015 gecertificeerd. Op al onze onderzoeksopdrachten zijn de Algemene Voorwaarden van de Animal Sciences Group van toepassing. Deze zijn gedeponeerd bij de Arrondissementsrechtbank Zwolle. 


\section{Inhoud}

$\begin{array}{ll}\text { Samenvatting } & \mathbf{5}\end{array}$

$\begin{array}{ll}\text { Synthese en reflectie } & 7\end{array}$

$\begin{array}{ll}1 & \text { Inleiding }\end{array}$

$\begin{array}{lll}1.1 & \text { Achtergrond } & 21\end{array}$

1.2 Doel 21

$2 \quad$ Materiaal en Methode $\quad 22$

$2.1 \quad$ Interviews bij melkveehouders $\quad 22$

2.2 Enquête onder deelnemende melkveehouders $\quad 22$

$\begin{array}{lll}2.3 & \text { Interviews bij begeleiders, adviseurs en loonwerker } & 23\end{array}$

$\begin{array}{lll}2.4 & \text { Methode } & 23\end{array}$

$\begin{array}{llr}3 & \text { Resultaten } & 25\end{array}$

$\begin{array}{lll}3.1 & \text { Algemeen } & 25\end{array}$

3.2 Typering van de melkveehouders $\quad 25$

$\begin{array}{lll}3.3 & \text { Maatregelen } & 28\end{array}$

$\begin{array}{lll}3.4 & \text { Motieven voor gedragsverandering } & 33\end{array}$

$\begin{array}{lll}3.5 & \text { Belemmeringen } & 37\end{array}$

3.6 Communicatie-activiteiten van de proeftuin 38

$\begin{array}{lll}3.7 & \text { Projectevaluatie } & 39\end{array}$

$4 \quad$ Discussie $r 4$

$5 \quad$ Conclusies en aanbevelingen $\quad 42$

$\begin{array}{lll}5.1 & \text { Conclusies } & 42\end{array}$

5.2 Aanbevelingen $\quad 43$

$\begin{array}{ll}\text { Literatuur } & 44\end{array}$

Bijlage $1 \quad$ Vragenlijst interviews melkveehouders $\quad 45$

Bijlage $2 \quad$ Vragen internet enquête $\quad 46$

Bijlage 3 Vragenlijst interviews begeleiders, adviseurs en loonwerker 54

Bijlage 4 Toepassing van ammoniak reducerende maatregelen 56

$\begin{array}{lll}\text { Bijlage } 5 & \text { Invloedsfactoren } & 61\end{array}$

$\begin{array}{lll}\text { Bijlage } 6 & \text { Kennisvergaring } & 64\end{array}$

$\begin{array}{lll}\text { Bijlage } 7 & \text { Belemmeringen } & 65\end{array}$

Bijlage 8 Doelen Duurzame Zuivelketen $\quad 66$

$\begin{array}{lll}\text { Bijlage } 9 & \text { Mindset ondernemer } & 67\end{array}$

$\begin{array}{lll}\text { Bijlage } 10 & \text { Kennisvergaring proeftuin } & 68\end{array}$

$\begin{array}{lll}\text { Bijlage } 11 & \text { Verloop van Proeftuin Veenweiden } & \mathbf{7 0}\end{array}$ 


\section{Samenvatting}

\section{Doel}

Het doel van het gedragsonderzoek is te ontdekken waarom melkveehouders in samenwerking met adviseurs en loonwerkers in de Proeftuin Veenweiden bepaalde maatregelen wel of niet nemen om de ammoniakemissie te beperken. Aan de hand van factoren die het gedrag beïnvloeden zijn aanbevelingen gedaan hoe je impact kunt creëren bij een grote groep melkveehouders.

\section{Methode}

Er zijn vijf pilotboeren, vijf boeren uit de ontwikkelteams (volgers genoemd), drie adviseurs uit de Proeftuin, twee adviseurs buiten de Proeftuin en een loonwerker geïnterviewd. Van de totaal 10 pilot en 87 volgerboeren hebben 57 een enquête ingevuld. De resultaten zijn bediscussieerd met het projectteam en gebruikt voor een brede reflectie en het doen van aanbevelingen.

\section{Belangrijkste maatregelen}

Het toepassen van ammoniak reducerende maatregelen is tijdens de proeftuin periode (2016 - 2018) volgens de respons van de geênqueteerde veehouders als volgt toegenomen:

1. Minder jongvee aanhouden: van $14 \%$ naar $88 \%$

2. Meer beweiden:

3. Mest uitrijden bij gunstig weer: van $49 \%$ naar $72 \%$

4. Mest verdund uitrijden: van $16 \%$ naar $76 \%$

5. Minder eiwit in het gras winnen: van $25 \%$ naar $95 \%$

6. Minder eiwit in het rantsoen: van $4 \%$ naar $49 \%$ van $9 \%$ naar $79 \%$

Door het nemen van deze maatregelen is de ammoniakemissie in 2018 t.o.v. 2015 gemiddeld bij alle deelnemers met bijna 22\% (voorlopige indicatie projectteam) gereduceerd. De bijdrage komt bijna geheel via de veldmaatregelen. Via voedingsmaatregelen is in de praktijk geen of nauwelijks winst geboekt gelet op minimale gerealiseerde verschillen in RE/KVEM, RE in het rantsoen en ureum en TAN in melk tussen de jaren 2015 t/m 2017 (voorlopige cijfers). Blijkbaar probeert men wel minder eiwit te voeren, maar lukte dat niet.

\section{Belangrijkste invloedfactoren}

De RESET methode is gebruikt om de invloedfactoren te duiden, namelijk: Regels, Educatie, Sociale druk, Economie en Tools. Per maatregel zijn deze samengevat in onderstaand schema.

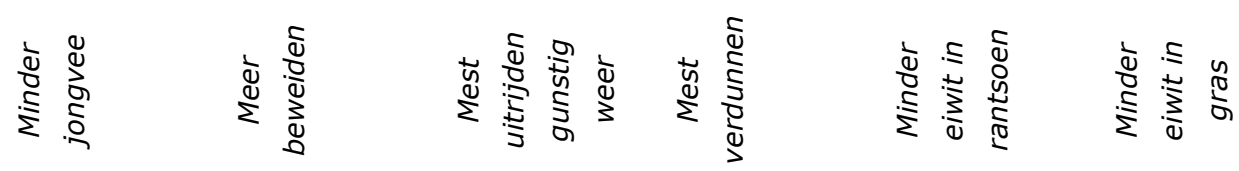

\begin{tabular}{|c|c|c|c|c|c|c|}
\hline Regels & +++ & & & & & \\
\hline Sociale druk & & + & ++ & + & ++ & + \\
\hline Economie & ++ & +++ & + & +++ & & \\
\hline Tools & & & + & + & + & \\
\hline
\end{tabular}

Aanvullend op dit schema zijn belangrijke stimulansen geweest:

- $\quad$ Uitleg waarom ammoniak emissie beperkt moet worden motiveert (geeft urgentie aan). Regels werken beter voor volgerboeren om maatregelen te nemen dan voor pilotboeren. Pilotboeren kijken zelf voldoende vooruit en anticiperen tijdig op aankomende regelgeving.

- Groepsbijeenkomsten waarbij onderzoek en praktijk elkaar ontmoeten werken qua educatie het beste. Het is efficiënt, omdat het minder tijd vergt dan individuele begeleiding, en het is effectief door de interactie. Het geeft inzicht in de mogelijkheden / grenzen qua vaktechnische bedrijfsvoering. Pilotboeren willen vooral gecoacht worden en volgerboeren willen advies op maat. Een mix van communicatieactiviteiten is nodig om een brede groep te bereiken. Elke kennisbron heeft daarbij zijn eigen kracht en valkuil om alert op te zijn. 
- Sociale druk is complex. Adviseurs zorgen voor sociale druk bij volgerboeren; pilotboeren anticiperen op sociale druk vanuit de maatschappij.

- De maatregelen minder jongvee, meer beweiden en mest verdunnen zijn relatief makkelijk te stimuleren, omdat melkveehouders er economisch voordeel van zien.

- Maken van bedrijfsplannen (Tools) die aangeven wat mogelijk is qua reductie binnen (stal) en buiten (veld) werkt stimulerend naar melkveehouders en adviseurs.

Hoe is het gedrag bij een grote groep te sturen om de ammoniakemissie te reduceren? Het gaat om een combinatie van invloedfactoren om veel impact te bereiken. Belangrijk zijn:

1. Aansluiten bij integraal denkkader melkveehouders (regels, educatie en tools) Zowel wetgeving als oplossingsrichtingen moeten integraal een bijdrage leveren aan meerdere bedrijfsdoelen. Geef duidelijk aan waar maatregelen meerdere doelen versterken of waar ze strijdig zijn. Probeer maatregelen aan te laten sluiten op de vaktechnische drive van zowel pilot- als volgerboeren. Dit vergt integraal inzicht in bemesting, graslandmanagement, voeding, diergezondheid, gewasproductie /- kwaliteit en melkproductie.

2. Zorg voor interactie (educatie) Groepsbijeenkomsten werken goed, maar moeten wel afgestemd worden op de doelgroep. Een masterclass bijvoorbeeld voor pilotboeren moet anders ingevuld (meer inspirerend) worden, dan voor volgerboeren (meer adviserend).

3. Aansluiten bij kennisniveau melkveehouders en met de juiste toon (educatie) De mix van communicatieactiviteiten heeft goed gewerkt, denk aan groepsbijeenkomsten, leren van experimenten, individuele begeleiding van pilotboeren, nieuwsberichten en apps. Belangrijk is wel de juiste toon te zetten, zodat 'wrijving inderdaad meer glans oplevert'. De kunst is melkveehouders assertiever / kritischer te maken naar adviseurs en zichzelf. De vaktechnische drive wordt aangewakkerd als melkveehouders de tijd nemen voor het waarnemen met eigen ogen, neus en oren en door gebruik te maken van analyses van bodem, voer en gras.

4. Sociale druk Pilotboeren zijn zich erg bewust van de maatschappelijke druk op de veehouderij en spelen er vanuit hun eigen drive tijdig op in. Volgerboeren doen dit minder en hebben meer druk van buitenaf (adviseurs) nodig om te veranderen.

5. Stimuleer investeren in machines en mestopslag (economie)

Stimuleer voldoende mestopslag en machines om mest aan te wenden op het gewenste tijdstip. Voldoende capaciteit vergoot de flexibiliteit om beter in te spelen op het weer. Beloon door geven van ontwikkelruimte (experimenteren, uitbreiding, risico's afdekken).

6. Maak zowel simpele als meer diepgaandere tools (tools)

De Kringloopwijzer geeft veel inzicht en motiveert, mits die aansluit bij het denkkader van de melkveehouder en de bedrijfsomstandigheden. Sommigen hebben behoefte aan simpele tools en anderen willen meer diepgaande tools. Meer diepgaand betreft: ook planning (kunnen simuleren), tussenresultaten en verschillen tussen percelen tonen. Kansenkaarten zijn in ontwikkeling om link te leggen met regionale water- en natuuropgaven.

\section{Kennisinfrastructuur}

1. Meer regie door de Zuivel in samenwerking met de overheid

Om brede impact te creëren is het belangrijk dat de Zuivelindustrie hun aanpak van beloning duurzame melkveehouderij voortzet. De doelen van het Ministerie zouden hier meer op afgestemd moeten worden en vertaald naar bedrijfsniveau met duidelijke definities / kengetallen. Commitment is nodig van vooral de mengvoerindustrie.

2. Interactie tussen spelers in de kennisinfrastructuur Interactie tussen onderzoek, adviseurs, melkveehouders en beleid dient versterkt te worden om veel impact te creëren. Een mix van experimenten bij melkveebedrijven en proefbedrijf en een variatie aan communicatie activiteiten werkt goed als elke partij zijn rol goed invult. Het levendig houden van de kennisuitwisseling vergt veel inzet. Plannen doorrekenen, monitoren van resultaten en evalueren van maatregelen vergt een actieve inzet van betrokken partijen die elkaar versterken door data, kennis, tools, ervaringen en beleid met elkaar te delen.

Tot slot: Weten waarom en wat er mogelijk is stimuleert alle spelers in het kennisnetwerk. 


\section{Synthese en reflectie}

\section{Inleiding}

Dit hoofdstuk is een uitgebreide samenvatting die de samenhang aangeeft tussen de belangrijkste resultaten en de aanbevelingen voor het creëren van verandering. Het doel van het onderzoek was te ontdekken welke factoren een rol spelen om wel of niet bepaalde maatregelen te nemen om de ammoniakemissies te beperken door melkveehouders in samenwerking met adviseurs en loonwerkers. Het gaat erom de gedragsverandering bij deze doelgroepen te analyseren en te duiden door te onderzoeken wat motiveert en belemmert om maatregelen wel of niet in de praktijk toe te passen. Dit is gedaan in het kader van het project Proeftuin Veenweiden, met 10 pilot- en 87 volgerboeren. Een project biedt echter geen continuïteit. Daarom zijn ook aanbevelingen gedaan over hoe je een grotere groep kunt motiveren tot verandering zonder dat altijd sprake is van een project, maar sprake is van een hechtere band tussen partijen in de kennisinfrastructuur.

Er zijn drie methoden toegepast om gedragsverandering te analyseren, namelijk interviews bij een steekproef van pilotboeren en boeren die deelnemen in de ontwikkelteams (volgers genoemd), een enquête onder alle deelnemende melkveehouders uit de Proeftuin Veenweiden en interviews bij enkele begeleiders, adviseurs (binnen en buiten de proeftuin) en een loonwerker. De interviews betroffen een kwalitatieve analyse en de enquête betrof een kwantitatieve analyse, die inzicht geeft in hoe vaak en hoe een bepaalde ammoniak reducerende maatregel is toegepast en welke prikkels een rol hebben gespeeld om de maatregel te nemen. De resultaten zijn ook besproken met het projectteam, die discussie is meegenomen in dit hoofdstuk 'Synthese en reflectie'.

De aanbevelingen zijn gebaseerd op de RESET methode die onderscheid maakt in vijf gebieden van gedragsverandering, namelijk:

- Regels; regels en wetten leiden tot verplichten en zorgen voor externe motivatie.

- Educatie; door te begrijpen hoe iets zit zorgt voor interne motivatie.

- Sociale druk; door elkaar normen en waarden op te leggen wil je niet buiten de boot vallen.

- Economische prikkels; beïnvloeden kosten en opbrengsten door bonus of boete.

- Tools; zij maken het makkelijker bepaalde maatregelen te nemen.

De factoren die stimuleren en belemmeren verschillen per type melkveehouder. Daarom wordt eerst ingegaan op deze verschillen, vervolgens worden per milieu maatregel de motieven toegelicht om deze wel of niet te nemen, dan wordt aangegeven wat melkveehouders belemmert voor gedragsverandering en tot slot worden aanbevelingen gedaan hoe je gedragsverandering kunt stimuleren. Bij elk onderdeel is reflectie door het projectteam weergegeven.

\section{Typering van de melkveehouders}

De motivatie van de geïnterviewde melkveehouders voor deelname aan de Proeftuin verschilde tussen pilot- en volgerboeren. Bij de pilotboeren speelt het zoeken naar nieuwe uitdagingen c.q. nieuwe dingen leren/uitproberen een belangrijke rol. Bij volgerboeren is de motivatie meer dat men wil leren van het project en men wil leren wat de impact is die ammoniakemissie kan gaan hebben op de bedrijfsvoering. In tabel A staan verschillende kenmerken van pilot- en volgerboeren zoals uit de interviews met de veehouders en adviseurs naar voren zijn gekomen. 
Tabel A Kenmerken van pilot- en volgerboeren in de Proeftuin Veenweiden.

\begin{tabular}{|c|c|}
\hline Pilotboeren & Volgerboeren \\
\hline Zien regelgeving op tijd aankomen & Komen in beweging door wetgeving \\
\hline Zoeken uitdagingen, willen nieuwe dingen leren & $\begin{array}{l}\text { Willen leren van het project en weten wat de impact van } \\
\text { ammoniakemissie op de bedrijfsvoering kan zijn }\end{array}$ \\
\hline Grote intrinsieke motivatie om te veranderen & Veel variatie in mate van veranderingsgezindheid \\
\hline $\begin{array}{l}\text { Kijken meer vooruit, weten waar ze naartoe willen met hun } \\
\text { bedrijf }\end{array}$ & $\begin{array}{l}\text { Kijken minder vooruit, meer gericht op de dagelijkse } \\
\text { bedrijfsvoering }\end{array}$ \\
\hline Willen gecoacht worden & Willen geadviseerd worden \\
\hline Letten sterk op regionale kansen & Focus meer op $\mathrm{P}$ dan op $\mathrm{N}$ \\
\hline Willen grenzen verkennen, maar niet overschrijden & Willen weten waar grens ligt \\
\hline \multicolumn{2}{|c|}{ Gemeenschappelijk } \\
\hline
\end{tabular}

De pilot- en volgerboeren hebben gemeenschappelijk dat ze veel voldoening halen uit 'als het (technisch / economisch) lekker/goed gaat op het bedrijf', blijkt uit de interviews. Dit wordt ondersteund door de resultaten van de enquête waarin de veehouders aangeven een hoge levensduur van het vee en een hoge mineralenefficiëntie van het bedrijf en bodem belangrijk te vinden. Om melkveehouders te stimuleren maatregelen te nemen die de ammoniakemissie verminderen, moeten die aansluiten bij deze vaktechnisch gerichte interne motivatie. En beide typen melkveehouders hebben behoefte aan een geïntegreerd plan. Dat geldt ook voor wetgeving, want de meeste zorgen krijgt men van (onberekenbare en onduidelijke) regelgeving en de gevolgen daarvan op de bedrijfsvoering. Echter de wijze waarop pilotboeren en volgerboeren omgaan met adviseurs en regelgeving verschilt. Pilotboeren kijken vooruit, spelen tijdig in op aankomende wetgeving, denken vooral in kansen en willen geïnspireerd worden. Zij zijn sterk in het maken van eigen keuzes en inspireren ook anderen, terwijl volgerboeren meer duidelijkheid op maat willen qua wetgeving en advies. De variatie in volgerboeren is echter groot. Verwacht mag worden dat het grote peloton meer overeenkomt met de typering van volgers.

\section{Reflectie vanuit Projectteam}

- $\quad$ Overheid: sluit de regelgeving aan op de motivatie van de boeren; dat betekent enerzijds aansluiten op de vaktechnische drive (managementkengetallen) en anderzijds heldere regelgeving.

- Boeren: als je onwelkome regelgeving wilt voorkomen moet je zelf aan de slag gaan vanuit je eigen motivatie en goed presteren. Dit blijkt voor pilotboeren makkelijker dan voor volgerboeren.

- Adviseurs: sluit aan op interne motivatie van melkveehouders; maak hierbij onderscheid tussen behoefte aan coachen en adviseren.

\section{Toepassing van ammoniak reducerende maatregelen}

In tabel B wordt het overzicht gegeven van een zestal maatregelen die zijn toegepast in de Proeftuin Veenweiden door de pilot- en volgerboeren om de ammoniakemissie te reduceren.

Tabel B Toepassing van ammoniakreducerende maatregelen tijdens het project 'Proeftuin Veenweiden' in 2017 en 2018 o.b.v. opgave door de geënquêteerde veehouders.

\begin{tabular}{lccc} 
Maatregel & $<2017$ & 2017 & 2018 \\
Minder jongvee & $14,0 \%$ & $54,4 \%$ & $87,7 \%$ \\
\hline Meer beweiden & $49,1 \%$ & $17,5 \%$ & $71,9 \%$ \\
\hline Mest uitrijden bij gunstig weer & $15,8 \%$ & $57,9 \%$ & $75,5 \%$ \\
\hline Mest verdunnen & $24,5 \%$ & $61,4 \%$ & $94,7 \%$ \\
\hline Minder eiwit in rantsoen & $8,8 \%$ & $56,1 \%$ & $79,0 \%$ \\
\hline Minder eiwit in gras & $3,5 \%$ & $28,1 \%$ & $49,1 \%$ \\
\hline
\end{tabular}

Het blijkt dat mest verdunnen het meest is toegepast $(94,7 \%)$, echter bijna een kwart $(24,5 \%)$ deed dit ook al voor de start van het project. Vooral de maatregelen om minder eiwit te voeren, o.a. door minder eiwit in het gras, zijn sterk toegenomen in de projectperiode 2017 en 2018 . Ook mest uitrijden bij gunstig weer is een belangrijke maatregelen die steeds meer is toegepast. 


\section{Reflectie vanuit Projectteam}

- De belangrijkste maatregelen om ammoniakemissie te beperken zijn in volgorde van prioriteit: minder eiwit in het rantsoen, meer beweiden en mest verdund uitrijden bij gunstig weer.

- Door het nemen van deze maatregelen is de ammoniakemissie in 2018 t.o.v. 2015 gemiddeld bij alle deelnemers met bijna 22\% (voorlopige indicatie projectteam) gereduceerd. De bijdrage komt bijna geheel via de veldmaatregelen (beweiden en verdund uitrijden bij gunstig weer). Via voedingsmaatregelen is geen of nauwelijks winst geboekt gelet op minimale verschillen in RE/KVEM, RE in het rantsoen en ureum en TAN in mest tussen de jaren 2015 $\mathrm{t} / \mathrm{m} 2017$ (voorlopige cijfers). Blijkbaar probeert men wel minder eiwit te voeren, maar lukt het niet om deze daadwerkelijk door te voeren.

- De capaciteit van de melkveehouder of de loonwerker bepaalt in sterke mate of mest uitrijden bij gunstig weer lukt.

De motivatie om een maatregel wel of niet toe te passen wordt per maatregel toegelicht. Eerst wordt de uitslag van de enquête weergegeven en hier en daar aangevuld met opmerkingen uit de interviews, en vervolgens de reflectie vanuit de Proeftuin.

\section{Minder jongvee}

Tijdens het project gaf bijna 74\% van de geënquêteerde veehouders aan minder jongvee te zijn gaan aanhouden. In tabel $\mathrm{C}$ staan de drie belangrijkste redenen waarom men wel/niet minder jongvee is gaan aanhouden.

Tabel C De drie belangrijkste redenen om wel/niet minder jongvee aan te gaan houden.

\begin{tabular}{llll} 
Waarom wel & & Waarom niet \\
Verminderen van de fosfaatproductie op het bedrijf & $36 \%$ & Men al weinig jongvee aan hield & $53 \%$ \\
\hline Het nastreven van een lange levensduur van het vee & $36 \%$ & Men ruwvoer over had op het bedrijf & $27 \%$ \\
\hline Vanwege fosfaatrechten. & $17 \%$ & Men geen jongvee aanhield op het bedrijf & $13 \%$ \\
\hline
\end{tabular}

De belangrijkste motivatie om minder jongvee te gaan aanhouden is het verlagen van de fosfaatproductie, en niet zozeer om de ammoniakemissie te verminderen. Van de melkveehouders die minder jongvee zijn gaan aanhouden verwacht ruim de helft de komende jaren hetzelfde aantal stuks jongvee per 10 melkkoeien aan te blijven houden.

\section{Reflectie vanuit Projectteam}

- $\quad$ Minder jongvee om ammoniak te reduceren lift vooral mee op de fosfaatwetgeving en de economische drive om minder dieren op te fokken.

- Minder jongvee betekent niet automatisch minder ammoniakemissie. Om dit wel te realiseren is gericht voermanagement nodig. Indien minder P-productie door jongvee gecompenseerd wordt door meer melkkoeien levert dit geen ammoniakreductie op. De gevolgen voor de veldemissie door minder jongvee bij gelijke aantal melkkoeien is complexer, omdat gehele bedrijfsvoering gaat veranderen inclusief het rantsoen van melkvee en of sprake is van mestafzet. Bij minder mestafzet door minder jongvee is er immers nog geen minder ammoniakemissie op het bedrijf, want er wordt evenveel mest uitgereden op het eigen bedrijf. Rantsoen van melkvee kan veranderen doordat eiwitrijk gras wat eerst gevoerd werd aan jongvee nu gevoerd wordt aan melkvee.

\section{Meer beweiden}

Tijdens het project gaf bijna $23 \%$ van de veehouders aan nog meer te gaan beweiden. Dit is weliswaar een beperkte toename, maar bijna de helft van de veehouders gaf aan dat ze al voor het begin van proeftuin de koeien veel lieten weiden. In tabel $D$ staan de drie belangrijkste redenen waarom men wel/niet meer is gaan beweiden. 
Tabel D De drie belangrijkste redenen om wel/niet meer te gaan beweiden.

\begin{tabular}{llll} 
Waarom wel & & Waarom niet & \\
Men een lage kostprijs wil realiseren & $39 \%$ & Men al maximaal probeert te beweiden & $53 \%$ \\
\hline Men veel melk uit vers gras wil produceren & $31 \%$ & De huiskavel te klein is & $27 \%$ \\
\hline Anders & $31 \%$ & Men de koeien jaarrond op stal wil houden & $7 \%$ \\
\hline & & Men melkt met een robot & $7 \%$ \\
\hline
\end{tabular}

De motivatie om meer te gaan beweiden ligt vooral in de reden dat men een lage kostprijs wil realiseren en men veel melk uit gras wil produceren. Volgens de adviseurs doen veehouders vooral de koeien eerder naar buiten, en of men langer doorweidt hangt vooral af van de weersomstandigheden. Van de melkveehouders die meer zijn beweiden verwacht ruim driekwart dat ze de komende jaren meer dan in 2016 blijven beweiden, terwijl de rest het nog niet weet.

\section{Reflectie vanuit Projectteam}

- Economie is een belangrijke drive voor meer beweiden, hierbij is de reductie in ammoniakemissie mooi meegenomen volgens de adviseurs.

- De laatste jaren komt ook steeds meer kennis over beweiden, vooral in combinatie met melkrobot(s) en bij grote veestapels. Het blijkt landelijk dat aantal nieuwe weiders toeneemt.

- Onderwaterdrainage helpt het weideseizoen te verlengen, echter boeren zijn terughoudend door de hoge investering die dit vergt.

\section{Mest uitrijden bij gunstig weer}

Tijdens het project gaf $60 \%$ van de veehouders aan mest te zijn gaan uitrijden onder gunstige weersomstandigheden. In tabel E staan de drie belangrijkste redenen waarom men wel/niet mest is gaan uitrijden onder gunstige weersomstandigheden.

Tabel $\boldsymbol{E} \quad$ De drie belangrijkste redenen om wel/niet mest uit te gaan rijden bij gunstig weer.

\begin{tabular}{llll} 
Waarom wel & & Waarom niet & \\
Men flexibel is met eigen bemestingsapparatuur & $44 \%$ & Men dit al deed voor 2017 & $35 \%$ \\
\hline Men wacht op goede weersomstandigheden & $32 \%$ & De loonwerker is niet altijd beschikbaar & $30 \%$ \\
\hline De loonwerker over voldoende capaciteit beschikt & $21 \%$ & De weersomstandigheden te wisselvallig zijn & $26 \%$ \\
\hline
\end{tabular}

Van de melkveehouders die de mest uitrijden onder gunstige weersomstandigheden verwacht ruim driekwart dat ze dit de komende jaren blijven doen. Volgens de adviseurs spelen bij het mest uitrijden onder gunstige weersomstandigheden twee factoren een belangrijke rol: heeft men wel/niet een eigen bemester en heeft men wel/niet voldoende opslagcapaciteit. Boeren die een eigen bemester hebben, kunnen makkelijker onder gunstige weersomstandigheden uitrijden dan boeren die afhankelijk zijn van de loonwerker. Veehouders die zelf uitrijden houden dan ook meer rekening met het weer. Echter steeds minder veehouders hebben een eigen bemester vanwege de hoge kosten van deze machines, waardoor uitrijden onder gunstige omstandigheden steeds moeilijker wordt. Bij een deel van de boeren is de (beperkte) opslagcapaciteit leidend voor het moment van mest uitrijden. Aan het eind van het uitrijseizoen moeten de mestopslagen leeg zijn om de winterperiode te kunnen overbruggen. En aan het begin van het uitrijseizoen moet zodra het weer en het land het toelaat mest worden uitgereden omdat de mestopslagen vol zitten. Bovendien moeten loonwerkers hun werkzaamheden rond mest uitrijden spreiden, omdat ze niet altijd over voldoende capaciteit (machines) beschikken om alle mest van hun klanten onder gunstige weersomstandigheden uit te rijden.

\section{Reflectie vanuit Projectteam}

- $\quad$ Capaciteit van de melkveehouder en de Loonwerker qua machines en mestopslag bepaalt sterk of men in kan spelen op weersomstandigheden.

- Berijdbaarheid / draagkracht van het land speelt ook een belangrijke rol om tijdig mest uit te rijden, investeren in onderwaterdrainage vergroot de flexibiliteit.

- $\quad$ Een app die het beste moment aangeeft voor mest uitrijden, rekening houdend met voorspelling van het weer kan helpen, maar zal voor boeren ook belerend overkomen. De huidige app is gebruikt door de pilotboeren. De app zal verfijnd worden door meer rekening te houden met draagkracht bodem, bodem temperatuur en weersvoorspelling. 


\section{Verdund mest uitrijden}

Tijdens het project gaf ruim $70 \%$ van de veehouders aan mest verdund te zijn gaan uitrijden. In tabel F staan de drie belangrijkste redenen waarom men wel/niet mest is verdund gaan uitrijden.

Tabel $\boldsymbol{F} \quad$ De drie belangrijkste redenen om wel/niet mest verdund uit te gaan rijden.

\begin{tabular}{lcll} 
Waarom wel & & Waarom niet \\
Het een betere benutting van de mineralen geeft & $50 \%$ & Men al mest verdund uitrijdt \\
\hline Geeft minder stikstofverliezen door minder emissie & $45 \%$ & Uitrijden dan meer tijd en geld kost \\
\hline Anders & $5 \%$ & Men daar de bemestingsapparatuur niet voor heeft. & $6 \%$ \\
\hline & & $\begin{array}{l}\text { Men zelf met de tank uitrijd en een deel drassig } \\
\text { land op afstand heeft. }\end{array}$
\end{tabular}

Alle veehouders die mest verdund zijn gaan uitrijden, verwachten dat ze de komende jaren verdund mest zullen blijven uitrijden. Volgens de adviseurs is dit de belangrijkste maatregel geweest. Deze is met name effectief, omdat het simpel is, goed toepasbaar en veehouders de revenuen ervan zien door een betere grasgroei. Het grootste knelpunt zit hier bij boeren die met een eigen mesttank uitrijden. Verdund uitrijden gaat bij een tank ten koste van de capaciteit en bij vervoer over de weg naar percelen op afstand krijg je te maken met extra transport. Daarentegen laten meer boeren de mest uitrijden door de loonwerker vanwege toename in bedrijfsomvang.

\section{Reflectie vanuit Projectteam}

- Duidelijke regelgeving is van belang opdat Loonwerkers tijdig investeren in de juiste machines en apparatuur (bijvoorbeeld flowmeter als tool) om benodigde verdunning te controleren.

- Melkveehouders zijn vooral economisch gedreven doordat ze betere grasgroei waarnemen, en dus economisch voordeel zien.

- Verdunnen vindt hoofdzakelijk plaats tijdens uitrijden. Loonwerkers geven aan dat mest mengen met slootwater de mest ook beter verpompbaar maakt. Mest verdunnen in de stal doet slechts een enkeling, dit draagt tevens bij aan verminderen stalemissie.

- $\quad$ De verhouding mest : water varieert tussen 1:1, 2:1 en 3:1.

- Mest uitrijden gebeurt het meest met de sleepvoet en soms met sleufkouter.

\section{Minder eiwit in rantsoen}

Tijdens het project gaf ruim $70 \%$ van de veehouders aan het eiwitgehalte in het rantsoen te hebben verlaagd. Dit blijkt overigens niet uit de rantsoenen, en dus moet dit meer gezien worden als een intentie van de melkveehouders. In tabel $\mathrm{H}$ staan de drie belangrijkste redenen of methode waarom of hoe men wel/niet een rantsoen met minder eiwit is (of wilde) gaan voeren.

Tabel $\boldsymbol{H} \quad$ De drie belangrijkste redenen / methoden om wel/niet minder eiwit in het rantsoen te gaan voeren.

\begin{tabular}{llll} 
Waarom wel & & Waarom niet & Men een lagere melkproductie verwacht \\
Meer eiwitarmere voerproducten gaan aankopen & $45 \%$ & Men & $59 \%$ \\
\hline Gras met een lager ruw eiwit is gaan oogsten & $35 \%$ & Zit al laag met ruw eiwit, voer al op de norm & $29 \%$ \\
\hline Meer mais in het rantsoen is gaan voeren & $13 \%$ & Mijn voeradviseur raadt dat af & $2 \%$
\end{tabular}

Van de melkveehouders die minder eiwit in het rantsoen is gaan voeren verwacht bijna tweederde dat ze de komende jaren een rantsoen met minder ruw eiwit blijven voeren. Volgens de adviseurs moet deze maatregel in combinatie gezien worden met minder eiwit in het gras, aangezien het gras een onderdeel van het rantsoen is en mengvoer maar een deel van het totale rantsoen is. Naast verlaging van het ruw eiwitgehalte in het mengvoer, kan men ook een ander soort eiwit in mengvoer gebruiken die beter aansluit bij het OEB en DVE-gehalte van het gewonnen gras. Daarnaast kan men eiwitarmere enkelvoudige grondstoffen gaan voeren. Het ruw eiwitgehalte kan nog omlaag volgens de adviseurs. Echter in het algemeen zijn veevoeradviseurs terughoudend met het voeren van minder eiwit. 


\section{Reflectie vanuit Projectteam}

- Werkelijke cijfers

Minder eiwit voeren blijkt niet uit de volgende voorlopige cijfers van de pilotboeren:

\begin{tabular}{|l|c|c|c|c|}
\hline Rantsoen & $\mathbf{2 0 1 5}$ & $\mathbf{2 0 1 6}$ & $\mathbf{2 0 1 7}$ & $\mathbf{2 0 1 8}$ \\
\hline RE/KVEM totaal rantsoen & 173 & 170 & 174 & 176 \\
\hline RE in krachtvoer & 160 & 160 & 164 & 145 \\
\hline Ureum & 23 & 20 & 22 & 21 \\
\hline TAN-productie / ton melk & 11.7 & 11.2 & 11.7 & 11.7 \\
\hline
\end{tabular}

Er is geen daling in RE totaal rantsoen, in 2018 wel daling RE in krachtvoer en geen daling in ureum en TAN in melk bij de pilotboeren.

- Integrale kennis nodig

Dit is de belangrijkste en moeilijkste maatregel die samenwerking tussen melkveehouders en adviseurs vergt. Tijdens een workshop met adviseurs van de mengvoerindustrie hebben de voeradviseurs namelijk zelf aangegeven dat ze bang zijn dat minder eiwit in het rantsoen ten koste gaat van de melkproductie per koe en daarmee ook hun concurrentiepositie ten opzichte van andere adviseurs in gevaar komt. Adviseurs die geïnterviewd zijn en niet gebonden zijn aan de verkoop van mengvoer en pilotboeren gaven aan dat minder eiwit voeren mogelijk is en cruciaal is voor verminderen ammoniakemissie. Dit vergt integrale kennis van adviseurs of een groep adviseurs / dierenarts over de onderlinge relaties tussen graslandmanagement (weiden en maaien), bemesting, inkuilen, rantsoen, voermethode, diergezondheid en productie. Dit is ook de vaktechnische ondersteuning die de melkveehouders stimuleert.

- Druk nodig

Het is belangrijk dat minder eiwit in het rantsoen de nieuwe norm wordt, net zoals bereikt is met meer beweiden of met een voorbeeld buiten de landbouw van 'niet meer roken'.

- $\quad$ Opleiding jonge adviseurs

Benadrukt is tijdens de interviews dat jonge adviseurs die voeradviezen geven goed geschoold moeten worden in deze integrale aanpak.

- Melkveehouders zouden minder afhankelijk kunnen worden van voeradviseurs als er onafhankelijke tools beschikbaar komen die hen ondersteunen bij de technisch / economische / milieukundige afweging

Minder eiwit in gras

Tijdens het project gaf ruim 45\% van de veehouders aan gras met minder eiwit te zijn gaan winnen. In tabel $\mathrm{G}$ staan de drie belangrijkste redenen of methode waarom of hoe men wel/niet gras met minder eiwit is gaan winnen.

Tabel G De drie belangrijkste redenen / methoden om wel/niet minder eiwit in het gras te gaan winnen.

\begin{tabular}{llll} 
Waarom wel & & Waarom niet \\
Men minder kunstmest is gaan strooien & $58 \%$ & Wil zoveel mogelijk ruw eiwit van eigen land halen & $42 \%$ \\
\hline Men later is gaan maaien & $15 \%$ & De hoge stikstofmineralisatie op mijn grond & $29 \%$ \\
\hline Men minder eiwit en meer structuur wil voeren & $12 \%$ & Men liever het rantsoen stuurt via aangekocht voer & $7 \%$ \\
\hline
\end{tabular}

Van de melkveehouders die gras met minder eiwit is gaan winnen, verwacht bijna tweederde dat ze de komende jaren gras met minder ruw eiwit blijven winnen. Volgens de adviseurs is minder eiwit in het gras een maatregel die altijd in combinatie moet worden gezien met het eiwitgehalte in het rantsoen. Er liggen mogelijkheden om het ruw eiwitgehalte in het gras te verlagen waarbij rekening dient te worden gehouden met grasproductie en graskwaliteit. Om een lager eiwitgehalte in het gras te krijgen hoeft niet al het gras een laag eiwitgehalte te hebben. Het gaat erom dat je gemiddeld goed in het rantsoen met een lager eiwitgehalte toe kan. Een lager eiwitgehalte in het gras kan worden bereikt door later te maaien en/of minder/anders te bemesten. Later maaien spreekt boeren minder aan vanwege risico's op slechter weer, kans op ondergras en naast een lager RE-gehalte ook een lager VEM-gehalte. Lager ruw eiwitgehalte in het gras wordt in de praktijk vooral bereikt door minder kunstmestgebruik. 


\section{Reflectie vanuit Projectteam}

- In bedrijfsverband

Minder eiwit in het gras moet geen doel op zich zijn, omdat het ook moet passen in het totale rantsoen en dat je 2/3 eiwit van eigen land voert. Bovendien is het lastig te sturen doordat het stikstofleverend vermogen van veengrond erg kan variëren.

- Onderwaterdrainage Onderwaterdrainage kan mogelijk helpen het eiwitgehalte in het gras te stabiliseren, zodat betere sturing van het rantsoen mogelijk is.

\section{Motieven en kennisbronnen voor gedragsverandering}

\section{Motieven}

Verschillende ondernemers hebben verschillende motieven voor gedragsverandering. Volgens de RESET-methode zijn er vijf gebieden om gedragsveranderingen te stimuleren, namelijk regels, educatie, sociale druk, economische prikkels en tools. In tabel I staan de tien belangrijkste en vijf minst belangrijke invloedfactoren die volgens de geënquêteerde melkveehouders van belang voor hen zijn geweest om ammoniak reducerende maatregelen te nemen.

Tabel I Belangrijkste en minst belangrijkste invloedfactoren om ammoniak reducerende maatregelen te nemen volgens de geënquêteerde veehouders (Top 10: $1=$ meest belangrijk, vervolgens afnemend belangrijkheid; Laagste 5: 1 = meest onbelangrijk, vervolgens afnemend minder belangrijk).

\begin{tabular}{|c|c|c|c|}
\hline & Invloedfactor & Top 10 & Laagste 5 \\
\hline \multirow[t]{2}{*}{$\mathrm{R}$} & Regelgeving landelijke overheid (nu en toekomst) & 6 & \\
\hline & Regelgeving vanuit de melkfabriek (nu en toekomst) & $10+11$ & \\
\hline \multirow[t]{4}{*}{$\mathrm{E}$} & Masterclasses van Proeftuin Veenweiden & 1 & \\
\hline & Groepsbijeenkomsten met boeren uit de Proeftuin Veenweiden & $3+4$ & \\
\hline & Eigen testen op het bedrijf & 7 & \\
\hline & Open dag bij een boer & & 4 \\
\hline \multirow[t]{4}{*}{$\mathrm{S}$} & Begeleider van Proeftuin Veenweiden & $3+4$ & \\
\hline & Advies van de accountant & & 1 \\
\hline & Bericht op sociale media (o.a. twitter, Facebook) & & 2 \\
\hline & De loonwerker & & 3 \\
\hline $\mathrm{E}$ & Berekend economisch voordeel & 9 & \\
\hline
\end{tabular}

De top 5 van invloedfactoren die melkveehouders stimuleren om hun gedrag te veranderen zijn kennis opdoen tijdens Masterclasses en groepsbijeenkomsten (Educatie), ondersteuning van de groepsbegeleider, en leren van eigen waarnemingen ondersteund door analyses van voer, bodem en gras (Tools). Uit de enquête blijkt dat de drie minst belangrijk invloedfactoren onder sociale druk vallen, namelijk advies van de accountant, sociale media en de loonwerker. Ook bezoek van een open dag bij een collega boer is geen belangrijke factor geweest om ammoniak reducerende maatregelen toe te passen.

Toch lijkt de sociale druk belangrijker dan blijkt uit de uitslag van de enquête. Uit de interviews met de melkveehouders blijkt namelijk dat persoonlijke contacten belangrijke beïnvloeders zijn: familie, collega melkveehouders, adviseurs en studieclubs. Echter er bleek ook een grote variatie te zijn waardoor boeren zich laten beïnvloeden. De één wordt wel beïnvloed door zijn vrouw, terwijl bij een ander dat niet het geval is. Bij één is de onafhankelijke adviseur belangrijk, terwijl bij een ander de voeradviseur dat is. Bij collega melkveehouders zijn het regelmatig specifieke boeren waarmee ze zaken bespreken of spiegelen. Overigens blijken ook (onafhankelijke) adviseurs vaak inspiratie op te doen bij andere specifieke adviseurs. Een jonge ondernemer gaf aan dat het ook lef vraagt om los te komen van inzichten van de vorige generatie, vooral als dat niet overeenkomt met wat ze tijdens de opleiding hebben geleerd. 


\section{Kennisbronnen}

De drie belangrijkste kennisbronnen voor de geënquêteerde melkveehouders waren studiegroep, vakbladen en de adviseur van de voerfabriek. Elke kennisbron heeft zijn eigen geschiktheid (rol) en valkuil in het kennisnetwerk. In tabel J zijn opvattingen uit interviews samengevat.

Tabel J Geschiktheid en valkuil per kennisbron.

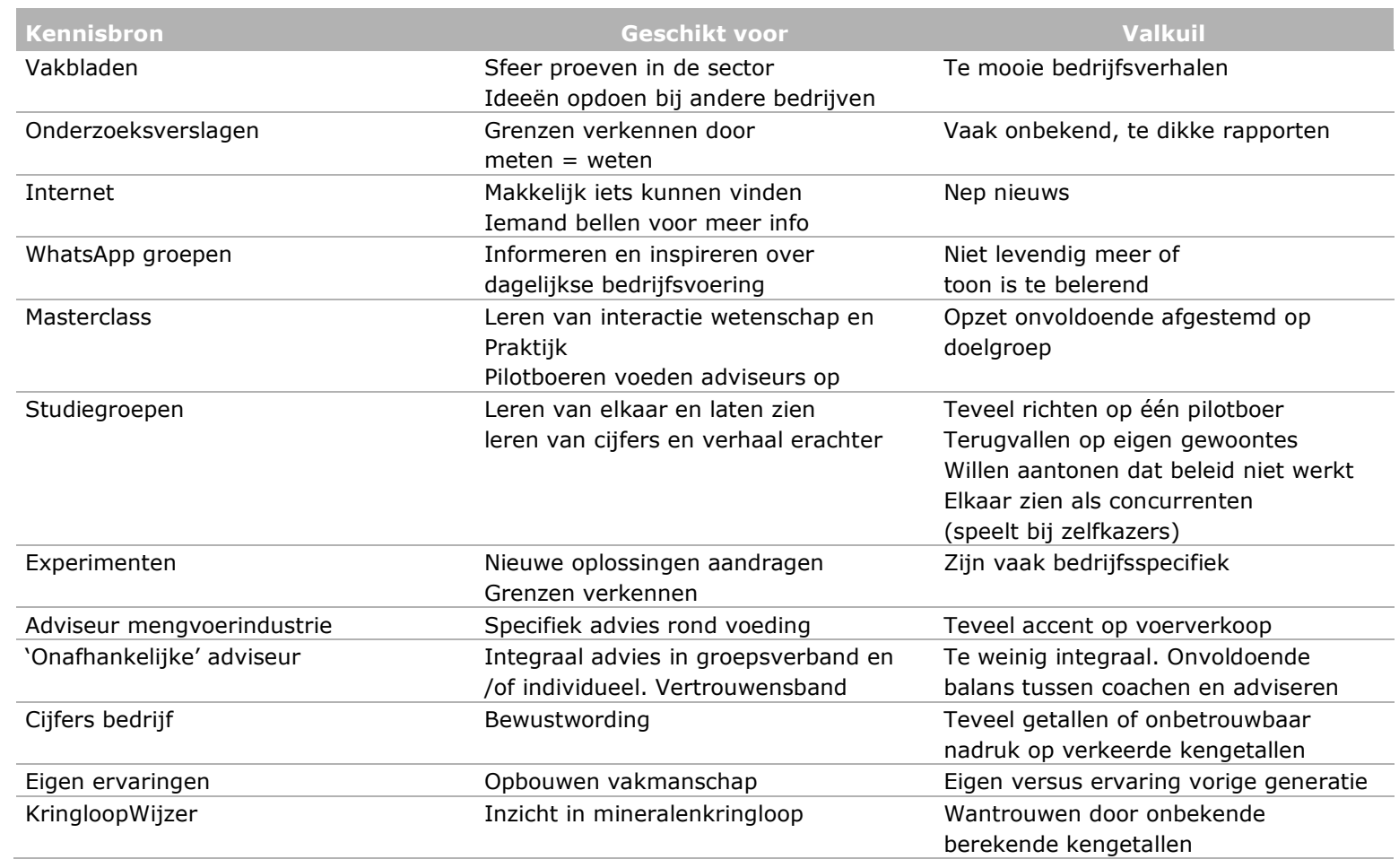

In dit project is het belangrijk grenzen te verkennen qua scherpte van voeren en bemesten. Hoe ver kun je terug in de kunstmestgift en welk soort kunstmest, hoe benut je mest optimaal en hoe ver kun je terug in eiwitgehalte en soort eiwit in het rantsoen? Het vergt lef deze grenzen te verkennen; deze rol is vooral weggelegd voor onderzoek / experimenten doen op proef- en/of praktijkbedrijven. Een pilotboer zei het treffend: "Je weet pas waar de grens ligt als je erover heen gaat". Zowel pilot- als volgerboeren zijn terughoudend in het verkennen van die grenzen, omdat het risico's kan geven zoals minder grasproductie of dat maatregelen ten koste gaan van de diergezondheid. Bedrijfsverhalen met een goede onderbouwing met cijfers kunnen inspirerend zijn, maar de valkuil is dat ze ook te mooi voorgespiegeld kunnen worden. Cijfers van eigen bedrijf van analyses (voer, bodem, gras) en kengetallen uit kringloopwijzer kunnen helpen inzicht te geven in de bedrijfsvoering. Belangrijk daarbij is te sturen op de juiste kengetallen. Voor velen blijkt veel melk uit gras een belangrijk kengetal, anderen geven aan dat je niet moet sturen op Melk / P, maar op VEM / P of RE / KVEM verhouding. Adviseurs van de Mengvoerindustrie letten vooral op productie per koe, terwijl 'onafhankelijke' adviseurs en melkveehouders, vooral pilotboeren, meer focussen op meerdere integrale thema's als diergezondheid, levensduur en economie. Bij de opzet van groepsbijeenkomsten wordt aangegeven dat het belangrijk is te letten op het kennisniveau van de groep, of er sprake kan zijn van onderlinge concurrentie of met welke intentie men deelneemt (aantonen wat kan of wat niet kan). Voor adviseurs is het belangrijk een goede vertrouwensband met de melkveehouder op te bouwen en weten of je meer moet coachen of advies op maat moet geven. Ook kiezen bepaalde adviseurs bewust voor groepsbijeenkomsten in plaats van individuele begeleiding, om redenen van efficiëntie (individuele begeleiding is duur) en effectiviteit (in groep meer interactie). 


\section{Belemmeringen}

Uit de interviews en enquête komen punten naar voren die gedragsverandering belemmeren. Deze signalen zijn belangrijk om te weten hoe je deze kunt omzetten in stimulerende factoren.

\section{Regelgeving is teveel middelgericht en niet integraal op bedrijfsniveau}

Het uitsluiten van bepaalde mestaanwending technieken is een voorbeeld dat het beleid teveel gericht is op het middel en te weinig op het doel om betere $\mathrm{N}$-benutting te realiseren. Daarmee loop je risico dat er te weinig aandacht is voor integrale aanpakken en dat met name innovatieve boeren zich belemmerd voelen in het verkennen van nieuwe richtingen. Denk bijvoorbeeld aan melkveehouders die experimenteren met andere mestsoorten; stromest of scheiden van feces en urine. Ook voelen individuele boeren zich niet aangesproken door sectordoelen, dat is een probleem van de sector en niet van mij. Wanneer het beleid (EU, landelijk en regionaal) onduidelijk is voor de eigen bedrijfssituatie en veel administratie vergt werkt dit demotiverend.

\section{Advisering is niet integraal en te belerend}

Het werkt erg demotiverend als maatregelen gericht op het verminderen van de ammoniakemissie strijdig zijn met maatregelen om de emissie van broeikasgassen te verminderen (voor zover dat bekend is, wat niet altijd het geval is). Bijvoorbeeld later maaien geeft meer structuur en minder eiwit in de kuil en kan daardoor de ammoniak emissie beperken, echter meer ruwe celstof in het rantsoen kan de emissie van methaan verhogen. Ook kan er discrepantie zijn tussen optimaliseren op dier- en bedrijfsniveau. Het kan bijvoorbeeld op dierniveau aantrekkelijk zijn om meer maïs of krachtvoer te voeren, echter op bedrijfsniveau niet. Advisering is niet altijd rechtlijnig van de adviseur naar de melkveehouder. Vaak is sprake van kennisuitwisseling. Pilotboeren vragen bijvoorbeeld adviseurs om minder eiwit te voeren en delen hun eigen ervaringen. Dit vergt onderling vertrouwen. Ook wordt veel kennis over de bedrijfsvoering uitgewisseld via bijvoorbeeld whatsApp groepen of groepsbijeenkomsten. Bij maatregelen als mest uitrijden bij gunstig weer kan een te belerende toon belemmerend werken, omdat melkveehouders met meer zaken in de bedrijfsvoering rekening moeten houden, zoals bijvoorbeeld voldoende mestopslag die niet snel aan te passen is. Niet realistische adviezen of onhaalbare doelen kunnen demotiverend werken.

\section{Veranderingen brengen risico's mee}

Als een bedrijf technisch goed draait is de wil om te veranderen gering, omdat veranderingen risico's en gedoe geven. Bepaalde gewoontes in de bedrijfsvoering kunnen van de ene generatie op de andere generatie overgaan. Dit kan veranderingen doorvoeren ook belemmeren. Vooral als het financiële risico's betreft en er weinig financiële ruimte is voor investeringen, door zowel melkveehouders als loonwerkers, zal men niet snel veranderen tenzij er een beloning tegenover staat. Vooral bij grote investeringen in gebouwen of machines is duidelijkheid in regelgeving nodig, bijvoorbeeld in toegestane mest aanwendingstechnieken of technieken om verdunnen van mest te controleren. Als er dus dan toch op middelen wordt gestuurd in plaats van doelen, dan is ook tijdig duidelijkheid nodig.

\section{Bedrijfsomstandigheden zijn beperkt of onvoldoende hulpmiddelen}

Een te kleine huiskavel, onvoldoende mestopslag, onvoldoende financiële ruimte voor investeringen in bijvoorbeeld machines of onderwaterdrainage kunnen het nemen van milieumaatregelen belemmeren. Ook een tool als de Kringloopwijzer, die bedoeld is ter ondersteuning van de bedrijfsvoering, kan demotiverend werken als de aannames in de berekening van kengetallen onvoldoende aansluiten bij de bedrijfsvoering. De KringloopWijzer leeft weinig in het veenweidegebied, want de meesten hebben geen BEX voordeel. 


\section{Stimulansen / aanbevelingen}

In de vorige paragrafen is toegelicht:

- Welke maatregelen de melkveehouders op welke wijze hebben toegepast.

- Welke kennisbronnen belangrijk zijn, waar ze geschikt voor zijn en welke valkuilen er zijn.

- Welke factoren qua regelgeving, educatie, sociale druk, economie en tools (Reset) belemmerend of demotiverend werken .

In deze paragraaf worden aanbevelingen gedaan wat stimuleert. Educatie, goede begeleiding en eigen ervaringen blijken de belangrijke factoren te zijn die stimuleren de bedrijfsvoering aan te passen. Het aangeven van de urgentie (het moet) en de mogelijkheden (het kan) heeft zowel bij de melkveehouders als de adviseurs stimulerend gewerkt. Het gaat er om een combinatie van alle vijf invloedfactoren (RESET) optimaal in te zetten voor het creëren van impact.

\section{Zuivelindustrie en overheid samen werken aan integrale duurzaamheid (Regels en Educatie)}

De proeftuin veenweiden is gericht op maatregelen om de ammoniakemissie te beperken. Het is sterk aan te bevelen dat de Ministeries en de Zuivelindustrie (Duurzame Zuivelketen) samen werken om verschillende doelen te halen, zodat de concrete maatregelen meer integraal in te vullen zijn en zich richten op concrete bedrijfsdoelen. Het gaat om het realiseren van meerdere duurzaamheid doelen, denk aan verminderen ammoniakemissie, verminderen emissies van broeikasgassen, 65\% eiwit van eigen land, meer grondgebonden, beweiden, langere levensduur vee en specifiek voor het veenweidegebied beperken bodemdaling en natuur inclusieve landbouw. Maatregelen die de efficiëntie van de gewasproductie en melkproductie verbeteren met behoud of verbetering van de diergezondheid zullen melkveehouders aanspreken, omdat ze het werkplezier vergroten en over het algemeen ook het inkomen verbeteren.

\section{Aansluiten bij integraal denkkader van melkveehouders (Regels en educatie)}

Een geïntegreerde aanpak qua huisvesting, graslandmanagement en voeding is in het kader van de doelstelling van Proeftuin veenweiden belangrijk. Dat vergt een brede kennis van (veevoer)adviseurs. Daarbij is sterk behoefte aan het verkrijgen van inzicht in grenzen qua bemesting en voeding waarbij gestuurd wordt op de juiste kengetallen en haalbare doelen. Welke dat precies zijn vergt nadere uitwerking rekening houdend met duurzaamheidsdoelen en bedrijfsomstandigheden en onderverdeeld per bedrijfsonderdeel. De grenzen hebben betrekking op hoeveelheden en kwaliteit, denk aan drijfmest of dikke (feces) en dunne (urine) fracties uit de stal hoe en wanneer uitrijden, spreiding kunstmestgift en soort kunstmest, het samenspel tussen graslandmanagement (soort gras, beweiding, maaistadium), hoeveelheid en soort krachtvoer of bijproducten in relatie tot eiwitproductie eigen land, melk uit gras, $\mathrm{P}$ in mest, diergezondheid, N-benutting, etc. Dit optimaliseren past bij het denken van pilot- en volgerboeren. De uitdaging is dit denken te combineren met verminderen ammoniakemissie en tevens andere duurzaamheid doelen. Een pittige uitdaging. De deelnemers zouden daarom graag voortgang van het project zien gericht op deze nog meer integrale aanpak.

Voor vervolg is het belangrijk met een top 10 maatregelen aan de slag te gaan die integraal werken om de doelen van de Zuivelindustrie en de overheid te bereiken, beperk (of stop zelfs volgens sommige) met factsheets over één onderwerp.

\section{Zorg voor interactie (Educatie)}

Van de communicatie-activiteiten uit de proeftuin hebben met name de studiegroepbijeenkomsten, de masterclasses en de experimenten bruikbare kennis voor de veehouders opgeleverd. Volgens de geïnterviewde begeleiders werkten de masterclasses goed door een combinatie van gemotiveerde boeren en het uitnodigen van een inhoudelijke deskundige waar men mee kon sparren. Hierdoor kon men nieuwe kennis opdoen en tevens kennis delen, en tevens kon er specifieker op de bedrijfssituatie worden ingegaan. De studiegroepen waren inhoudelijk van lager niveau, waar de belangrijkste punten zijn besproken. De opzet van pilot-boer met volgerboeren heeft volgens de begeleiders goed gewerkt. De uitgevoerde experimenten waren niet wetenschappelijk opgezet, maar maakten zaken zichtbaar voor veehouders waardoor men daarover ging nadenken. De resultaten van de experimenten werden gecommuniceerd via nieuwsberichten en de website.

Een specifieke communicatie activiteit was het werken met een 'weer-app' en een WhatsApp groep. De 'weer-app' is bedoeld de melkveehouder te adviseren bij gunstig weer mest uit te rijden, waarbij ingespeeld wordt op de weersvoorspelling. Dit komt bij een aantal melkveehouders nogal belerend 
over, bovendien loop je het risico dat het gras alweer te lang is voordat het weer geschikt is.

Veehouders willen het dus zelf bepalen. De WhatsApp is gebruikt door de pilotboeren. Goede tips over de dagelijkse bedrijfsvoering werden uitgewisseld. De uitdaging is deze wel levendig te houden zonder belerend te zijn en er werd hierbij meer inbreng van adviseurs verwacht.

\section{Aansluiten bij kennisniveau melkveehouders en prikkel met de juiste toon (Educatie)}

De aanpak in de Proeftuin Veenweiden door kennis te ontwikkelen en uit te wisselen door en met pilotboeren en volgerboeren, het doen van experimenten op proef- en praktijkbedrijven, bijeenkomsten organiseren waarin onderzoekers, adviseurs en melkveehouders elkaar ontmoeten en goed gebruik maken van nieuwsbrieven en moderne media hebben goed gewerkt. Een voorwaarde is wel dat elke communicatieactiviteit gericht is op het kennisniveau van de doelgroep. Pilotboeren hebben bijvoorbeeld meer interesse om met tools en cijfers te werken dan volgerboeren. Een mix van activiteiten zorgt voor levendigheid en biedt kansen om aan te sluiten bij de diversiteit in kennisniveau en leerstijl van de deelnemers. Dit vergt veel discipline van betrokken partijen. En het vergt ook de juiste houding qua toonzetting. Teveel druk zetten op het realiseren van bepaalde doelen kan belemmerend werken. Aanbevelingen doen om de bedrijfsvoering aan te passen die voor betreffend melkveehouder of adviseur niet als realistisch worden gezien wekt irritatie op en kan daardoor averechts werken. Toch is enige druk wel nodig (waar wrijving is ontstaat glans) om vooruitgang te boeken, ondanks praktische beperkingen. Denk hierbij met name aan mest aanwenden bij gunstig weer en minder eiwit voeren. Dit zou je kunnen noemen: confronterend coachen of zoals een adviseur het verwoordde: "Ik ga veehouders niet ontzorgen, maar ik maak ze assertiever". Ontzorgen door de administratie over te nemen helpt niet voor de bewustwording. Assertiever maken geldt zowel naar de adviseurs toe als naar zichzelf door kritisch naar de eigen bedrijfsvoering te laten kijken (met oog, neus, oor en analyses van voer, bodem, gras).

\section{Sociale druk verschilt tussen pilot en volgerboeren (Sociale druk)}

Adviseurs zorgen voor sociale druk bij volgerboeren. Zij willen graag advies op maat. Pilotboeren reageren op sociale druk vanuit de maatschappij. Druk uitoefenen op adviseurs, bijvoorbeeld om minder eiwit te voeren, werkt goed via pilotboeren. Pilotboeren willen gecoacht worden en laten zich graag inspireren door een breed scala van adviseurs, onderzoekers of mensen buiten de landbouw. Zij zijn zich erg bewust van maatschappelijk normen en waarden.

\section{Stimuleer investeren in capaciteit (Economie)}

Om voldoende flexibel in te kunnen spelen op weersomstandigheden is voldoende mestopslag bij de melkveehouders nodig. Ook is voldoende capaciteit qua machines en menskracht gewenst bij loonwerkers om mest verdund uit te rijden onder de meest gunstige omstandigheden. Bij voldoende capaciteit kunnen meerdere melkveehouders tegelijkertijd bediend worden.

Belonen is een sterke stimulans. In deze proeftuin is dat gebeurd door veel begeleiding. Om impact te krijgen bij een grotere groep (peloton) helpt belonen via bijvoorbeeld melkpremie voor gewenst gedrag, ruimte voor bedrijfsvergroting, vergunning geven voor experimenteren of subsidies op gewenste investeringen (bijvoorbeeld onderwaterdrainage, meetapparatuur ed). Ook zouden melkveehouders die grenzen verkennen de risico's willen afdekken. Dat kan bijvoorbeeld ook door veel inzicht te geven in de bedrijfsvoering met analyses rond bijvoorbeeld grasproductie, graskwaliteit, diergezondheid en productie.

\section{Maak zowel simpele als meer diepgaandere tools (Tools)}

Het doorrekenen van de bedrijfsplannen per bedrijf en daarbij tevens onderscheid maken tussen binnen (stal) en buiten (veld) heeft goed gewerkt. Het geeft inzicht in wat mogelijk is, wat versterkt wordt door de resultaten te benchmarken met anderen.

De Kringloopwijzer (KLW) is een belangrijk instrument die inzicht geeft in de bedrijfsvoering. Het zijn resultaten achteraf met gemiddelden op dier-, bodem- en bedrijfsniveau. Voor een aantal melkveehouders geeft de KLW erg veel informatie, waardoor ze door de bomen het bos niet meer zien. Voor hen is een korte versie wenselijk ('KLW-light'), met basis kengetallen die voor iedereen gelijk is. Anderen willen graag meer diepgang. Dat kan op verschillende manieren, door:

- Naast analyseren achteraf ook te plannen vooraf (simuleren: alternatieven doorrekenen).

- Naast jaarcijfers ook tussenresultaten of resultaten dagelijkse bedrijfsvoering te tonen.

- Naast gemiddelde van alle ha's ook meer perceel specifieke kengetallen te tonen. 
Benut variatie (Educatie en tools)

Benut variatie geldt in allerlei opzichten. Ten eerste wordt ervoor gewaarschuwd geen

eenheidsworsten in de sector te creëren. Oplossingsrichtingen moeten passen bij de ondernemer en

de onderneming. Dit vergroot de kans op leren van elkaar. Experimenten op praktijkbedrijven en KTC Zegveld helpen de scope aan oplossingen te verbreden. Sommige melkveehouders geven echter aan dat KTC Zegveld te weinig aansluit bij de praktijk. Dit vergt een goede balans tussen innovatief (vooruitstrevend) en de dagelijkse praktijk.

Ook de variatie die er op een bedrijf is tussen percelen kan benut worden door maai- en bemestingsregimes te variëren tussen percelen. Ook geeft een adviseur aan bezig te zijn met het ontwikkelen van kansenkaarten, waarbij de natuurlijke variatie tussen percelen benut wordt qua kansen voor water- en natuuropgaven.

\section{Lessen voor opschalen naar achterblijvers}

\section{Suggesties voor impact creëren}

In deze Proeftuin hebben 10 pilotboeren en 87 volgerboeren meegedaan. De pilotboeren zijn intensief begeleid, de volgerboeren zouden meer begeleiding willen. De deelnemers willen graag beloond worden. Zij denken hierbij aan het verkrijgen van ontwikkelruimte (bijvoorbeeld meer vee of experimenteerruimte) als het lukt onder het $\mathrm{N}$-plafond te blijven of het doel qua verminderen ammoniak emissie bereiken. In dit project is echter de begeleiding ook een beloning. De begeleiding bij al die verschillende onderzoeks- en communicatieactiviteiten is intensief geweest en heeft de bewustwording vergroot, heeft tot veel inspiratie maar ook af en toe tot irritatie geleid en heeft daadwerkelijk gezorgd dat ruim $20 \%$ minder ammoniakemissie is bereikt. Deze groep zou graag verder willen met een meer integrale aanpak. De vraag is echter ook, hoe zou je een grotere groep melkveehouders kunnen motiveren de emissie van ammoniak te verminderen die minder begeleiding krijgen? Uit dit gedragsonderzoek leren we dat:

- Goed uitleggen van de noodzaak om emissies te beperken belangrijk is (waarom).

- Voor melkveehouders met weinig intrinsieke motivatie is wetgeving nodig die stuurt op bedrijfsniveau en indien mogelijk zoveel mogelijk op doelen en niet op middelen. Dit vergt vertrouwen en samenwerking tussen beleid en praktijk (industrie). Begeleidende voorlichting is nodig om aan te geven wat kan (wat). Dit kan ondersteund worden met bewustwordingsinstrumenten (hoe) als de Kringloopwijzer of door goede praktijk te belonen, bijvoorbeeld met een melkpremie zoals bij weidemelk of Planet Proof melk.

- Groepsbijeenkomsten waarbij praktijk en onderzoek elkaar ontmoeten erg leerzaam is, bovendien is dit goedkoper dan individuele begeleiding (hoe).

- $\quad$ Effecten laten zien van oplossingsrichtingen op emissies die zowel melkveehouders als adviseurs stimuleren (wat). Als het samengaat met economisch voordeel wordt de maatregel snel ingevoerd.

- Oplossingen niet strijdig zijn met andere doelen, of dat duidelijk gemaakt wordt wanneer sprake is van afwenteling, en moeten aansluiten bij de beleving (strategische en dagelijkse bedrijfsvoering) van de melkveehouder (wat).

- Mix van activiteiten qua kennisontwikkeling en -uitwisseling nodig is omdat elke melkveehouder anders leert.

- Gebruik van tools en apps waardevol zijn, maar niet overschat moeten worden.

\section{Aanvullende suggesties op maatregelen}

De adviseurs gaven de volgende suggesties van maatregelen die nog beperkt aandacht krijgen, maar wel perspectiefvol zijn of lijken:

- Mest scheiden in dikke (feces) en dunne (urine) fractie; dun aanwenden tot uiterlijk 1 juli en dik gehele seizoen.

- Vloeibare kunstmest wordt eerder opgenomen door de plant en biedt mogelijkheden de kunstmest beter te verdelen.

- $\quad$ Stromest is aantrekkelijk voor akkerbouwers.

- $\quad \mathrm{N}$-levering verlagen om hoge eiwitgehalten in gras te voorkomen kan door verhogen grondwaterpeil of toevoegen van klei aan de veengrond.

- Mak meerdere voorjaars (mei) kuilen en meng deze met andere snedes. 
- Maken van grasbrok kan aantrekkelijk zijn omdat grasoverschot dan beter te verhandelen is en het verhoogt DVE. Het vergt echter een duurzame energiebron en grastransport moet qua logistiek passen op de wegen in die regio, anders is het economisch niet perspectiefvol.

- Benut de voordelen van een voermengwagen. Het speelt in op de trend dat voeren steeds meer uitbesteed wordt en het dwingt de melkveehouder kritisch na te denken over de keuze van grondstoffen.

\section{Lessen voor de kennisinfrastructuur}

Onderstaande aanbevelingen zijn gebaseerd op discussie met het projectteam.

\section{Meer samenwerking tussen de Zuivelketen en overheid}

De gedragsveranderingen in dit project zijn tot stand gebracht onder regie van het projectteam Proeftuin Veenweiden. Een project zorgt echter niet voor continuïteit en daarom is het belangrijk dat anderen de regie nemen. Voortbordurend op integrale doelen en de aanzet die de Duurzame Zuivelketen al heeft gemaakt op aandacht voor meerdere doelen, ligt het voor hand dat het Ministerie en de Zuivelindustrie hun regierol goed op elkaar afstemmen. Daarbij is het belangrijk goede kengetallen te definiëren op bedrijfsniveau. Ook is het belangrijk tijdig commitment te krijgen van de Diervoedersector. De regisseur geeft richting aan, 'onafhankelijke' adviseurs ondersteunen met name bij de planvorming en adviseurs van bedrijfsleven ondersteunen bij de uitvoering. De rol van kennisinstellingen is bestaande kennis te ontsluiten en nieuwe grenzen te verkennen (aangeven wat kan).

\section{Interactie tussen spelers in de kennisinfrastructuur}

Hoewel de interviews en de enquête maar uitgevoerd zijn bij een kleine groep van ca. 100 deelnemers in een specifieke regio op een specifiek onderwerp, namelijk beperken ammoniakemissie in het veenweidegebied, zijn er wel lessen te leren over de interactie tussen melkveehouders, adviseurs (mengvoerindustrie, dierenarts, accountant, zuivel, DLV, PPP-Agroadvies) en onderzoekers. Groepsbijeenkomsten lijken efficiënt en effectief te zijn, met name masterclasses scoren goed. Dit werkt goed omdat theorie en praktijk bij elkaar komen. Deze interactie geeft inzicht in grenzen in haalbaarheid bijvoorbeeld op het gebied van bemesting- en voedingsmaatregelen. Om die grenzen te kunnen aangeven is inzicht nodig in bodem - plant - dier relaties, niet alleen qua mineralenstromen maar ook qua diergezondheid en economie. Bovendien is inzicht nodig in effecten van maatregelen op meerdere doelen en waar werken maatregelen elkaar tegen. Deze informatie is ook van belang voor beleid. Daarom is het ook belangrijk resultaten uit deze en andere proeftuinen te gebruiken voor evaluatie van beleid.

\section{Impact creëren met nieuwe leeromgevingen}

Door wetgeving kun je maatregelen afdwingen, met beloningsinstrumenten kun je maatregelen stimuleren. Bovendien is dit vrijwillig. Door kennisuitwisseling tussen verschillende partijen stimuleer je bewustwording qua urgentie (waarom) en qua mogelijkheden (wat kan). Dit gebeurt niet vanzelf. De kunst is een kennisinfrastructuur te maken waarin er een goede rolverdeling tussen partijen is, men elkaar versterkt en eenieder zich kan profileren. Dit betekent bijvoorbeeld dat onderzoekers helpen de juiste tools of rekenregels te ontwikkelen die adviseurs kunnen gebruiken. Ook data van praktijkbedrijven zijn zinvol voor benchmarking en zoeken van verbanden. Hierin kunnen onderzoekers en adviseurs elkaar versterken. Nieuwe technieken qua dataverzameling, dataopslag, weergave kengetallen en communicatie helpen om efficiënt en effectief te communiceren. Dit vergt nadere uitwerking en tevens een houding om kennis te willen delen. Het gebruik van tools en apps ed. moet echter ook niet overschat worden. Het zijn hulpmiddelen die ingezet kunnen worden in groepsbijeenkomsten waarin men elkaar stimuleert, soms zelfs door te irriteren. Het gaat erom de juiste toon te zetten zodat men leert van elkaar.

Veel impact kan gecreëerd worden door het opzetten van een gezamenlijke leeromgeving tussen de verschillende partijen waarin men elkaar versterkt. Deze leeromgeving is een combinatie van digitaal, groepsbijeenkomsten en individuele begeleiding. Het idee is deze met moderne technieken te versterken, zoals bijvoorbeeld een excursie op afstand door gebruik van camerabeelden tijdens rondleiding of cijfers bediscussiëren in een skype bijeenkomst, etc. Deze nieuwe leeromgeving met 
een sterke relatie tussen praktijk, adviseurs, onderzoek en ook beleid kan zorgen voor gedragsverandering bij alle partijen. De Proeftuin Veenweiden is een goed voorbeeld, maar zou sterker worden als meer data / kengetallen van de bedrijven worden gebruikt voor dagelijkse advisering, tactische beslissingen, onderzoekdoeleinden (bijvoorbeeld benchmarken en simuleren) en beleidsadvisering of beloningsinstrumenten. 


\section{$1 \quad$ Inleiding}

\section{$1.1 \quad$ Achtergrond}

In het project 'Proeftuin Veenweiden' voor de provincies Zuid-Holland en Utrecht werken melkveehouders en periferie aan het reduceren van ammoniakemissies vooral door het verbeteren van het mest- en voermanagement. Voor de Provincie Utrecht wordt daarnaast de innovatie 'bemesten afhankelijk van bodemtemperatuur van grasland' getoetst. Honderd veehouders, waarvan tien pilotboeren maken jaarlijks een strategisch plan en nemen meerdere operationele besluiten per jaar, zoals op welke wijze en op momenten percelen bemest worden, wanneer maaien, hoeveel beweiden en het aanpassen van rantsoen.

Binnen de 'Proeftuin Veenweiden' is behoefte om de melkveehouders en adviseurs (individueel en in groepen) meer tijd te laten besteden aan het doorgronden van het 'hoe en waarom?' van implementeren van emissie reducerende maatregelen. Wat waren de factoren die bepaalden dat de melkveehouder een ander besluit nam, hoe gemakkelijk of lastig was dit om uit te voeren (en vol te houden) en wat is het succes van de maatregel?

$\mathrm{Er}$ is behoefte aan praktische methoden om deze lessen te vinden en te duiden en daarmee bewust 'kwartjes te laten vallen' bij boeren en adviseurs. Uit eerdere projecten (bijv. Praktijkcijfers2) blijkt dat deze 'kwartjesvalmomenten / leerervaringen' de veehouders helpen om de verduurzaming van hun bedrijf beter vol te houden en te versnellen.

\subsection{Doel}

Het doel van het onderzoek was te ontdekken welke factoren een rol spelen om wel of niet bepaalde maatregelen te nemen om de ammoniakemissie te beperken door melkveehouders in samenwerking met adviseurs en loonwerkers. Het gaat erom de gedragsverandering bij deze doelgroepen te analyseren en te duiden door te onderzoeken wat motiveert en belemmert om maatregelen wel of niet in de praktijk toe te passen. 


\section{Materiaal en Methode}

Er zijn twee werkwijzen toegepast om gedragsverandering te analyseren, namelijk interviews bij een steekproef van pilotboeren en volgers, een enquête onder alle deelnemende melkveehouders uit de Proeftuin Veenweiden en interviews bij enkele begeleiders, adviseurs en een loonwerker. De interviews betroffen een kwalitatieve analyse en de enquête betrof een kwantitatieve analyse, die inzicht geeft in hoe belangrijk een bepaalde maatregel was en welke prikkels daarbij een rol hebben gespeeld.

\subsection{Interviews bij melkveehouders}

In het voorjaar 2018 zijn vijf pilot melkveehouders en vijf volger melkveehouders geïnterviewd met behulp van een vragenlijst die de interviewers als leidraad voor het gesprek aanhielden. Zie bijlage 1 voor de vragenlijst. Het doel van deze interviews was om inzicht te krijgen in de factoren waarom bepaalde maatregelen wel of niet worden toegepast. Door wie of wat wordt de veehouder sterk beïnvloed? Hoe laat hij/zij zich informeren en hoe leert een melkveehouder, zoals bijvoorbeeld via gesprekken met collega's of studiegroepen, via de media, van adviseurs, etc. En welke belemmeringen ervaart men om bepaalde maatregelen toe te passen.

De interviews werden vastgelegd in een gespreksverslag. De resultaten van de interviews zijn vervolgens gebundeld op de volgende punten:
1. Motivatie voor deelname
2. Positieve ervaringen uit de Proeftuin
3. Negatieve ervaringen uit de Proeftuin
4. Kwartjesmoment
5. Belemmeringen
6. Motivatie
7. Beïnvloeders
8. Voldoening
9. Zorgen
10. Duurzaamheid
11. Tips voor het project

\subsection{Enquête onder deelnemende melkveehouders}

In het najaar 2018 is via internet een enquête gehouden onder alle deelnemende melkveehouders uit de Proeftuin Veenweiden. De vragen uit de enquête staan weergegeven in bijlage 2. De vragen in de enquête zijn mede gebaseerd op de resultaten van de interviews met de veehouders. Het doel van deze enquête was om inzicht te krijgen in de volgende onderwerpen:

- Het belang van het reduceren van ammoniak i.r.t. de doelen van de Duurzame Zuivelketen.

- Het toepassen van ammoniak reducerende maatregelen en wat de belangrijkste is, waarom dit wel/niet wordt gedaan.

- Welke invloedsfactoren van belang zijn geweest om ammoniak reducerende maatregelen toe te passen.

- Welke belemmeringen worden ervaren om (nog meer) veranderingen in het bedrijfsmanagement door te voeren om de ammoniakemissie te verminderen.

- Wat de drie belangrijkste kennisbronnen zijn.

- Welke communicatie-activiteiten bruikbare nieuwe kennis heeft opgeleverd.

- Hoe belangrijk men een aantal onderwerpen in de bedrijfsvoering vindt.

- Wat men vindt van het verloop van de Proeftuin Veenweiden. 
Bij de analyse zijn de pilot-bedrijven niet apart geanalyseerd van de volg-bedrijven omdat de pilotbedrijven een klein deel (12\%) van de reacties uitmaakte.

\subsection{Interviews bij begeleiders, adviseurs en loonwerker}

In het najaar 2018 zijn twee groepsbegeleiders uit de Proeftuin Veenweiden, twee onafhankelijke adviseurs, een voerleverancier en een loonwerker geïnterviewd met behulp van een vragenlijst die de interviewers als leidraad voor het gesprek aan hielden, zie bijlage 3 . Het doel van deze interviews was om inzicht te krijgen wat zij als de belangrijkste maatregelen zien om de ammoniak te verminderen in het veenweidegebied, welke prikkels goed en slecht werken om gedragsverandering te bewerkstelligen bij zowel de pilot- en volgers-melkveehouders, en welke communicatie activiteiten veel impact hebben gehad.

\subsection{Methode}

Gedragsveranderingen van grotere groepen mensen vraagt meer dan nieuwe kennis. De aanbevelingen die dit project oplevert, zijn gebaseerd op de RESET methode. Verschillende ondernemers hebben verschillende motieven voor gedragsverandering. Op vijf gebieden: regels, educatie, sociale druk, economische prikkels en tools zijn interventies nodig om een grotere groep veehouders deze kwartjesval momenten te laten ervaren (zie figuur 1).

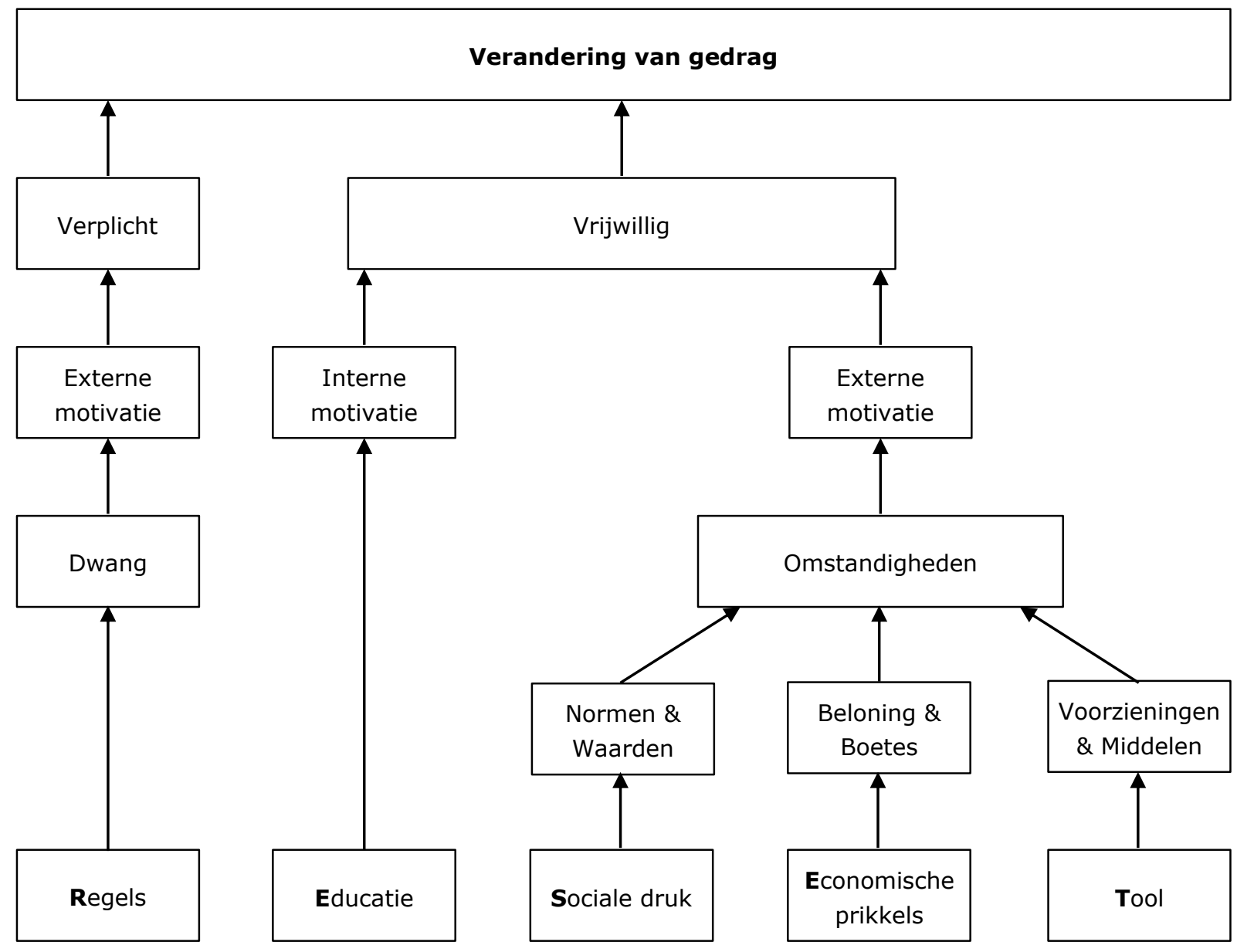

Figuur 1 Gedragsverandering volgens de RESET-methode (Jansen et al., 2012). 
De RESET methode maakt onderscheid in vijf gebieden van gedragsverandering, namelijk:

- Regels; regels en wetten leiden tot verplichten en zorgen voor externe motivatie.

- Educatie; door te begrijpen hoe iets zit zorgt voor interne motivatie.

- Sociale druk; door elkaar normen en waarden op te leggen wil je niet buiten de boot vallen.

- Economische prikkels; beïnvloeden kosten en opbrengsten door een bonus of boete.

- Tools; zij maken het makkelijker bepaalde maatregelen te nemen.

In het rapport 'Beleidsinstrumenten voor energieneutrale en klimaatvriendelijk agrosectoren' (Lauwere et al., 2017) is de Reset methode vergeleken met twee andere methoden van gedragsbeïnvloeding, zie Tabel 1.

Tabel 1 Drie methoden die als kader voor gedragsbeïnvloeding kunnen dienen.

\begin{tabular}{lll}
$\begin{array}{ll}\text { RESET } \\
\text { (Jansen et al, 2012) }\end{array}$ & Gedragsveranderingswiel & \multicolumn{1}{c}{ Wortel, Stok en preek } \\
Regels & Willen & (Memelmans-Videc et all, 2003) \\
\hline Educatie & Weten & Preek \\
\hline Sociale druk & Willen & Preek \\
\hline Economische incentives & Willen en kunnen & Wortel \\
\hline Tools & Weten en kunnen & Wortel \\
\hline
\end{tabular}

Toelichting tabel:

Het gedragsveranderingswiel beschrijft:

Weten: $\quad$ weet een persoon hoe hij of zij een bepaalde verandering moet doorvoeren

Willen: wil hij of zij een bepaalde verandering doorvoeren (motivatie)

Kunnen: $\quad$ kan en heeft hij of zij (of het bedrijf) de mogelijkheid voor verandering

De andere methode beschrijft positieve en negatieve prikkels, namelijk:

Wortel: $\quad$ als je dit doet dan krijg je....(positieve prikkel door beloning)

Preek: het is goed als je dit doet, want...(positieve prikkel door voorlichting)

Stok: je moet dit doen, of anders...(negatieve prikkel of dwang)

Om de melkveehouders in beweging te krijgen zal een combinatie van prikkels nodig zijn. Voor dit project is een communicatiestrategie beschreven (Jolien Koole, februari 2016). Met dit gedragsonderzoek kunnen acties (verschillende typen prikkels) uit het communicatieplan geëvalueerd worden. 


\subsection{Algemeen}

Van 97 deelnemende melkveehouders hebben 57 melkveehouders de enquête ingevuld (59\%). Van 57 enquêtes waren 7 afkomstig van pilotboeren en 50 afkomstig van volgerboeren. Van de 57 melkveehouders die mee deden was de jongste 21 jaar, de oudste 69 jaar en de gemiddelde leeftijd was 47 jaar. Van de respondenten had 7\% een LBO, 72\% een MBO, 21\% een HBO en $0 \%$ een WO als laatst voltooide opleiding gehad.

\subsection{Typering van de melkveehouders}

Motivatie van de geïnterviewde melkveehouders voor deelname aan de Proeftuin

De motivatie om zich aan te melden bestond voor de pilotboeren uit de volgende redenen:

- Interesse in het onderzoeken van dingen.

- Toe aan/op zoek naar een nieuwe uitdaging, waarbij één veehouder aangaf dat dit zowel bedrijfsvoering als maatschappelijke doelen betrof.

- $\quad$ Zin in iets nieuws, in voor nieuwe dingen.

- Voorkomen van bedrijfsblindheid, spiegelen met andere veehouders, leuk vinden van buitenstaanders te horen hoe ze tegen je bedrijf aankijken en wat je kan verbeteren op je bedrijf.

- Interesse in mineralen.

- Was al bezig met verlagen van het ruw eiwitgehalte in het rantsoen en wilde daarmee meegaan.

- Als sector aantonen dat we de reductie van ammoniak aan kunnen tonen om er ontwikkelruimte voor terug te krijgen.

De meest gehoorde reden voor aanmelding bij de pilotboeren was dat men nieuwe uitdagingen zoekt c.q. in is voor nieuwe dingen.

De motivatie om zich aan te melden bestond voor de volgerboeren uit de volgende redenen:

- $\quad$ Leren van het project.

- Ammoniakemissie is een belangrijk onderwerp, kan meer impact hebben dan fosfaat, voorkomen van teruggang in aantal koeien.

- Interesse in mineralen en hoe met de mineralen op het bedrijf wordt omgegaan.

- Interesse in verlaging van het ruw eiwitgehalte want ze waren al bezig met het verlagen van ruw eiwit gehalte.

De meest gehoorde reden voor aanmelding bij de volgerboeren was dat men wilde leren van het project en de impact die ammoniakemissie kan gaan hebben op de bedrijfsvoering.

\section{Typische kenmerken van pilot- en volgerboeren volgens de geïnterviewde adviseurs}

Volgens de geïnterviewde adviseurs zijn typische kenmerken van pilot-boeren dat ze een grote intrinsieke motivatie hebben en komen niet alleen halen maar ook brengen. Ze zijn nieuwsgierig, staan open voor nieuwe dingen, willen bijleren, willen weten hoe het zit en zijn tevens ook kritisch. Ze zijn goed geïnformeerd, willen gecoacht i.p.v. geadviseerd worden, zetten hun eigen route uit en weten welke stappen ze moet zetten met het besef dat ze zelf verantwoordelijk zijn voor hun resultaten. Verder experimenteren ze op hun eigen bedrijf en zijn ze bewust van dat ze een license-toproduce nodig hebben.

Volgens de adviseurs zit er bij volger-boeren een veel grotere variatie qua type boer. Er is een deel die verandert, en een deel die meer waarneemt en aanhoort. Ze kijken meer naar de voorlopers en luisteren meer naar de voeradviseur. Volger-boeren willen een advies voor hun bedrijf. Ze hebben niet 
het totaalplaatje van hun bedrijf in beeld wat pilot-boeren hebben, kijken minder vooruit en opereren meer in het huidige moment.

Mindset ondernemer

Gemiddelde score van de respondenten over hoe belangrijk ze deze uitspraken voor hun zelf vinden op een score van 1 tot 7 (van heel onbelangrijk tot heel belangrijk), gesorteerd van hoog naar laag:
1. Ik streef naar een hoge levensduur per koe
5.86
2. Ik streef naar een hoge mineralenefficiëntie van het bedrijf
5.74
3. Ik streef naar een hoge mineralenefficiëntie van de bodem
5.61
4. Ik streef naar veel melk uit vers gras
5.42
5. Ik streef naar een hoge mineralenefficiëntie van het vee
5.37
6. Ik zoek graag de grenzen op qua bemesting
4.74
7. Ik streef naar een hoge melkproductie per koe
4.68
8. Ik zoek graag de grenzen op qua voeding
4.61

\section{Duurzaamheid}

De volgende zaken werden door de geïnterviewde veehouders zelf aangegeven over wat zij vinden wat een duurzame melkveehouderij betekent:

- $\quad$ Continuïteit \& balans

- Rond kunnen zetten van de bedrijfsvoering: balans tussen vee en land, bemesting, voer en gezondheid i.c.m. goede melkproductie.

- Werk/privé/financieel zijn in balans.

- Efficiënt en lang houdbaar: continuïteit, koeien met een lange levensduur, machines met een lange levensduur, ook milieu (verstoken van olie en gas is niet houdbaar), bodem.

- Toekomstgericht en zichzelf staande kan houden door voldoende geld te genereren en rekening te houden met natuur: lage $\mathrm{CO} 2$ uitstoot, hoge levensduur, lage sterfte en uitval, laag antibioticagebruik.

- Goede benutting van elke aankoop (voer en machines).

- Kringloop: waarbij één veehouder aangaf dat dit niet zozeer grondgebondenheid hoeft te zijn.

- Grond \& Bodem

$\circ \quad$ Meer grondgebonden en zelfvoorzienend te worden.

- Grondgebonden bedrijf die past in de omgeving.

- Een gezonde bodem doorgeven aan de volgende generatie.

- Letten op geschikte bemesting.

- Verwachting dat kunstmest verdwijnt.

- Voer

- Voer zoveel mogelijk van eigen land, maar krachtvoer is lastig op veengrond.

- Verantwoord produceren (VLOG) o.a. geen genetisch gemodificeerde soja.

- Vee

- Gezonde veestapel met beweiding.

- Verhogen van de leeftijd van de veestapel.

o Duurzame stal.

- Milieu

- Werken aan ammoniak is belangrijk want het levert geld op.

- Minder milieubelasting: de veehouderij drijft nog te veel op import \& input, meer zelfvoorzienend.

- Natuur

- Rekening houden met weidevogels.

- Beheren van natuurgrond.

- Boeren met oog voor milieu \& natuur, meer biodiversiteit, geen monocultuur van gras, gewasdiversificatie voor akkerbouwers.

- $\quad$ Energie

- Energie: zoveel mogelijk van eigen bedrijf halen, maar moet wel haalbaar zijn.

- Zuinig omgaan met energie. 


\section{- Financieel}

- Voldoende inkomen om ook de maatschappelijke doelen te kunnen betalen.

- De omvang moet groot genoeg zijn en er moet geld verdiend worden.

- Minder afhankelijk van derden: banken, afzetindustrie/supermarkten, meer invloed op de afzet hebben en daarmee samenhangend een eerlijkere prijs en productwaardering krijgen.

- Maatschappij

- De maatschappij het verhaal van de boer vertellen. Zorg dat de acceptatie onder burgers wordt vergroot. Denk aan de wensen van de consument.

- Geaccepteerd worden door de omgeving, het liefst ook gewaardeerd.

\section{Doelen duurzame zuivelketen}

De drie meest belangrijke doelen van de Duurzame Zuivelketen (DZK, 2017) voor hun bedrijf vonden de respondenten:

1. Verlengen levensduur melkkoeien (gem. score 5,82 van de 7).

2. Behoud van weidegang (gem. score 5,75 van de 7 ).

3. Verminderen van ammoniakuitstoot (gem. score 5,60 van de 7).

De drie minst belangrijke doelen van de Duurzame Zuivelketen voor hun bedrijf vonden de respondenten:

1. Verlagen fosfaatproductie dierlijke mest (gem. score 4,12 van de 7).

2. Meer integraal duurzame stallen (gem. score 4,25 van de 7).

3. Gebruik van duurzame soja en palmpitschilfers (gem. score 4,53 van de 7 ).

\section{Voldoening van de geïnterviewde melkveehouders}

De geïnterviewde veehouders gaven uit de volgende zaken de meeste voldoening te halen:

- Bedrijfsvoering

- Van alle verschillende taken die op de boerderij te doen zijn.

- Vooruitgang zien in de leeftijd van de koeien.

- Als de koeien het goed doen en financieel ook goed loopt.

- Als het totaalplaatje van het bedrijf klopt, als het lekker loopt en bedrijfstechnisch goed draait.

- In het voorjaar koeien naar buiten en gras maaien, melken, mooie melkproductie onder de koe en dat het lekker op het bedrijf loopt.

- Als het goed gaat met de koeien. Als alles lekker loopt en al het werk gedaan is, dan buiten lekker naar de koeien kijken en zien herkauwen.

- Als het lekker loopt op het bedrijf en je je eigen dingen kunnen doen.

- Innoveren

- Nieuwe dingen uitproberen.

- Meedenken om kennis te vergaren en ontwikkelen om ammoniak probleem op te lossen.

- Zelfstandigheid

○ Je eigen dingen kunnen doen, niet te veel gedoe.

- $\quad$ Biodiversiteit

- Vooruitgang zien in aantal weidevogels op zijn bedrijf (meer natuur op het bedrijf).

- Contacten

- Contact met burgers op zijn bedrijf.

De meeste voldoening geeft de veehouders als het lekker/goed op het bedrijf draait.

\section{Zorgen van de geïnterviewde melkveehouders}

De geïnterviewde veehouders gaven aan dat de volgende zaken hun de meeste zorgen geeft:

- $\quad$ Regelgeving

- Onberekenbare regelgeving zoals fosfaatregelgeving.

- Gezeur rondom (fosfaat)regelgeving.

- Politieke beslissingen die op emoties worden gemaakt.

- Vraag of alle wetgeving wel allemaal tot hetzelfde doel leiden.

- Mogelijke sancties die men zou kunnen opleggen t.a.v. ammoniakemissie. 
- Dat de lust om te boeren wordt weggehaald, dat het allemaal teveel eenheidsworsten in de sectoren worden en dat teveel verkeerde prikkels worden afgegeven.

- Bang dat reductie in ammoniakemissie ten koste gaat van andere zaken op het bedrijf: vee of grond te ver uitkleden op de lange termijn, teruggang in gezondheid of graslandproductie die te ver terugloopt.

- Hoe kan je andere boeren bewust maken dat ammoniakemissie een probleem wordt? $\mathrm{Nu}$ kunnen we het nog zelf oplossen. Hoe krijg je de kennis op de juiste plek.

- Media

- Bepaald berichtgeving die emoties opwekken: beeld dat wat van de sector wordt geschept. Hoe krijg je een genuanceerder beeld bij bestuurders? Landbouw zou meer werk moeten maken van een goede lobby.

- Bedrijfsvoering

- Als je alles volgens het boekje doet en het dan toch niet lekker loopt op het bedrijf.

- Onvoldoende financiën om investeringen te kunnen doen.

De meeste zorgen krijgen de veehouders van (onberekenbare) regelgeving en de gevolgen daarvan op de bedrijfsvoering.

\subsection{Maatregelen}

In bijlage 4 staan de resultaten van de vragen over toepassing van ammoniak reducerende maatregelen uit de internet enquête weergegeven. In deze paragraaf worden de resultaten beknopt beschreven.

\section{Minder jongvee}

In 2017 en 2018 gaf 73,7\% van de geënquêteerde melkveehouders aan minder jongvee (aantal stuks per 10 melkkoeien) te zijn gaan aanhouden t.o.v. 2016. De drie belangrijkste redenen om minder jongvee te gaan aanhouden waren:

- Het verminderen van de fosfaatproductie op het bedrijf $(35,7 \%)$.

- Het nastreven van een lange levensduur van het vee $(35,7 \%)$.

- Vanwege fosfaatrechten (16,7\%).

Van deze melkveehouders verwacht ruim de helft $(54,8 \%)$ de komende jaren hetzelfde aantal stuks jongvee per 10 melkkoeien aan te blijven houden. Bijna een kwart $(23,8 \%)$ weet het nog niet en bijna een kwart $(23,4 \%)$ zal niet hetzelfde stuks jongvee blijven houden. De belangrijkste redenen voor verandering is dat men aantal stuks verder wil verlagen omdat het nog scherper kan of omdat men het wil verhogen omdat men nu te laag zit met het aantal stuks jongvee.

De drie belangrijkste redenen om niet minder jongvee te gaan aanhouden vanaf 2016 waren:

- Men al weinig jongvee aanhield (53,3\%).

- Men ruwvoer over had op het bedrijf $(26,7 \%)$.

- Men geen jongvee aanhield op het bedrijf $(13,3 \%)$.

\section{Meer beweiden}

In 2017 en 2018 gaf 22,8\% van de geënquêteerde melkveehouders aan meer te zijn gaan beweiden t.o.v. 2016. De drie belangrijkste redenen om meer te gaan beweiden waren:

- Men een lage kostprijs wil realiseren (38,5\%).

- Men veel melk uit vers gras wil produceren $(30,8 \%)$.

- $\quad$ Anders $(30,8 \%)$.

Van deze melkveehouders verwacht ruim driekwart $(76,9 \%)$ dat ze de komende jaren meer blijven beweiden, terwijl 23,1\% het nog niet weet.

De drie belangrijkste redenen om niet meer zijn gaan beweiden sinds 2016 waren:

- Men al maximaal probeert te beweiden $(63,6 \%)$.

- De huiskavel te klein is $(11,4 \%)$.

- Men de koeien jaarrond op stal wil houden $(6,8 \%)$.

- Men melkt met een robot $(6,8 \%)$. 
Mest uitrijden bij gunstig weer

In 2017 en 2018 gaf 59,7\% van de geënquêteerde melkveehouders aan mest onder gunstigere weersomstandigheden gaan (laten) uitrijden t.o.v. 2016. De drie belangrijkste redenen om mest onder gunstigere omstandigheden te gaan (laten) uitrijden waren:

- Men flexibel is met eigen bemestingsapparatuur $(44,1 \%)$.

- Men wacht op goede weersomstandigheden $(32,4 \%)$.

- De loonwerker over voldoende capaciteit beschikt $(20,6 \%)$.

Van deze melkveehouders verwacht ruim driekwart $(76,5 \%)$ dat ze de komende jaren mest onder gunstige omstandigheden zullen blijven uitrijden, terwijl 17,7\% het niet weet en $5,9 \%$ verwacht van niet omdat het afhankelijk is van de loonwerker.

De drie belangrijkste redenen dat men mest niet onder gunstigere omstandigheden is gaan uitrijden sinds 2016 waren:

- Men dit al deed voor 2017 (34,8\%).

- De loonwerker niet altijd op het geschikte moment beschikbaar is $(30,4 \%)$.

- De weersomstandigheden te wisselvallig zijn $(26,1 \%)$.

\section{Mest verdunnen}

In 2017 en 2018 gaf 70,2\% van de geënquêteerde melkveehouders aan mest verdund uit te hebben gereden, waarbij dat in 2016 nog niet het geval was. De drie belangrijkste redenen om mest verdund uit te gaan rijden waren:

- Het een betere benutting van de mineralen geeft $(50,0 \%)$.

- Het minder stikstofverliezen geeft door minder ammoniakemissie $(45,0 \%)$.

- Anders $(5,0 \%)$.

Deze veehouders verwachten allemaal (100\%) dat ze de komende jaren verdund mest blijven uitrijden.

De drie belangrijkste redenen om niet mest verdund te gaan uitrijden sinds 2016 waren:

- Men al mest verdund uitrijdt $(82,4 \%)$.

- Uitrijden dan meer tijd en geld kost (5,9\%).

- Men daar de bemestingsapparatuur niet voor heeft (5,9\%).

- Men zelf met de tank uitrijd en een deel drassig land op afstand heeft (5,9\%).

\section{Minder eiwit in het rantsoen}

In 2017 en 2018 gaf 70,2\% van de geënquêteerde melkveehouders aan een rantsoen met minder ruw eiwit te zijn gaan voeren t.o.v. 2016. De drie belangrijkste redenen of methoden om minder ruw eiwit te gaan voeren waren:

- Men meer eiwitarmere voerproducten is gaan aankopen $(45,0 \%)$.

- Gras met een lager ruw eiwit is gaan oogsten $(35,0 \%)$.

- Meer mais in het rantsoen is gaan voeren $(12,5 \%)$.

Van deze melkveehouders verwacht bijna tweederde $(65,0 \%)$ dat ze de komende jaren een rantsoen met minder ruw eiwit blijven voeren, terwijl $27,5 \%$ het niet weet en $7,5 \%$ verwacht van niet omdat het eiwitgehalte al laag is of een aanvulling in DVE nodig is voor de efficiëntie van de eiwitomzetting.

De drie belangrijkste redenen dat men niet een rantsoen met minder ruw eiwit sinds 2016 is gaan voeren waren:

- Men een lagere melkproductie verwacht $(58,8 \%)$.

- Zit al laag met ruw eiwit, voer al op de norm $(29,4 \%)$.

- Mijn voeradviseur raadt dat af $(1,8 \%)$.

\section{Minder eiwitrijk gras}

In 2017 en 2018 gaf 45,6\% van de geënquêteerde melkveehouders aan gras met een lager ruw eiwit te gaan winnen t.o.v. 2016. De drie belangrijkste redenen of methoden om gras met minder ruw eiwit te gaan winnen waren:

- Men minder kunstmest is gaan strooien $(57,7 \%)$.

- Men later is gaan maaien $(15,4 \%)$.

- Men minder eiwit en meer structuur wil voeren $(11,5 \%)$. 
Van deze melkveehouders verwacht bijna tweederde $(61,5 \%)$ dat ze de komende jaren gras met minder ruw eiwit blijft winnen, terwijl 30,8\% het niet weet en $7,7 \%$ verwacht van niet omdat het ruw eiwitgehalte nu te laag is of omdat het ruw eiwit gehalte in de zomer moeilijk te sturen is.

De drie belangrijkste redenen dat men niet gras met een lager ruw sinds 2016 zijn gaan winnen waren:

- Men zoveel mogelijk ruw eiwit van eigen land wil halen $(41,9 \%)$.

- Door de hoge stikstofmineralisatie op mijn grond lukt dat niet $(29,0 \%)$.

- Men liever het rantsoen stuurt via aangekocht voer $(6,5 \%)$.

\section{Aanvullende suggesties op maatregelen van de adviseurs}

De adviseurs gaven de volgende suggesties aan qua aanscherpen van bemesting graslandmanagement - voeding die nog beperkt aandacht krijgen, maar wel perspectiefvol zijn of lijken:

- Mest scheiden in dikke (feces) en dunne (urine) fractie; dun aanwenden tot uiterlijk 1 juli en dik gehele seizoen.

- Vloeibare kunstmest wordt eerder opgenomen door de plant en biedt mogelijkheid de kunstmest beter te verdelen.

- $\quad$ Stromest is aantrekkelijk voor akkerbouwers.

- $\quad \mathrm{N}$-levering verlagen om hoge eiwitgehalten in gras te voorkomen kan door verhogen grondwaterpeil of toevoegen van klei aan de veengrond.

- Maak meerdere voorjaars (mei) kuilen en meng deze met andere snedes.

- Maken van grasbrok kan aantrekkelijk zijn omdat grasoverschot dan beter te verhandelen is en het verhoogt DVE. Het vergt echter een duurzame energiebron en grastransport moet qua logistiek passen op de wegen in die regio, anders is het niet perspectiefvol.

- Benut de voordelen van een voermengwagen. Het speelt in op de trend dat voeren steeds meer uitbesteed wordt en het dwingt de melkveehouder kritisch na te denken over de keuze van grondstoffen.

Belang van het verminderen van de ammoniakemissie volgens de geïnterviewde adviseurs De adviseurs vinden het verminderen van de ammoniakemissie belangrijk vanwege het Programma Aanpak Stikstof (PAS), de door sector beloofde reductie in ammoniakemissie en vanwege het stikstofplafond. Wel werden er ook kanttekeningen geplaatst bij de manier waarop. Zo gaf een adviseur dat integrale stikstofverliezen in de kringloop belangrijker zijn dan een puur eenzijdig beleid gericht op ammoniak. Een andere adviseur vond verlaging van het ureumgehalte nodig, gebruik van andere kunstmeststoffen voor het veenweidegebied en zorgen voor een betere eiwitbenutting door betere sturing op DVE en OEB in het rantsoen.

Volgens de adviseurs is het besef bij de pilotboeren er wel dat ammoniakemissie een belangrijk onderwerp is voor de sector. Bij volger-boeren ligt volgens de adviseurs de focus nog op fosfaat en is men wel in het hoofd bezig met vermindering van ammoniakemissie maar overheerst het gevoel nog dat maatregelen nemen vooral geld kost.

\section{Belang en redenen van de maatregelen volgens de geïnterviewde adviseurs}

- $\quad$ Minder jongvee

- Dit wordt door de adviseur gezien als een goede maatregel.

○ Vanwege de fosfaatregelgeving zijn de meeste veehouders minder jongvee gaan aanhouden.

- Meer weiden

- Dit wordt door de adviseur gezien als een positieve maatregel.

- De reden om meer te gaan beweiden doet men vooral om andere redenen, waarbij verlaging van de ammoniakemissie dan mooi is meegenomen.

- Men doet de koeien vooral eerder naar buiten, langer doorweiden is vooral afhankelijk van het weer. 
- $\quad$ Mest aanwenden onder gunstige weersomstandigheden

- Dit wordt door de adviseurs als een belangrijke maatregel beschouwd.

- Hierbij spelen twee factoren een belangrijke rol: wel/eigen bemester en wel/niet voldoende opslagcapaciteit.

- Boeren die een eigen bemester hebben kunnen makkelijker onder gunstige weersomstandigheden uitrijden dan boeren die afhankelijk zijn van de loonwerker. Veehouders die zelf uitrijden houden dan ook meer rekening met het weer. Echter steeds minder veehouders hebben een eigen bemester vanwege de hoge kosten van deze machines waardoor uitrijden onder gunstige omstandigheden steeds moeilijker wordt. De geïnterviewde loonwerker gaf dat als hij rekening dient te gaan houden met het weer dat hij dan twee uitrij combinaties erbij moet kopen om dat mogelijk te maken en dat het uitrijtarief voor de veehouders dan verdubbeld wordt. Bij uitrijden door de loonwerker met een sleepslangbemester kan bij droog weer wat meer water bij de mest gedaan worden waardoor het nadeel van ongunstige weersomstandigheden minder speelt.

- Bij een deel van de boeren is de (beperkte) opslagcapaciteit leidend voor wanneer mest wordt uitgereden. Aan het eind van het uitrijseizoen moeten de mestopslagen leeg zijn om de winterperiode te kunnen overbruggen. En aan het begin van het uitrijseizoen moet zodra het weer en het land het toelaat mest worden uitgereden omdat de mestopslagen vol zitten. De geïnterviewde loonwerker gaf aan dat hij eerst bij deze boeren (deels zijn dit stopper-boeren) aan de gang gaat en later bij de boeren met meer opslagcapaciteit.

- Een kritiekpunt dat werd genoemd is dat het in de mestwetgeving om de machine gaat en niet om de stikstofbenutting.

- Eén adviseur gaf aan dat je vooral in de periode februari-juni moet bemesten, omdat de mineralisatie later op gang komt. En dat je in het veenweiden gebieden rond 1 juli kan stoppen met bemesten, omdat de mineralisatie na 1 juli zorgt voor voldoende stikstoflevering.

- Dit wordt door de adviseurs als een belangrijke maatregel beschouwd.

- Dit is vooral effectief omdat het simpel, goed toe te passen is en boeren de revenuen zien. Het financiële voordeel zit in een betere grasgroei wat aangetoond is in experimenten en tevens gaven een paar boeren, die het al jaren deden, ook dit voordeel aan.

- Het grootste knelpunt zit hier bij boeren die met een eigen mesttank uitrijden. Verdund uitrijden gaat bij een tank ten koste van de capaciteit en bij vervoer over de weg naar percelen op afstand krijg je te maken met extra transport. Daarentegen laten meer boeren de mest uitrijden door de loonwerker vanwege toename in bedrijfsomvang.

- Bij de eerste snede is verdund uitrijden met de sleepslangbemester al gemeengoed geworden. Bij een sleepslangmester wordt standaard water toegevoegd omdat de mest dan beter 'loopt' waardoor meer kuubs per uur kunnen worden verwerkt. Voor de eerste snede wordt meestal 3 delen mest +1 deel water gedaan, na eerste snede en vooral in zomermaanden wordt steeds meer 50/50 gedaan. Meer dan 50 water lukt bijna niet.

- Bij uitrijden van dunne fractie met een sleepslangbemester is er geen capaciteitsvoordeel door water toe te voegen en daarom willen boeren er geen water bij. Tevens vloeit dunne fractie met water meer uit, waardoor het in bredere stroken terecht komt en je te brede meststroken kan krijgen en je kans loopt op een boete.

- Knelpunt bij het verdund uitrijden is hoe je kunt aantonen dat er voldoende water bij de mest komt.

- $\quad$ Minder eiwit in gras (\& minder eiwit in rantsoen) (minder bemesten of later maaien)

- Minder eiwit in het gras is een maatregel die altijd in combinatie moet worden gezien met het eiwitgehalte in het rantsoen. Deze twee moeten met elkaar in evenwicht zijn. 
- Er liggen mogelijkheden om het ruw eiwitgehalte in het gras te verlagen waarbij rekening dient te worden gehouden met grasproductie en graskwaliteit.

- Een lager eiwitgehalte in het gras kan worden bereikt door later te maaien en/of minder/anders te bemesten.

- Later maaien spreekt boeren minder aan vanwege risico's op slechter weer, kans op ondergras, dat de hergroei belemmert als je het ondergras ook maait, en, naast een lager RE-gehalte, ook een lager VEM-gehalte. Maaien wordt vooral bepaald door de weersomstandigheden. De meeste boeren willen op tijd maaien met een wat langere stoppellengte. Stoppellengte is in de loop der jaren wel langer geworden om een snellere hergroei te krijgen.

- Lager ruw eiwitgehalte in het gras wordt in de praktijk vooral bereikt door minder kunstmestgebruik. Bij de eerste snede willen boeren nog wel de standaard hoeveelheid kunstmest gebruiken, bij latere sneden wil men wel sterk terug.

- Het inkuilmanagement is ook van invloed op de eiwitbenutting. De voeradviseur gaf aan dat je bij een natte kuil een hoog OEB en laag DVE hebt, terwijl je bij een drogere kuil meer DVE en bestendiger eiwit hebt. Door droger in te kuilen kan men een hoger DVE behalen.

- Voor een lager eiwitgehalte in het gras hoeft niet al het gras een laag eiwitgehalte te hebben. Het gaat erom dat je gemiddeld goed in het rantsoen met een lager eiwitgehalte toe kan. De eerste snede moet goede kwaliteit eiwit hebben. Dus niet één bemestings- en maairegime, maar onderscheid maken in percelen, afhankelijk van het maaitijdstip en niveau van bemesting. Perceel specifiek bemesten en maaien dient vertaald worden naar de ruwvoerwinning: welke mest op welke perceel in combinatie met het maairegime en inkuilmanagement bepaalt wat voor ruwvoer je eraf gaat halen. Dat is een puzzel die bedrijfsspecifiek is. Je maakt je rantsoen met het ruwvoer dat van je percelen afkomt plus het voer dat je aankoopt.

- Vanwege de droge periode in 2018 zullen de grasvoorraden zijn afgenomen. De boeren zullen weer meer gras willen oogsten en zullen steviger gaan bemesten. (Het gewenste percentage eiwit van eigen land ( $\geq 65 \%$ ) zal ook hier een rol gaan spelen).

Minder eiwit in mengvoer/rantsoen

- Deze maatregel moet je in combinatie zien met minder eiwit in het gras. Bij het ruw eiwitgehalte gaat het om het totale rantsoen, want mengvoer maakt maar een deel van het rantsoen uit.

- Naast verlaging van het ruw eiwitgehalte in het mengvoer, kan men ook een ander soort eiwit in het mengvoer doen dat beter aansluit bij het OEB en DVE-gehalte van het gewonnen gras. Men kan het ruw eiwitgehalte in het rantsoen beinvloeden door eiwitarmere enkelvoudige grondstoffen te gaan voeren.

- Het ruw eiwitgehalte kan nog omlaag. Echter in het algemeen zijn veevoeradviseurs bang dat de melkproductie onderuit gaat als men het ruw eiwitgehalte verlaagt. Het verlagen van het ruw eiwitgehalte ligt gevoelig vanwege melkproductie en concurrentie van andere mengvoerbedrijven. Om de veevoerindustrie mee te krijgen naar een lager ruw eiwitgehalte is een omslag in denken nodig van meer-meer naar beter \& efficiënter. Aandachtspunt is om reëel te blijven in zaken via haalbare en motiverende zaken. Om in één keer van 180-190 RE naar 145 RE te gaan is een te grote stap. Het werkt motiverender om kleinere stappen te zetten van bijvoorbeeld van 180 naar 170 RE. Tevens zijn veranderingen makkelijker door te voeren als er een goede vertrouwensrelatie is tussen veehouder en adviseur.

- $\quad$ Meer mais bijvoeren

- Meer mais bijvoeren wordt de adviseurs als een weinig zinvolle maatregel gezien voor het veenweiden gebied. Het veenweiden gebied is niet geschikt voor maisteelt en mais voeren vervangt gras, en aangezien men in het algemeen voldoende gras heeft zou mais bijvoeren tot meer grasoverschot leiden.

- Een alternatief zou grasbrok kunnen zijn om een betere eiwitbenutting van het gras te krijgen. Echter er zit geen grasdrogerij in het veenweiden gebied. 
- $\quad$ Andere kunstmest gebruiken

- De redenen dat veehouders een andere kunstmestsoort gaan gebruiken heeft weinig te maken met verlagen van de ammoniakemissie. Argumenten die ze hebben zijn een betere stikstofbenutting en om de eiwitsamenstelling van het gras te beïnvloeden.

- Meer boeren zijn overgestapt van korrel op vloeibare kunstmest. Met vloeibare kunstmest kan je preciezer bemesten doordat het beter te doseren is en wordt eerder opgenomen. En bij droogte heeft men het voordeel dat het niet blijft liggen. Het soort vloeibare kunstmest dat wordt gespoten hangt van de loonwerker af, maar er zijn steeds meer boeren die zelf vloeibare kunstmest inkopen en de loonwerker laten uitrijden.

- $\quad$ Emissiearme stal

- Emissiearme stal wordt gezien door de adviseur als minst belangrijke maatregel. Veehouders passen dit alleen toe bij nieuwbouw vanwege de verplichting om emissiearm te bouwen.

- Een kritiekpunt dat werd genoemd is bij dat emissiearme stallen er niet wordt gekeken naar het integrale plaatje zoals bijvoorbeeld de kwaliteit van de meststof, welzijn, etc. RAV-codes sturen niet op een betere mineralenbenutting (kringlopen).

\subsection{Motieven voor gedragsverandering}

Invloedsfactoren - RESET (enquête)

De tien belangrijkste invloedfactoren die volgens de geënquêteerde melkveehouders van belang voor hen zijn geweest om ammoniak reducerende maatregelen te nemen waren:
1. Masterclasses van Proeftuin Veenweiden
5.29 (Educatie)
2. Eigen waarnemingen (oog, oor, neus)
5.00 (Tools)
3. Groepsbijeenkomst met boeren uit de Proeftuin
4.89 (Educatie) Begeleider van Proeftuin Veenweiden
4.89 (Sociaal)
5. Uitgevoerde analyses (bv voer, bodem, gras)
4.70 (Tools)
6. Regelgeving landelijke overheid (nu en toekomst)
4.54 (Regels)
7. Eigen testen op het bedrijf
4.46 (Educatie)
8. Experimenten van de Proeftuin
4.36 (Educatie)
9. Berekend economisch voordeel
4.32 (Economie)
10. Regels vanuit de melkfabriek (nu en toekomst)
4.23 (Regels) De uitslag van de KringloopWijzer
4.23 (Tools)

De vijf minst belangrijkste invloedsfactoren die volgens de geënquêteerde melkveehouders van belang voor hen zijn geweest om ammoniak reducerende maatregelen te nemen waren:
1. Advies van de accountant
2.11 (Sociaal)
2. Bericht op sociale media (o.a. twitter, Facebook)
2.36 (Sociaal)
3. Loonwerker
2.60 (Sociaal)
4. Open dag bij een boer
2.65 (Educatie)
5. Beleid van gemeente en provincie
2.91 (Regels)

\section{RESET volgens adviseurs}

\section{- Regels}

- De wetgever is een belangrijke invloedfactor voor gedragsverandering, want als iets verplicht wordt moeten er wel stappen ondernomen worden.

- Soms is het ook wachten op regelgeving voordat men gaat investeren, omdat je anders in verkeerde dingen kan hebben geïnvesteerd.

- Regels van de zuivelindustrie raakt boeren in de portemonnee.

- $\quad$ Educatie

- Pilot-boeren vind het leuk om nieuwe dingen te doen en kennis op te doen. Volgerboeren willen weten dat iets werkt voordat ze het toepassen. 
- Bij kennis is het belangrijk om te laten zien dat iets kan, om de angst weg te nemen of om te tonen dat iets niet kan en men er geen nadelen van ondervindt.

- Belangrijkste zijn 1-op-1 gesprekken en studiegroepen. De combinatie van gesprekken en groepen is belangrijk.

- Groepsbijeenkomsten zijn essentieel voor kennisoverdracht en ook om te laten zien dat iets werkt in de praktijk bij een veehouder. Dat overtuigt meer. Dus ook kijken bij andere veehouders. Sommige veehouders laten zich meer overtuigen door andere collega's, dan door adviseurs.

- Sociaal

- De veevoeradviseurs zijn de belangrijkste beïnvloeders van de boeren.

- De veevoeradviseur is een belangrijke invloedfactor.

- Collega veehouders als boeren daarmee sparren.

- Vrouw van de boer is een belangrijke factor om rekening mee te houden om het gedrag van boeren te veranderen.

- Sociaal is bij doorsnee boeren belangrijker. Deze willen kunnen zien dat het bij anderen werkt. Pilot-boeren kijken veel minder of het bij anderen kan, hebben een hogere eigen drive om zaken te veranderen.

- Pilot-boeren zijn omgevingsbewuster, grotere maatschappelijkere betrokkenheid.

- Het zien bij andere boeren en voorlichtingsavonden voor boeren.

- Bij samenwerkingsverbanden moet iedereen wel achter de verandering staan.

- Als andere sectoren niks hoeven te doen (zoals bijvoorbeeld luchtvaart en scheepvaart bij reductie broeikasgassen) en de veehouderij wel, dan werkt dat niet motiverend.

- Laten zien dat optimalisatie van de bedrijfsvoering leidt tot gunstiger uitkomsten met ammoniakemissie.

- $\quad$ Economie

- Hoewel economie als belangrijke driver wordt gezien is geld niet altijd een driver voor gedragsverandering. Ook al blijkt uit voorrekening dat een bepaalde verandering geld gaat opleveren wil niet altijd zeggen dat de verandering ook daadwerkelijk doorgevoerd gaat worden.

- Tools

- Pilot-boeren hebben meer interesse om met tools en cijfers te werken dan volgerboeren. Voor volger-boeren moet het meer praktisch blijven en op de dagelijkse bedrijfsvoering gericht zijn. Tools wordt door volger-boeren meer uitbesteed.

Beïnvloeders van de geïnterviewde melkveehouders

De geïnterviewde veehouders gaven de volgende zaken aan als datgene/diegene die hun keuzes beïnvloedt m.a.w. de belangrijke informatiebronnen/beïnvloeders voor hen.

- Personen

- Familie: vrouw, vader

- Partner

- Collega's: andere melkveehouders, pilotboeren

- Adviseurs: PPP Agro Advies, voeradviseur, veearts, bodemadviseur, waarbij een veehouder aangaf dat een vertrouwde adviseur een must is om veranderingen door te voeren

- Nieuwe denkers

- Kennisbijeenkomsten

- Studieclub(s) waar men in deelneemt

- Proeftuin Veenweiden: groepsbijeenkomsten, Masterclass bijeenkomsten, Projectleiders

- Sprekers op bijeenkomsten

- Agrarische natuurvereniging

- Kennisbronnen

- Vakbladen: waarbij wel soms werd aangegeven dat je dient op te letten en na te denken of e.e.a. wel klopt in een artikel

- KTC Zegveld

- VVBM

- Informatie op internet 
- $\quad$ Eigen inzicht en ervaring

- Cijfers zien die overtuigen

- Tools: Excel, Feedwedge en Farmwalk

- Bedrijfsplan proeftuin

De belangrijkste beïnvloeders zijn: familie, collega melkveehouders, adviseurs en studieclubs, die allemaal in het persoonlijke contact liggen. Echter er bleek ook een grote variatie te zijn in wijze waarop boeren zich laten beinvloeden. De één wordt wel beïnvloed door zijn vrouw, terwijl bij een ander dat niet het geval is. Bij de één is de onafhankelijke adviseur belangrijk, terwijl bij ander de voeradviseur dat is. Bij collega's melkveehouders zijn het regelmatig specifieke boeren waarmee ze zaken bespreken of kunnen spiegelen. Ook bij de vakbladen zit er grote variatie in wat men een blad met goede informatie vindt. En in sommigen gevallen ervaarde men een familielid of de voeradviseur als een negatieve beïnvloeder vanwege het slecht willen meewerken als het ging om veranderingen door te voeren.

Belangrijkste kennisbronnen van de geënquêteerde veehouders In figuur 2 staat de procentuele verdeling aangeven van de antwoorden op de vraag wat men de drie belangrijkste kennisbronnen voor de veehouder zijn.

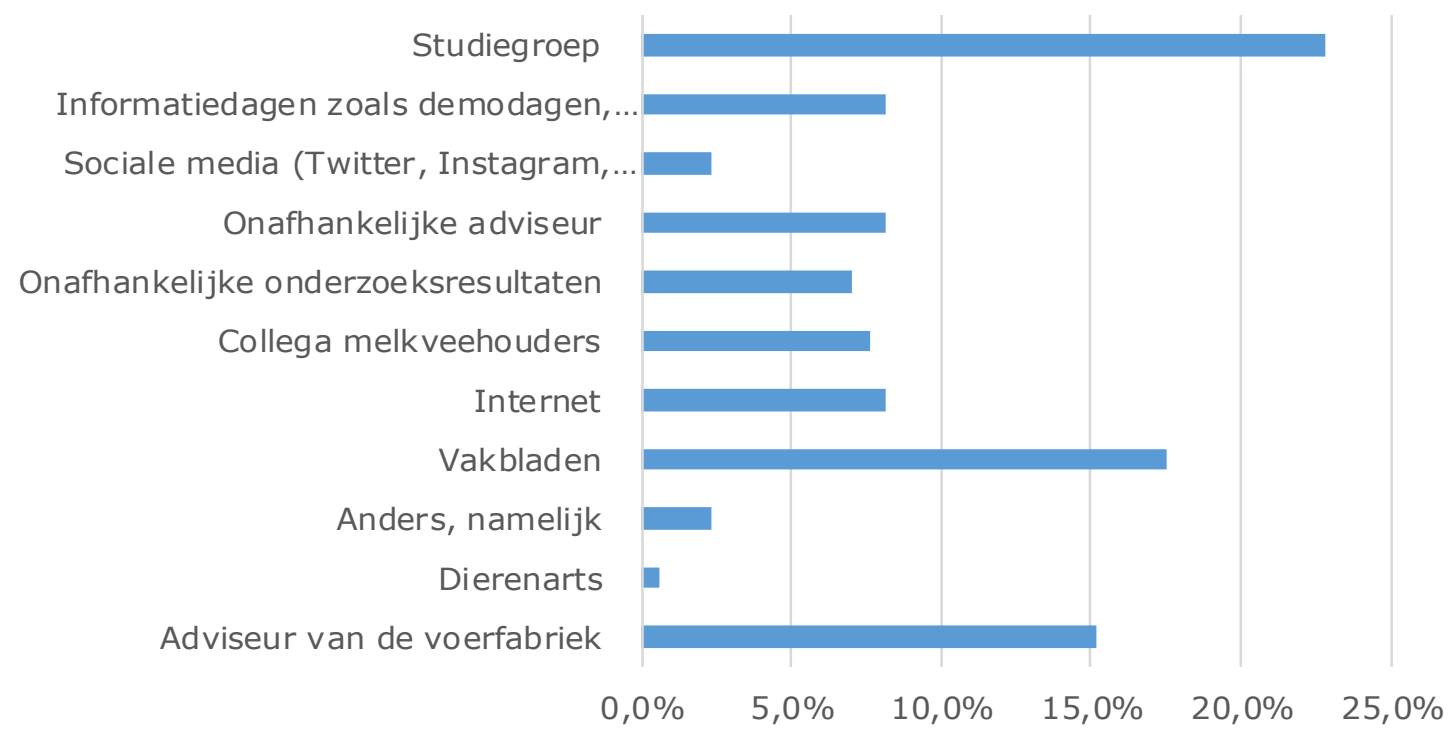

Figuur 2 Procentuele verdeling van de belangrijkste kennisbronnen van de geënquêteerde melkveehouders o.b.v. een respons van 57 van de 97 veehouders uit de Proeftuin Veenweiden.

De drie meest genoemde belangrijkste kennisbronnen waren:
1. Studiegroep
2. Vakbladen
3. Adviseur van de voerfabriek

Kwartjesmomenten van de geïnterviewde melkveehouders

De volgende zaken werden aangegeven dat men ervaarde dat er een kwartje viel, tot nieuwe inzichten kwam of een leermoment had:

- $\quad$ Minder stikstofaanvoer (lager RE-gehalte) zorgt ervoor dat je minder stikstof met de mest hoeft af te voeren waardoor je meer fosfaat uit mest over houdt voor bemesting van je eigen land.

- $\quad$ Boer die echt buiten de gebaande paden durft te gaan.

- Dat een lager ruw eiwit en meer structuur gezondere koeien geef.

- Artikelen van de vereniging VBBM: Jaap van Bruchem.

- De waarschuwing voor de mogelijke gevolgen van ammoniak (minder vee).

- Inzicht dat beweiden zorgt voor verlaging van de ammoniakemissie (wil meer gaan beweiden). 
- $\quad$ Privé situatie die leidde tot een omslag in denken om meer de balans te gaan zoeken in het bedrijf: koe in balans (fokkerij), eiwit-energie in balans (rantsoen), bemesting-bodem.

- Te ver teruggegaan met fosfaat in het rantsoen.

- Andere stal met andere vloer nodig want huidige emissiearme stallen zijn geen goede systemen (stal met gescheiden urine en mest nodig i.p.v. huidige ammoniakarme stallen).

- Masterclass Voer waarin een WUR-wetenschapper, die alles had uitgezocht over ruw eiwit gehalte in het rantsoen, liet zien hoe laag je met het ruw eiwitgehalte kan gaan.

- Bewuster met de materie bezig, nieuwe materie nog mee leren om te gaan.

- Bijeenkomsten met andere boeren.

- Whatsapp-groep.

\section{Leermomenten van de adviseurs}

De volgende zaken werden door adviseurs aangegeven als belangrijke leermomenten voor hun:

- Inzichten in de PAS uit een presentatie tijdens een bijeenkomst van de Proeftuin Veenweiden.

- Dat het mogelijk is om bij de sleepvoet met water de gewenste ammoniakreductie te halen.

- Doorrekeningen van de bedrijfsplannen om het effect van de maatregelen op kilogrammen ammoniakemissie wat inzichtelijk maakte dat $25-30 \%$ reductie goed mogelijk was. De bedrijfsplannen waren heel belangrijk voor de begeleiders om het gevoel te krijgen dat $25 \%$ mogelijk was. Bottleneck zit nog bij het voer om de $25 \%$ te halen.

- $\quad$ Stalemissie (ton melk of evt. GVE) en veldemissie (per ha) uit elkaar trekken om zo intensief en extensief goede doelen te kunnen behalen. Winst die tot nu behaald is, komt vooral door reductie in veldemissie.

- Eyeopener was dat ze zien dat in BEX goed wordt gescoord op fosfaat, maar niet op stikstof. Dat was een inzicht dat ze wat met ruw eiwit moesten gaan doen. Dus vanuit BEX is dan voordeel te halen als ze men wat gaan doen met ruw eiwit.

- De Masterclass Ruw eiwit: gesprekken met adviseurs/begeleiders en pilot-boeren gekeken naar hoe het ruw eiwit in het rantsoen omlaag gebracht kon worden. De $1^{\mathrm{e}}$ bijeenkomst met Jan Dijkstra (WUR) nog niet veel impact. De $2^{\mathrm{e}}$ bijeenkomst met begeleiders \& adviseurs waar de nadruk veel meer lag op noodzaak toen kwam wel goed aan bij de veehouders.

\section{Kennisbronnen van adviseurs}

$\mathrm{Er}$ is groot scala aan kennisbronnen die adviseurs gebruiken om hun kennis te vergroten. Elke adviseur heeft wel zo eigen specifieke kennisbronnen en netwerk.

Kennisinstellingen:

- Wageningen UR: bijeenkomsten, onderzoekers, onderzoeksverslagen

- VIC Zegveld

- Schothorst

- $\quad$ Bijeenkomsten van de Kringloopwijzer

Media:

- Vakbladen: elke adviseurs heeft zo eigen voorkeur voor specifieke vakbladen

- Internet: achtergrondinformatie, onderzoeksrapporten, artikelen

Brancheorganisaties

- Nevedi

- Cumela: bijeenkomsten en nieuwsbrieven

- LTO: bijeenkomsten

Bedrijfsleven

- Leveranciers waar men producten/diensten vanaf neemt

- $\quad$ Bedrijven waarmee samengewerkt wordt

- $\quad$ Specialisten uit het bedrijfsleven 


$\begin{array}{cl}\text { Adviseurs: } & \\ \bullet & \text { Collega adviseurs } \\ \bullet & \text { Onafhankelijke adviseurs } \\ \text { Sociaal } & \\ \bullet & \text { Familie } \\ \bullet & \text { Vrienden } \\ \bullet & \text { Veehouders die men begeleidt } \\ \text { Tools } & \\ \bullet & \text { Data die men verzamelt }\end{array}$

\subsection{Belemmeringen}

De vijf relatief meest belangrijke belemmeringen die de geënquêteerde melkveehouders ervaren, o.b.v. een respons van 57 van de 97 veehouders uit de Proeftuin Veenweiden, om (nog meer) veranderingen in hun bedrijfsmanagement door te voeren om de ammoniakuitstoot te verminderen waren.

1. Wet- en regelgeving

2. Andere dingen op mijn bedrijf zijn belangrijker

3. Mijn bodemgesteldheid geeft beperkingen in de bedrijfsvoering Het weer geeft beperkingen in de bedrijfsvoering

4. Onderwaterdrainage is te duur

Belemmeringen (interview melkveehouders)

De volgende zaken werden aangegeven als meest belemmerd om veranderingen door te voeren:

- Wet- en regelgeving:

- Regels waarbij je niet echt weet waar je aan toe bent zoals met de mestwetgeving en leveringsquotum van de melkfabriek.

- Wetgeving rondom ruige mest: voordelen van ruige mest worden te weinig belicht vanwege kwijtraken kennis rondom ruige mest.

- Fosfaatregelgeving vanwege de grote financiële lasten die daarmee gepaard kunnen gaan.

- Overbodige administratie waar je niks aan hebt voor je bedrijf.

- Onduidelijkheden bij het invullen van KringloopWijzer.

- Melkfabriek: werkt eerder remmend dan stimulerend.

- Financiën: financiële beperkingen t.a.v. van nieuwe investeringen in het bedrijf.

- Huiskavel: kleine huiskavel en indeling van de huiskavel.

\section{Belemmeringen voor veehouders volgens adviseurs}

De volgende zaken werden aangegeven door de adviseurs als belemmeringen voor veehouders om veranderingen door te voeren:

- Financieel

- Levert een verandering wel geld op of kost het alleen maar geld.

- Investeringskosten.

- Ontbreken van beloningen voor voorlopers c.q. het halen van doelen.

- Boeren letten te veel op kosten, en niet op wat je overhoudt onder de streep.

- Wet- en regelgeving

- Angst voor nog meer verplichting. Men wil geen standaard zetten voor andere veehouders.

- Sectordoelen zijn probleem van de sector, niet van de individuele boer.

- Overheid is niet ingesteld op innovatieve boeren.

- Overheid werkt aan oplossingen voor single issues, en werkt niet integraal over meerdere issues.

- Kennisoverdracht

- Integrale bedrijfsvoering ontbreekt vaak in de kennisoverdracht. 
- Veel adviseurs komen maar voor één onderdeel van de bedrijfsvoering, waarbij ook commerciële belangen een rol spelen.

○ Voeradviseurs: nog teveel gericht op maximalisatie i.p.v. optimalisatie.

- Sociaal

- Risicomijdend gedrag: als zaken goed lopen waarom zou je dan gaan veranderen, want levert risico en gedoe op.

- Oude generatie die wil door blijven boeren zoals ze altijd hebben gedaan en belemmert de volgende generatie om veranderingen door te voeren.

- Weer

- Invloed van weer op samenstelling vers gras en kuilgras.

\subsection{Communicatie-activiteiten van de proeftuin}

Van de communicatie-activiteiten uit de proeftuin hebben met name de studiegroepbijeenkomsten, de masterclasses en de experimenten bruikbare kennis voor de veehouders opgeleverd. De volgende orde van belangrijkste naar minste belangrijke communicatieactiviteit is als volgt:

1. Studiegroepbijeenkomsten

2. Pilotboer: Masterclassen

3. Pilotboer: Experimenten

4. Themasessies voor melkveehouders, bedrijfsadviseurs, stakeholders, onderzoekers en beleidsmakers

5. Nieuwsberichten via de pers

6. Digitale nieuwsbrief

7. Pilotboer: Whatsapp-groep

8. Campagne Op Grond Van Morgen

In bijlage 10 staan de toelichtingen die de veehouders hebben gegeven over waarom bepaalde kennis wel/niet bruikbaar was.

\section{Communicatie-activiteiten die volgens de adviseurs veel impact hebben gehad}

- Masterclasses waren een hele goede: gemotiveerde boeren + goede kennis binnenhalen, sparren met deskundigen door boeren waardoor kwartjes vielen. Bij volger-boeren zal dit minder werken. Er moet een goede combi zijn met de deskundige die aansluit bij de groep.

- Masterclasses waren heel belangrijk en positief voor de pilot-boeren, vanwege het opdoen van nieuwe kennis en het onderling delen van kennis. Er kon ook specifieker op bedrijfssituatie bij boeren worden in gegaan en er zat een stukje coaching bij in.

- Studiegroepen: inhoudelijk tandje lager, low-profile, lager niveau. Belangrijkste punten zijn allemaal wel besproken. Goede opzet door pilot-boer in een studiegroep volgers.

- $\quad$ Experimenten was ook een hele leuke communicatieactiviteit. Het waren geen wetenschappelijk opgezette experimenten. Het maakt dingen zichtbaar voor veehouders waardoor men over dingen na gaat denken. Resultaten van de experimenten werden gecommuniceerd via nieuwsberichten \& website.

- Website is ook belangrijk geweest in de communicatie.

- WhatsApp: houden de aardigheid erin, vooral leuk voor de 10 pilot-boeren om elkaar te triggeren, dagelijkse bedrijfsvoering kwam ter sprake zoals momenten van maaien, bemesten, beweiden, etc. Heeft goed gewerkt.

- App mest uitrijden gunstig weer: leuk idee, maar geeft gevoel dat je niet weet wanneer je zou moeten bemesten. App zit aan irriterende kant (gehoord van boeren), geen stimulans. 


\subsection{Projectevaluatie}

Positieve ervaringen van de geïnterviewde melkveehouders in de Proeftuin

Er werden tijdens de interviews verschillende positieve ervaringen aangehaald, waarbij sommige ervaringen door meerdere veehouders benoemd werden en sommige alleen door één veehouder. De volgende positieve ervaringen zijn tijdens de interviews benoemd met bijbehorende redenen:

- Mest verdund uitrijden met water: betere grasgroei, arbeidsbesparing, betere smakelijkheid van het gras, betere balans op het bedrijf, kunstmestgift kan omlaag.

- Bijeenkomsten van de proeftuin: bomen met collega's over dilemma's om nieuwe dingen van te leren.

- Verlaging van het ruw eiwitgehalte in het rantsoen: weten dat het mogelijk is, dat je verder kan zakken dan je dacht, gezondere koeien, betere voerbenutting.

- Langer weiden: meer weiden en toch productie op peil kunnen houden.

- Gebruik van vloeibare kunstmest: steviger gras.

- Sturen op ureumgehalte: zien dat je er wel op kan sturen.

In bijlage 11 staat de lijst met zaken aangegeven waar de geënquêteerde veehouders tevreden over waren in de Proeftuin Veenweiden.

Negatieve ervaringen van de geïnterviewde melkveehouders in de Proeftuin in de Proeftuin De volgende negatieve ervaringen zijn tijdens de interviews benoemd met de redenen die zijn genoemd:

- Mest beluchten: suggesties dat het een effectief systeem is maar blijkt niet overal zelfde effect te hebben.

- Voeradviseur wil niet geheel meewerken: moeilijk om een brok op maat te maken.

- Whatsapp-groep: niet altijd antwoord krijgen op je vragen.

- $\quad$ Capaciteit bij loonwerker onvoldoende: loonwerkers hebben niet de capaciteit om altijd met perfecte omstandigheden en bodemtemperatuur uit te rijden.

- Weer: spelbreker bij goed implementeren van maatregelen.

- $\quad$ Later maaien: ging ten koste van de graskwaliteit.

- Verlaging van het ruw eiwitgehalte: de verlaging leidde ook tot een lager fosforgehalte in het voer wat i.c.m. met een laag PAL-gehalte van de grond leidde tot een fosforgebrek bij droge koeien waardoor monocalciumfosfaat aan het rantsoen moest worden toegevoegd voor een hoger fosforgehalte in het rantsoen en de mest (fosfaatkunstmest mag niet worden gebruikt vanwege derogatie), aanpassingen rantsoen verliepen niet vlekkeloos wat melkgeld heeft gekost.

- Bemesten op bodemtemperatuur: mooi getal maar niet al te praktisch.

- Huidige ammoniakarme stallen: zijn geen goede systemen want bedrijfsvoering draait om meer dan alleen ammoniakemissie uit de stal.

- Teveel aannames in de KringloopWijzer: stikstof leverend vermogen van veen is onvoldoende specifiek en verhouding VEM/eiwit in het rantsoen klopt niet altijd.

In bijlage 11 staat de lijst met zaken aangegeven waar de geënquêteerde veehouders ontevreden over waren in de Proeftuin Veenweiden.

Tips van de geïnterviewde melkveehouders voor het project

De volgende tips voor het project Proeftuin Veenweiden zijn gegeven tijdens de interviews:

- $\quad$ Begeleiding

- Persoonlijke begeleiding is voor volgers ook relevant, niet alleen voor pilot-boeren.

- Whatsapp: vragen die onbeantwoord blijven, zouden door adviseurs beantwoord dienen te worden.

- Communicatie

- Publiceer elke maand in vakbladen met eenvoudige en duidelijke artikelen. Zorg dat de kern duidelijk is.

- Boeren die niet meedoen met de proeftuin bereiken door kennis. Kennis moet verspreid worden door herhaling; korte filmpjes waarin veehouders hun verhaal doen. 
- Probeer om hetzelfde te doen als wat bij beweiding is gebeurd: nu moet je uitleggen waarom je niet beweidt terwijl dat vroeger andersom was.

- Er moet een kanteling in het denken komen om verandering in de massa te krijgen (vergelijkbaar als met roken).

- Boeren laten zien dat het bij anderen goed gaat.

- Techniek word al snel tegen de boer gebruikt. Denk daarom goed na welke informatie de wereld in mag.

- Voel aan waar boeren zitten, hoe ver ze zijn met hun denken als je wat vertelt.

- Ga boeren niet vertellen wat ze wel/niet moeten doen.

- Innoveren

- EC-meter op bemester zodat je precies duidelijk is hoeveel de mest is verdund.

- I.p.v. een EC-meter misschien beter om gebruik te maken van DS-meter

- Overig

- Innovators zijn zo ver vooruit dat gewone bedrijven dat niet meer kunnen bij houden.

- Niet te ver vooruit gaan lopen op zaken.

- De veevoerindustrie adviseert (nog) te veel ruw eiwit in het voer. Als je die om krijgt naar lager ruw eiwit in het rantsoen kan je veel winnen.

- Proeftuin gebruiken als klankbordgroep naar de overheid.

- Als er negatieve effecten zijn voor voorlopers zoals in de proeftuin, dan de moeten gevolgen gecompenseerd worden door de sector (soort van calamiteitenfonds).

In bijlage 11 staat de lijst met tips van de geënquêteerde veehouders voor de Proeftuin Veenweiden weergegeven.

Tips van adviseurs voor het project

- Je moet stimuleren en niet irriteren.

- De piramide: pilot-volger-peloton is goed bevallen in het project. Er kan nog wel wat worden geïnvesteerd in de peloton-boeren door avonden te organiseren en te vertellen wat eruit komt bij de pilot-boeren.

- De pilot-boer is nog teveel de focus in volger-groep. De focus zou ook wat meer mogen liggen bij volger-boeren onderling met de resultaten die ze halen.

- Ga met een top tien maatregelen aan de slag die integraal werken in de bedrijfsvoering, en stoppen met factsheets over één onderwerp.

- Gebruik cijfers van metingen om te overtuigen. Meetcijfers worden nog te weinig gecommuniceerd naar veehouders.

- Misschien ook masterclasses organiseren voor volger-boeren, maar dan wel opsplitsen in meerdere groepen want 100 man is te veel voor één groep. De kracht van de masterclass is zowel input van buitenaf als input van de veehouders. 


\section{Discussie}

\section{Representativiteit van het onderzoek}

De melkveehouders uit de Proeftuin Veenweiden kunnen niet worden beschouwd als de gemiddelde doorsnee melkveehouder, ook niet voor het veenweidegebied. Dit komt doordat de melkveehouders zichzelf hebben aangemeld om deel te nemen aan de Proeftuin Veenweiden en dat vanuit interesse en/of belang van het onderwerp voor hun bedrijfsvoering zullen hebben gedaan. Daarbij betreft het melkveehouders uit een specifieke regio van Nederland. De resultaten van het onderzoek kunnen daarom niet zomaar 1 op 1 worden vertaald naar geheel Nederland.

$\mathrm{Er}$ is een beperkte groep van 10 melkveehouders geïnterviewd en de respons op de internet enquête was $57 \%$. Gezien deze respons en kwalitatieve verdieping via de interviews mag verwacht worden dat de resultaten een goed beeld geven van de deelnemende veehouders aan de Proeftuin Veenweiden.

Er zijn diverse adviseurs geïnterviewd, die begeleiden binnen de Proeftuin en daarbuiten. Veel veehouders hebben aangegeven dat ze ook veel inspiratie opdoen in studieclubs die los staan van de Proeftuin. De resultaten zijn daarom een gevolg van communicatie activiteiten vanuit de Proeftuin, maar ook van bijeenkomsten daarbuiten.

Uit de interviews en enquête is geleerd wat pilotboeren en volgerboeren stimuleert en belemmert in een Proeftuin met veel begeleiding. De vraag is hoe je de achterblijvers stimuleert om milieumaatregelen te nemen zonder veel begeleiding. Daarvoor zijn algemene lessen verwoord bij de aanbevelingen en hoofdstuk Synthese en reflectie. 


\section{$5 \quad$ Conclusies en aanbevelingen}

\section{$5.1 \quad$ Conclusies}

Er zijn belangrijke verschillen tussen pilotboeren en volgerboeren wat betreft de reden van gedragsverandering. Pilotboeren zoeken uitdagingen en nieuwe dingen op, terwijl volgerboeren willen leren van het project en weten wat de impact is op hun bedrijfsvoering. Dit uit zich ook in de manier van ondersteuning die ze zoeken: pilotboeren willen gecoacht worden, terwijl volgerboeren geadviseerd willen worden. Daarbij hebben pilotboeren een beter beeld waar ze naar toe willen met het bedrijf, terwijl volgerboeren meer gericht zijn op de dagelijkse bedrijfsvoering. Verder is de variatie in type ondernemer bij de volgerboeren groter.

Het toepassen van de volgende ammoniak reducerende maatregelen is tijdens proeftuin Veenweiden volgens de respons van de geënquêteerde veehouders als volgt toegenomen:

- Minder jongvee aanhouden:

- Meer beweiden:

- Mest uitrijden bij gunstig weer:

- Mest verdund uitrijden:

- Minder eiwit in het gras winnen:

- Minder eiwit in het rantsoen:

van $14 \%$ naar $88 \%$
van $49 \%$ naar $72 \%$
van $16 \%$ naar $76 \%$
van $25 \%$ naar $95 \%$
van $4 \%$ naar $49 \%$
van $9 \%$ naar $79 \%$

De redenen waarom men wel of niet een bepaalde maatregel is gaan toepassen verschilt sterk tussen maatregelen. Het merendeel van de veehouders verwacht de komende jaren de maatregelen te blijven toepassen.

De vijf belangrijkste invloedfactoren, die volgens de geënquêteerde melkveehouders van belang voor hen zijn geweest om ammoniak reducerende maatregelen te nemen, waren:

1. Masterclasses van de proeftuin

2. Eigen waarnemingen (oog, oor, neus)

3. Groepsbijeenkomsten met boeren uit de Proeftuin

4. Begeleider van de Proeftuin

5. Uitgevoerde analyses (bijv. voer, bodem, gras)

De drie belangrijkste kennisbronnen voor de geënquêteerde melkveehouders waren studiegroep, vakbladen en de adviseur van de voerfabriek.

Wet- en regelgeving ervaren de geënquêteerde melkveehouders als belangrijkste belemmering om (nog meer) veranderingen in hun bedrijfsmanagement door te voeren om de ammoniakuitstoot te verminderen.

De masterclasses, studiegroep bijeenkomsten en de experimenten werden het best gewaardeerd van de communicatie-activiteiten uit de proeftuin. 


\subsection{Aanbevelingen}

Uitgebreide aanbevelingen zijn gedaan in hoofdstuk Synthese en reflectie, waarbij resultaten uit dit onderzoek ook gereflecteerd zijn aan meningen uit het projectteam en aanvullende voorlopige cijfers.

Suggesties hoe je de invloedfactoren (RESET) beter in kunt zetten zijn samengevat in onderstaand schema.

\section{Schema Suggesties om invloedfactoren beter in te zetten}

Suggesties

\section{Regelgeving}

Druk uitoefenen via wetgeving werkt goed bij achterblijvers

De Zuivelindustrie vooral meer regie laten nemen

Zorgen voor integrale wetgeving die meerdere doelen nastreeft, niet teveel middelvoorschriften en stuurt op bedrijfsniveau

Proeftuin gebruiken als klankbord naar de overheid

\section{Educatie/kennis}

Leg uit waarom maatregelen nodig zijn en geef inzicht in mogelijkheden (wat kan) waarbij je aansluit op de vaktechnische drive die alle melkveehouders hebben

Werk doelgroepgericht; bijvoorbeeld intensief / extensief, regio, grondsoort, voorlopers / volgers. Bijvoorbeeld masterclass heeft goed gewerkt voor pilotboeren vanwege input van buitenaf en input van veehouders. Pas opzet aan doelgroep aan

Zet kennisbronnen in die passen bij die doelgroep en wees alert op de valkuilen

Melkveehouders niet ontzorgen (door bijvoorbeeld administratie over te nemen), maar assertiever maken bijvoorbeeld naar adviseurs en naar hunzelf door kritischer naar eigen bedrijfsvoering te kijken (oog, neus, oor / analyses voer, bodem, gras)

Werk met basis kengetallen die voor iedereen gelijk is; stuur op de juiste kengetallen met realistische doelen Maak geen eenheidsworsten in de sector; zorg voor variatie in oplossingsrichtingen die passen bij ondernemer en onderneming; dit vergroot ook de kans op leren van elkaar

Benut de natuurlijke variatie van percelen meer qua kansen voor water- en natuuropgaven (Kansenkaarten zijn in ontwikkeling), beweiden, bemesting graslandmanagement, ed. Dat betekent maai- en bemestingsregimes meer variëren

KTC Zegveld moet goede balans maken tussen innovatief (vooruitstrevend) en dagelijkse praktijk; voor sommige boeren sluit het te weinig aan bij de praktijk

Ga aan de slag met een top 10 maatregelen die integraal werken in de bedrijfsvoering, beperk (of stop zelfs)

factsheets over één onderwerp

\section{Sociale druk}

Druk uitoefenen via adviseurs werkt goed bij volgerboeren

Druk uitoefenen bij adviseurs via pilotboeren werkt goed

\section{Economie}

Stimuleer voldoende mestopslag waardoor de flexibiliteit in mest uitrijden op het juiste moment toeneemt

Stimuleer om dezelfde reden voldoende capaciteit bij loonwerkers. Duidelijkheid in regelgeving is nodig alvorens loonwerkers investeren (bijvoorbeeld bij borging verdunnen mest of verbod op sleepvoet)

Beloon goed gedrag (melkpremie, experimenteerruimte, bedrijfsvergroting, inzicht geven in risico's, investeringssubsidies)

\section{Tools}

Maatregelen doorrekenen in bedrijfsplannen en evalueren door te benchmarken met anderen werkt goed

Kringloopwijzer vernieuwen op de volgende punten:

- niet alleen richten op analyse maar ook op planning

- niet alleen richten op jaarlijkse cijfers maar ook op dagelijkse bedrijfsvoering

- niet alleen richten op totaal ha's, maar werk perceelsgericht

Maak een 'KLW-light', dat betekent een versie met minder informatie

Dit betekent dat het wenselijk is versie te ontwikkelen die meer diepgang geven, maar ook die simpeler zijn 


\section{Literatuur}

Bemelmans-Videc, M.L., R.C. Rist and E.O. Vedung (eds.). 2003. Carrots, sticks and sermons: Policy instruments and their evaluation. Transaction Publishers, Piscataway.

De Lauwere, C., E. Oosterkamp, B. Smit, M. Vrolijk en A. Breukers. 2017. Beleidsinstrumenten voor energie-neutrale en klimaatvriendelijke agrosectoren: zoektocht naar de optimale instrumentenmix. Wageningen: Wageningen Economic Research. Rapport 2017-108.

DZK, 2017. Gedetailleerde doelen Duurzame Zuivelketen. Duurzame Zuivelketen, Den Haag. Jansen, J., R. Wessels, en T. Lam. 2012. How to R.E.S.E.T. farmer mindset? Experiences from the Netherlands. In: Countdown Symposium, Melbourne Australia 19 July 2012. - Melbourne Australia: Dairy Australia - p. 23-27.

Michie, S., M. M. van Stralen, en R. West. 2011. The behaviour change wheel: a new method for characterising and designing behaviour change interventions. Implementation Science 6 (42). DOI: $10.1186 / 1748-5908-6-42$. 


\section{Bijlage 1 Vragenlijst interviews melkveehouders}

De opzet van de interviews bestond in hoofdzaak uit drie onderdelen ( $B, C \& D)$, voorafgaand door een algemene vraag $(A)$.

A. Waarom hebt u zich aangemeld?

B. Tijdlijnmethode voor de Proeftuin Veenweiden

a) Welke gebeurtenissen/mijlpijlen zijn er geweest op uw bedrijf in het kader van de Proeftuin Veenweiden?

b) Wat waren positieve momenten, en waarom?

c) Wat waren negatieve momenten, en waarom?

d) Wat waren leer/inzicht momenten, en waarom?

Wat had u meer of minder willen doen in 2017 of 2018, en waarom?

C. Netwerk van de melkveehouder

Wie of wat beïnvloedt uw keuzes? M.a.w. wat zijn belangrijke informatiebronnen/beïnvloeders?

(Denk aan: personen, media, tools, regelgeving)

a) Overzicht netwerk melkveehouder

b) Positieve beïnvloeders

c) Negatieve beïnvloeders

d) Neutrale beïnvloeders

e) Bij wie vallen de meeste kwartjes, wie is de grootste beïnvloeders

Van wie of wat heeft $u$ het meest geleerd?

D. Typering/doelen/leerstijlen

1) Wat betekent een duurzame melkveehouderij voor uw bedrijf? M.a.w. welke duurzaamheidsaspecten zijn voor uw belangrijk? En hoe verhoudt dit zich tot het doel(en) dat u voor ogen hebt met uw bedrijf?

2) Op welke duurzaamheidsaspecten scoort $u$ al goed en op welke is nog een duidelijke verbetering mogelijk?

3) Wat zijn de komende jaren belangrijke veranderingen voor uw bedrijf om de duurzaamheidsdoelen te bereiken of te behouden?

4) Hoe belangrijk is verminderen van ammoniak emissie in dit veranderingsproces?

5) Waardoor wordt $u$ het meest belemmerd om veranderingen door te voeren?

6) Wat geeft u de meeste zorgen?

7) Wat geeft u de meeste voldoening?

8) Welke tips heeft u voor collega melkveehouders?

9) Welke tips heeft u voor het project Proeftuin Veenweiden? 


\section{Bijlage 2 Vragen internet enquête}

\section{Algemeen}

1. Wat is uw naam? Deze vraag is niet verplicht, alleen als u mee wilt dingen naar een kadobon. Als u uw naam invult kunnen we uw bedrijfsgegevens koppelen aan deze enquête. De resultaten worden anoniem verwerkt.

2. Wat is uw woonplaats?

3. Bent u één van de tien pilotboeren?
a. Ja
b. Nee

4. Wat is uw laatst voltooide opleiding?
a. LBO
b. $M B O$
c. $\mathrm{HBO}$
d. WO

5. Wat is uw leeftijd? (in jaren)

\section{Landelijke doelen}

6. Hoe belangrijk vindt u de doelen van Duurzame Zuivelketen voor uw bedrijf?

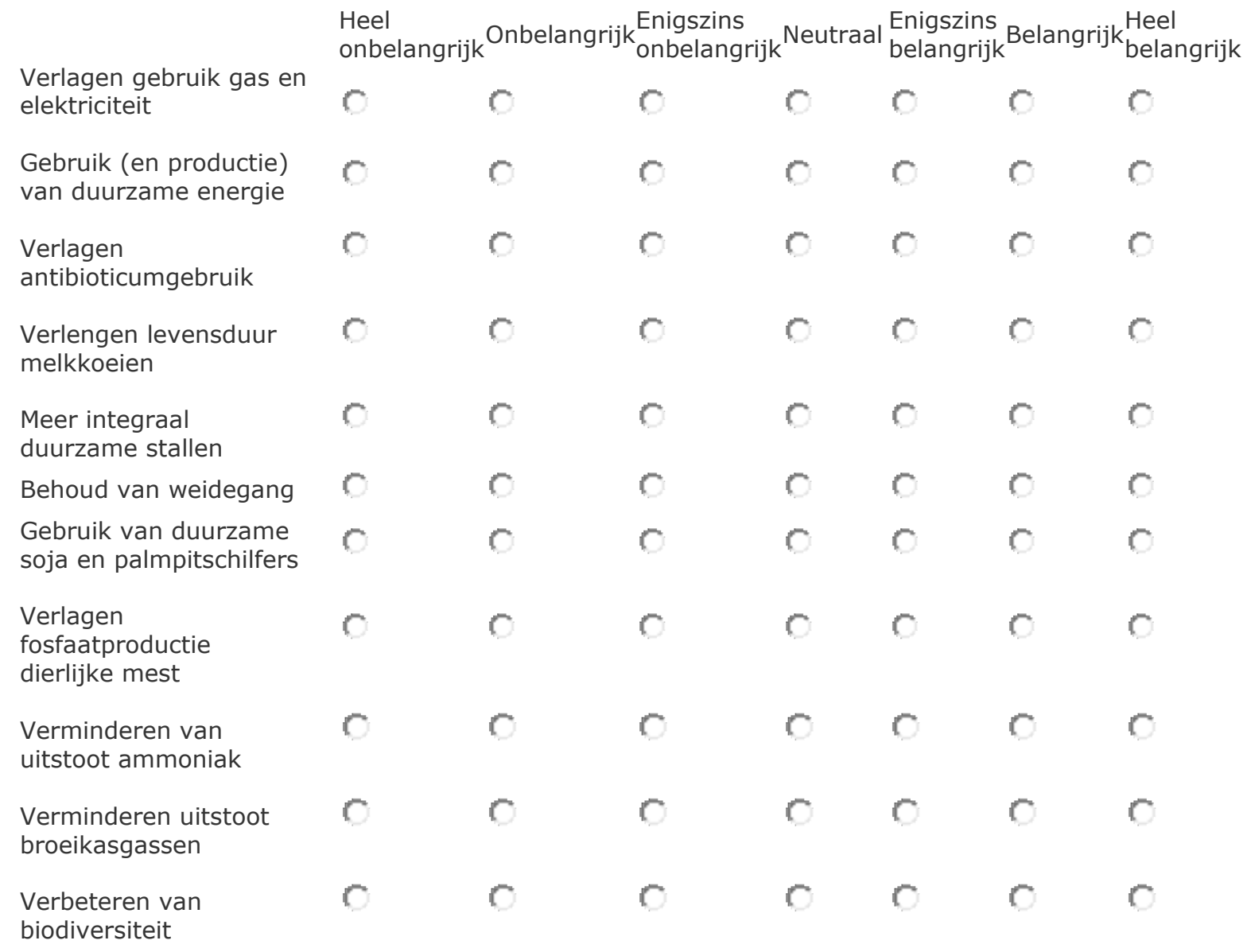




\section{Maatregel minder jongvee}

7. Bent u minder jongvee gaan houden t.o.v. 2016 (aantal stuks per 10 melkkoeien)?
a. Nee
b. Ja, sinds 2017
c. Ja, sinds 2018

8. Indien Nee: Ik ben niet minder jongvee aan gaan houden sinds 2016, omdat: (kies de belangrijkste reden)
a. Ik al weinig jongvee aan houd.
b. Ik de jongvee opfok heb uitbesteed.
c. Ik jongvee opfok voor verkoop.
d. Ik ruwvoer over heb op mijn bedrijf.
e. Anders, namelijk .....

8. Indien Ja: Ik ben minder jongvee aan gaan houden sinds 2016, omdat: (kies de belangrijkste reden)
a. Ik de fosfaatproductie in de mest op mijn bedrijf wil verminderen.
b. Ik een langere levensduur van het vee nastreef.
c. Ik krap in ruwvoer zit c.q. te weinig ruwvoer heb.
d. Ik de jongvee opfok ben gaan uitbesteden.
e. Anders, namelijk .....

8. Indien Ja: Blijft u de komende jaren hetzelfde aantal stuks jongvee per 10 melkkoeien aanhouden?
a. Ja
b. Weet niet
c. Nee, omdat .....

\section{Maatregel mest uitrijden bij gunstig weer}

9. Bent u mest gaan uitrijden onder gunstige weersomstandigheden t.o.v. 2016?
a. Nee
b. Ja, sinds 2017
c. Ja, sinds 2018

10. Indien Nee: Mest uitrijden onder geschikte weersomstandigheden lukt (vaak) niet, omdat: (kies de belangrijkste reden)
a. Ik onvoldoende mestopslagcapaciteit heb.
b. De loonwerker niet altijd op een geschikte moment beschikbaar is.
c. De weersomstandigheden te wisselvallig zijn.
d. Ik direct na het maaien bemest.
e. Anders, namelijk .....

10. Indien Ja: Mest uitrijden onder geschikte weersomstandigheden lukt (vrij) goed, omdat: (kies de belangrijkste reden)
a. Ik flexibel ben met eigen bemestingsapparatuur.
b. Ik wacht op goede weersomstandigheden.
c. De loonwerker over voldoende capaciteit beschikt om in te kunnen spelen op het weer.
d. Anders, namelijk .....

10. Indien Ja: Blijft u de komende jaren mest uitrijden onder gunstige weersomstandigheden?
a. Ja
b. Weet niet
c. Nee, omdat ..... 
11. Wint u gras met een lager ruw eiwit t.o.v. 2016?
a. Nee
b. Ja, sinds 2017
c. Ja, sinds 2018

12. Indien Nee: Ik win geen gras met een lager ruw eiwit, omdat: (kies de belangrijkste reden)
a. Ik zoveel mogelijk ruw eiwit van eigen land wil halen.
b. Ik verwacht dat het ten koste gaat van de grasopbrengst.
c. Door de hoge stikstofmineralisatie op mijn grond dat niet lukt.
d. Ik liever het rantsoen stuur via aangekocht voer.
e. Anders, namelijk .....

12. Indien Ja: Ik win gras met een lager ruw eiwit, omdat: (kies de belangrijkste reden)
a. Ik minder eiwit en meer structuur wil voeren.
b. Ik minder kunstmest ben gaan strooien.
c. Ik wat later ben gaan maaien.
d. Anders, namelijk .....

12. Indien Ja: Blijft u de komende jaren proberen om lager ruw eiwit in het gras te winnen?
a. Ja
b. Weet niet
c. Nee, omdat .....

\section{Maatregel minder eiwit rantsoen}

13. Bent u een rantsoen met een lager eiwit gehalte gaan voeren t.o.v. 2016 ?
a. Nee
b. Ja, sinds 2017
c. Ja, sinds 2018

14. Indien Nee: Ik ben geen rantsoen met een lager eiwit gehalte gaan voeren, omdat: (kies de belangrijkste reden)
a. Ik verwacht dan een lagere melkproductie per koe.
b. Ik verwacht dan een slechtere gezondheid.
c. Mijn voeradviseur dat afraadt.
d. Anders, namelijk .....

14. Indien Ja: Ik ben een rantsoen met een lager eiwit gehalte gaan voeren, omdat: (kies de belangrijkste reden)
a. Ik meer mais in het rantsoen ben gaan voeren.
b. Ik meer eiwitarmere voerproducten ben gaan aankopen.
c. Ik gras met een lager ruw eiwit gehalte ben gaan oogsten.
d. Anders, namelijk .....

14. Indien Ja: Blijft u de komende jaren lager ruw eiwit in brok voeren?
a. Ja
b. Weet niet
c. Nee, omdat ..... 
15. Bent u meer gaan beweiden t.o.v. 2016?
a. Nee
b. Ja, sinds 2017
c. Ja, sinds 2018

16. Indien Nee: Ik ben niet meer gaan beweiden, omdat: (kies de belangrijkste reden)
a. Mijn huiskavel te klein is.
b. Ik mijn koeien jaarrond op stal wil houden.
c. Ik al maximaal probeer te weiden.
d. Anders, namelijk .....

16. Indien Ja: Ik ben meer gaan beweiden, omdat: (kies de belangrijkste reden)
a. Ik veel melk uit vers gras wil produceren.
b. Ik een lage kostprijs wil realiseren.
c. Ik een lagere ammoniakemissie wil realiseren.
d. Anders, namelijk .....

16. Indien Ja: Blijft u de komende jaren meer beweiden?
a. Ja
b. Weet niet
c. Nee, omdat .....

\section{Maatregel mest verdunnen}

17. Bent u de mest gaan verdunnen met water tijdens het uitrijden of in de mestput t.o.v. 2016?
a. Nee
b. Ja, sinds 2017
c. Ja, sinds 2018

18. Indien Nee: Ik ben mest niet gaan verdunnen, omdat: (kies de belangrijkste reden)
a. De mest al voldoende dun is.
b. Uitrijden dan meer tijd en geld kost.
c. Ik de bemestingsapparatuur daar niet voor heb.
d. Anders, namelijk .....

18. Indien Ja: Ik ben mest gaan verdunnen, omdat: (kies de belangrijkste reden)
a. Het minder geuroverlast geeft.
b. Het een betere benutting van mineralen geeft.
c. Het schoner gras na bemesting geeft.
d. Het minder stikstofverliezen geeft door minder ammoniakemissie.
e. Anders, namelijk .....

18. Blijft u de komende jaren mest verdunnen?
a. Ja
b. Weet niet
c. Nee, omdat ..... 


\section{Invloedsfactoren - instanties}

19. In hoeverre zijn de volgende instanties van belang voor u geweest om ammoniak reducerende maatregelen te nemen?

$\begin{aligned} & \text { Regelgeving landelijke } \\ & \text { overheid (nu en } \\ & \text { toekomst }\end{aligned}$
$\begin{aligned} & \text { Regels vanuit de } \\ & \text { melkfabriek (nu en } \\ & \text { toekomst) }\end{aligned}$

\section{Invloedsfactoren - personen}

20. In hoeverre zijn de volgende personen van belang voor u geweest om ammoniak reducerende maatregelen te nemen?

\begin{tabular}{|c|c|c|c|c|c|c|c|}
\hline & $\begin{array}{l}\text { Heel } \\
\text { weinig }\end{array}$ & Weinig & $\begin{array}{l}\text { Enigszins } \\
\text { weinig }\end{array}$ & Gemiddelc & $\begin{array}{l}\text { Enigszins } \\
\text { veel }\end{array}$ & Veel & \\
\hline $\begin{array}{l}\text { Mijn partner en/of } \\
\text { kinderen }\end{array}$ & 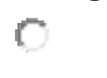 & $C$ & 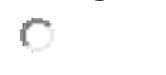 & $C$ & $c$ & $C$ & $C$ \\
\hline $\begin{array}{l}\text { Mijn adviseur van } \\
\text { voerfabriek }\end{array}$ & $C$ & $C$ & $C$ & $C$ & $C$ & $C$ & $C$ \\
\hline Mijn onafhankelijke & $C$ & $C$ & $r$ & $C$ & $C$ & $C$ & $\mathrm{C}$ \\
\hline $\begin{array}{l}\text { Een collega } \\
\text { melkveehouder }\end{array}$ & $C$ & $C$ & $C$ & $C$ & $C$ & $C$ & $C$ \\
\hline Advies van de accountant & C & $C$ & $\mathrm{C}$ & $C$ & $C$ & $C$ & C \\
\hline $\begin{array}{l}\text { Begeleider van Proeftuin } \\
\text { Veenweiden }\end{array}$ & $C$ & $C$ & $C$ & $C$ & $C$ & $C$ & $C$ \\
\hline Loonwerker & $C$ & $C$ & $\mathrm{C}$ & $r$ & 0 & $\mathrm{C}$ & $\mathrm{C}$ \\
\hline
\end{tabular}

\section{Invloedsfactoren - kennisbijeenkomsten}

21. In hoeverre zijn de volgende kennisbijeenkomsten van belang voor u geweest om ammoniak reducerende maatregelen te nemen?

Masterclasses van

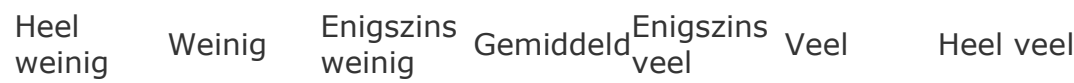

Proeftuin Veenweiden (alleen vraag voor pilotboeren)

Groepsbijeenkomst met boeren uit de Proeftuin

Studiegroep buiten de proeftuin

Open dag bij een boer Demo- of themadag van Proeftuin Veenweiden

\begin{tabular}{|c|c|c|c|c|c|c|}
\hline$C$ & 0 & $C$ & $C$ & $C$ & $\mathrm{C}$ & $C$ \\
\hline$C$ & 0 & 0 & 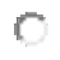 & $\sigma$ & 0 & $r$ \\
\hline$C$ & 0 & $C$ & 0 & $\sigma$ & 0 & $c$ \\
\hline$C$ & 0 & 0 & 0 & 0 & 0 & 0 \\
\hline 0 & $C$ & 0 & $C$ & $C$ & $C$ & 0 \\
\hline
\end{tabular}




\begin{tabular}{|c|c|c|c|c|c|c|c|}
\hline & $\begin{array}{l}\text { Heel } \\
\text { weinig }\end{array}$ & Weinig & $\begin{array}{l}\text { Enigszins } \\
\text { weinig }\end{array}$ & Gemiddelc & $\begin{array}{l}\text { Enigszins } \\
\text { veel }\end{array}$ & Veel & Heel veel \\
\hline nformatiedag elders & 0 & $C$ & $r$ & $c$ & 0 & $C$ & $C$ \\
\hline
\end{tabular}

\section{Invloedsfactoren - kennisbronnen}

22. In hoeverre zijn de volgende kennisbronnen van belang voor u geweest om ammoniak reducerende maatregelen te nemen?

\begin{tabular}{|c|c|c|c|c|c|c|c|}
\hline & $\begin{array}{l}\text { Heel } \\
\text { weinig }\end{array}$ & Weinig & $\begin{array}{l}\text { Enigszins } \\
\text { weinig }\end{array}$ & Gemiddelc & $\begin{array}{l}\text { Enigszins } \\
\text { veel }\end{array}$ & Veel & \\
\hline $\begin{array}{l}\text { Nieuwsbrief van } \\
\text { proeftuinveenweiden }\end{array}$ & 0 & $\mathrm{C}$ & 0 & $c$ & $\mathrm{c}$ & $\mathrm{C}$ & $C$ \\
\hline Bericht op sociale media & $C$ & $C$ & $C$ & $\mathrm{C}$ & $C$ & $C$ & $C$ \\
\hline Artikel in een vakblad & 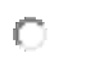 & $c$ & $c$ & 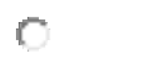 & $C$ & $c$ & $C$ \\
\hline $\begin{array}{l}\text { De uitslag van de } \\
\text { KringloopWijzer }\end{array}$ & $C$ & $C$ & 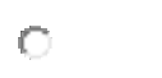 & $\mathrm{C}$ & $C$ & $C$ & $C$ \\
\hline $\begin{array}{l}\text { Onafhankelijke } \\
\text { onderzoekresultaten }\end{array}$ & $C$ & $\mathrm{C}$ & $C$ & $C$ & $C$ & $c$ & $c$ \\
\hline
\end{tabular}

\section{Invloedsfactoren - eigen inzicht en ervaring}

23. In hoeverre zijn de volgende eigen inzichten/ervaringen van belang voor u geweest om ammoniak reducerende maatregelen te nemen?

\begin{tabular}{|c|c|c|c|c|c|c|c|}
\hline & $\begin{array}{l}\text { Heel } \\
\text { weinig }\end{array}$ & Weinig & $\begin{array}{l}\text { Enigszins } \\
\text { weinig }\end{array}$ & Gemiddelc & $\begin{array}{l}\text { dEnigszins } \\
\text { veel }\end{array}$ & Veel & Heel \\
\hline $\begin{array}{l}\text { Inzet van graslandtools } \\
\text { (zoals graslandkalender) }\end{array}$ & 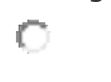 & $C$ & 0 & 0 & 0 & $C$ & $r$ \\
\hline Eigen berekeningen & $C$ & $C$ & $C$ & $\mathrm{C}$ & $C$ & $C$ & $C$ \\
\hline $\begin{array}{l}\text { Berekend economisch } \\
\text { voordeel }\end{array}$ & $\mathrm{C}$ & $C$ & $C$ & $C$ & $C$ & $C$ & $C$ \\
\hline $\begin{array}{l}\text { Eigen waarnemingen } \\
\text { (oog, oor, neus) }\end{array}$ & $C$ & $C$ & $C$ & $C$ & $C$ & $C$ & $C$ \\
\hline $\begin{array}{l}\text { Uitgevoerde analyses ( } \\
\text { bv voer, bodem, gras) }\end{array}$ & $C$ & $C$ & $C$ & $C$ & $C$ & $C$ & $\mathrm{C}$ \\
\hline Experiment van Proeftuin & $C$ & $C$ & $C$ & $\mathrm{C}$ & $C$ & $C$ & $C$ \\
\hline $\begin{array}{l}\text { Eigen testen op mijn } \\
\text { bedrijf }\end{array}$ & $\mathrm{C}$ & $C$ & $C$ & $C$ & $C$ & $C$ & $C$ \\
\hline
\end{tabular}

\section{Belemmeringen}

24. In hoeverre wordt $u$ door de onderstaande zaken belemmerd om (nog meer) veranderingen in uw bedrijfsmanagement door te voeren om de ammoniakuitstoot te verminderen?

\begin{tabular}{|c|c|c|c|c|c|c|c|}
\hline & $\begin{array}{l}\text { Heel } \\
\text { weinig }\end{array}$ & Weinig & $\begin{array}{l}\text { Enigszins } \\
\text { weinig }\end{array}$ & Gemiddeld & $\begin{array}{l}\text { Enigszins } \\
\text { veel }\end{array}$ & Veel & Heel $v$ \\
\hline Net- en regelgeving & $\mathrm{O}$ & $C$ & $c$ & $\mathrm{C}$ & $c$ & $C$ & $C$ \\
\hline k heb te weinig kennis & $C$ & $C$ & $\mathrm{C}$ & $\mathrm{C}$ & $C$ & $C$ & $C$ \\
\hline $\begin{array}{l}\text { < heb daar de tijd niet } \\
\text { oor }\end{array}$ & $C$ & $C$ & $C$ & 0 & $C$ & $C$ & $\mathrm{C}$ \\
\hline Mijn adviseur(s) raden & $C$ & $C$ & 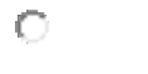 & $\mathrm{C}$ & $C$ & $C$ & $\mathrm{C}$ \\
\hline
\end{tabular}




\begin{tabular}{|c|c|c|c|c|c|c|c|}
\hline & $\begin{array}{l}\text { Heel } \\
\text { weinig }\end{array}$ & Weinig & $\begin{array}{l}\text { Enigszins } \\
\text { weinig }\end{array}$ & Gemiddelc & $d_{\text {veel }}^{\text {Enigszins }}$ & Veel & Heel v \\
\hline $\begin{array}{l}\text { De melkafnemer betaalt } \\
\text { er niet voor, dus ik vind } \\
\text { het niet nodig }\end{array}$ & $\mathrm{C}$ & $C$ & $C$ & $C$ & $c$ & $C$ & $\mathrm{C}$ \\
\hline $\begin{array}{l}\text { Ik ken geen goede } \\
\text { adviseurs die me hierin } \\
\text { kunnen ondersteunen }\end{array}$ & $\mathrm{C}$ & $C$ & $C$ & $C$ & $\mathrm{C}$ & $C$ & $\mathrm{C}$ \\
\hline $\begin{array}{l}\text { Er zijn te weinig } \\
\text { hulpmiddelen om } \\
\text { ammoniakuitstoot te } \\
\text { verminderen }\end{array}$ & $C$ & $C$ & $C$ & 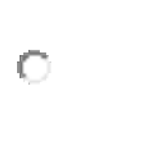 & $C$ & $C$ & $\mathrm{c}$ \\
\hline $\begin{array}{l}\text { Mijn bodemgesteldheid } \\
\text { geeft beperkingen in de } \\
\text { bedrijfsvoering }\end{array}$ & $\mathrm{C}$ & $\mathrm{C}$ & $C$ & $C$ & $\mathrm{C}$ & $C$ & $\mathrm{C}$ \\
\hline $\begin{array}{l}\text { Het weer geeft } \\
\text { beperkingen in de } \\
\text { bedrijfsvoering }\end{array}$ & $C$ & $C$ & $\mathrm{C}$ & $\mathrm{C}$ & $C$ & $\mathrm{C}$ & $\mathrm{C}$ \\
\hline Te kleine huiskavel & $C$ & $C$ & $C$ & $\mathrm{C}$ & $C$ & $C$ & $\mathrm{C}$ \\
\hline $\begin{array}{l}\text { Onderwaterdrainage is te } \\
\text { duur }\end{array}$ & $C$ & $C$ & $c$ & $C$ & $C$ & $c$ & $c$ \\
\hline $\begin{array}{l}\text { Andere dingen op mijn } \\
\text { bedrijf zijn belangrijker }\end{array}$ & $\mathrm{c}$ & $\mathrm{C}$ & $C$ & $c$ & $C$ & $\mathrm{C}$ & $c$ \\
\hline
\end{tabular}

\section{Kennisvergaring algemeen}

25. Wat zijn voor $u$ de drie belangrijkste kennisbronnen? (Kruis drie opties aan in totaal)

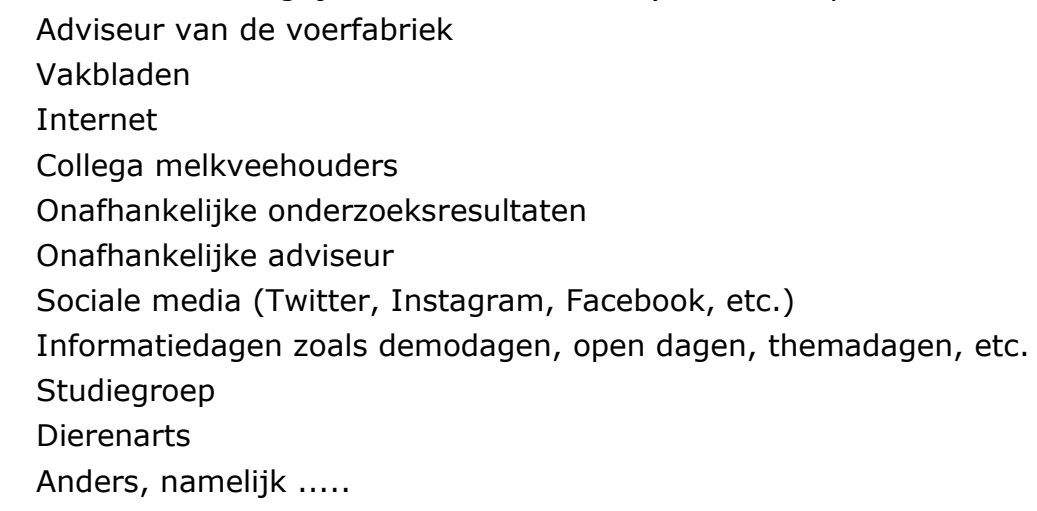

\section{Kennisvergaring uit de proeftuin}

26. Hebben de volgende communicatie activiteiten u bruikbare nieuwe kennis opgeleverd?

\begin{tabular}{|c|c|c|c|c|c|c|c|}
\hline & $\begin{array}{l}\text { Heel } \\
\text { weinig }\end{array}$ & Weinig & $\begin{array}{l}\text { Enigszins } \\
\text { weinig }\end{array}$ & Gemiddel & $\mathrm{d}_{\text {veel }}^{\text {Enigszins }}$ & Veel & Heel ve \\
\hline Pilotboer: Masterclassen & $C$ & $C$ & $c$ & 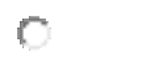 & $\mathrm{C}$ & $C$ & $C$ \\
\hline $\begin{array}{l}\text { Pilotboer: Whatsapp- } \\
\text { groep }\end{array}$ & $C$ & $C$ & $C$ & $C$ & $C$ & $C$ & $C$ \\
\hline Pilotboer: Experimenten & $C$ & $C$ & $C$ & $C$ & $C$ & $C$ & 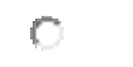 \\
\hline Studiegroepbijeenkomsten & $C$ & $C$ & $C$ & $C$ & $C$ & $C$ & $C$ \\
\hline $\begin{array}{l}\text { Themasessies voor } \\
\text { melkveehouders, } \\
\text { bedrijfsadviseurs, } \\
\text { stakeholders, } \\
\text { onderzoekers en } \\
\text { beleidsmakers }\end{array}$ & $C$ & $C$ & $C$ & $C$ & $C$ & $C$ & $C$ \\
\hline
\end{tabular}




\begin{tabular}{|c|c|c|c|c|c|c|c|}
\hline & $\begin{array}{l}\text { Heel } \\
\text { weinig }\end{array}$ & Weinig & $\begin{array}{l}\text { Enigszins } \\
\text { weinig }\end{array}$ & Gemiddeld & $\begin{array}{l}\text { Enigszins } \\
\text { veel }\end{array}$ & Veel & Heel ve \\
\hline $\begin{array}{l}\text { Nieuwsberichten via de } \\
\text { pers }\end{array}$ & $C$ & $C$ & $C$ & $C$ & $C$ & $C$ & $C$ \\
\hline Digitale nieuwsbrief & $C$ & $C$ & $C$ & $C$ & $C$ & $C$ & $C$ \\
\hline $\begin{array}{l}\text { Campagne Op Grond Van } \\
\text { Morgen }\end{array}$ & $C$ & $\mathrm{C}$ & $C$ & $\mathrm{C}$ & $\mathrm{C}$ & $\mathrm{C}$ & $C$ \\
\hline
\end{tabular}

27. Graag toelichten welke bruikbare kennis het u heeft opgeleverd of waarom het niet bruikbaar was?

\section{Mindset ondernemer}

28. Hoe belangrijk zijn deze uitspraken voor U?

Ik zoek graag de grenzen op qua voeding

Ik zoek graag de grenzen op qua

bemesting

Ik streef naar een hoge melkproductie per koe

Ik streef naar veel melk uit vers gras

Ik streef naar een hoge levensduur per koe

Ik streef naar een hoge minerale efficiëntie van het vee

Ik streef naar een hoge minerale efficiëntie van de bodem

Ik streef naar een hoge minerale efficiëntie van het bedrijf

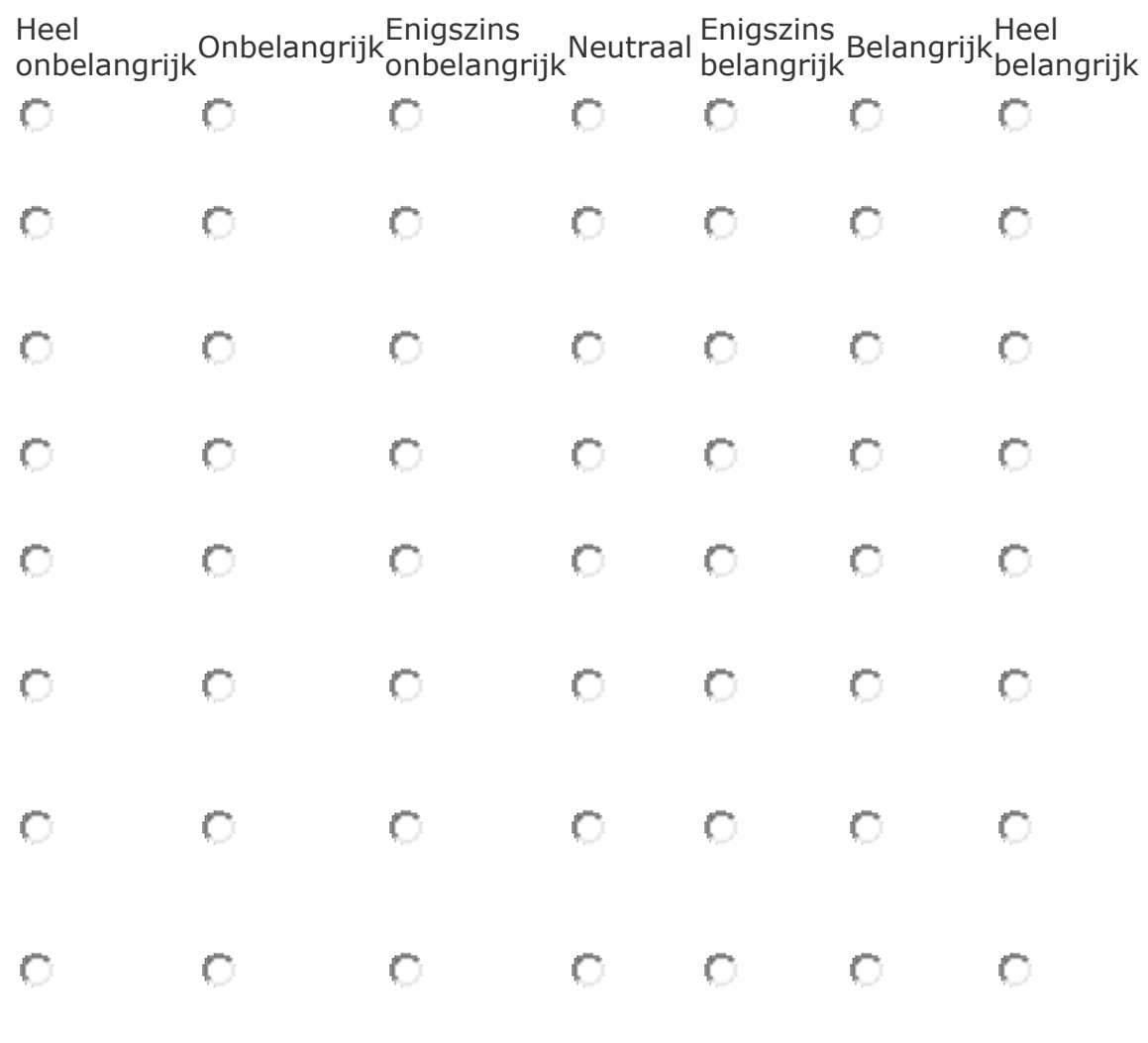

\section{Project Proeftuin Veenweiden}

29. De laatste vraag over het verloop van het Project Proeftuin Veenweiden

- Waar bent u tevreden over?

- Waar bent u ontevreden over?

- Tips voor het project? 


\section{Bijlage 3 Vragenlijst interviews begeleiders, adviseurs en loonwerker}

De volgende opzet is gehanteerd bij de interviews:

1) Toelichting rol in project Veenweiden en buiten project Veenweiden (wat is uw functie?)?

2) Hoe belangrijk is verminderen ammoniakemissie voor (schaal 1-7)
a) $U$
b) Pilotboeren
c) Volgerboeren

3) Wat zijn volgens u typische kenmerken van de pilot- en volgerboeren?
a) Pilotboeren
b) Volgerboeren

4) Uw netwerk

a) Welke kennisbronnen zijn voor u zelf belangrijk?

b) Op welke wijze laat $u$ kennis doorstromen naar melkveehouders (in het algemeen)? Licht de belangrijkste toe

5) Tijdlijn (op flap)

a) Aan welke communicatieactiviteiten in Proeftuin Veenweiden hebt u bijgedragen? Denk aan:

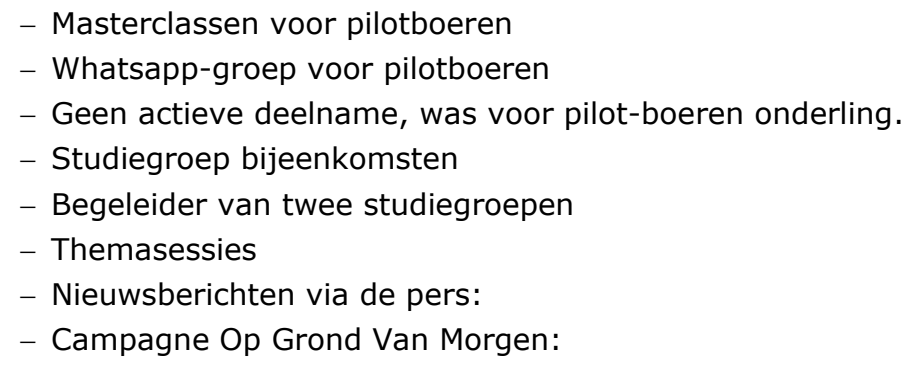

b) Wat waren voor $u$ belangrijke leermomenten?

c) Welke communicatie activiteiten hebben volgens u veel impact gehad? (die zorgden voor gedragsverandering bij boeren; licht toe)

6) Hoe belangrijk zijn volgens u de volgende maatregelen voor pilotboeren en volgerboeren?
(op schaal 1-7)
a) Minder jongvee
b) Mest aanwenden onder gunstige weersomstandigheden
c) Mest verdunnen (in stal of op erf)
d) Minder eiwit in gras (door minder bemesten en / of later maaien)
e) Meer mais bijvoeren
f) Minder eiwit in brok
g) Meer weiden
h) Andere kunstmest gebruiken
i) Emissiearme vloeren in stal

7) Wat zijn redenen om de maatregel (zie $6 \mathrm{at} / \mathrm{m} 6 \mathrm{i}$ ) wel of niet toe te passen? 
8) Wie of wat heeft een sterke invloed op die beslissing?

Denk aan:
a) Instanties (regelgeving en beleid overheden, zuivel)
b) Personen (familie, adviseurs, collega's,...)
c) Kennisbijeenkomsten (binnen of buiten de Proeftuin)
d) Kennisbronnen: nieuwsbrieven, sociale media, artikelen, onderzoek, KLW,...)
e) Verwachtingen op basis van eigen inzicht en ervaring
f) (tools, economie, eigen waarnemingen, analyses, testen, experimenten)

9) Waardoor worden melkveehouders belemmerd om veranderingen in hun bedrijfsmanagement door te voeren om de ammoniakuitstoot te verminderen? (Licht toe)

Denk aan:

1. Wet- en regelgeving

2. Krijgt geen prioriteit

3. Krijgen er geen vergoeding voor

4. Hebben te weinig kennis

5. Er zijn te weinig hulpmiddelen

6. De bodemgesteldheid geeft teveel beperkingen

7. Het weer geeft teveel beperkingen

8. Maatregelen zijn te duur

10) Welke aanpak werkt volgens $u$ het beste om de melkveehouderij minder ammoniak te laten uitstoten? (RESET)

a) Indien mogelijk kunt u daarbij onderscheid maken tussen typen bedrijven, typen vakman, typen ondernemer of leerstijlen?

b) Is dat voor reduceren ammoniak anders dan voor andere duurzaamheidsdoelen, zoals meer beweiden, verlengen levensduur vee, verminderen antibioticagebruik, etc.?

11) Hebt u nog tips, vragen of opmerkingen over gedragsveranderingen van melkveehouders in het veenweidegebied? 


\section{Bijlage 4 Toepassing van ammoniak reducerende maatregelen}

\section{Toepassing van de maatregel minder jongvee}

Bent u minder jongvee gaan houden t.o.v. 2016 (aantal stuks per 10 melkkoeien)?

- Nee

$26,3 \%(15)$

- Ja, sinds $2017 \quad 54,4 \%(31)$

- Ja, sinds $2018 \quad 19,3 \%(11)$

Ik ben niet minder jongvee aan gaan houden sinds 2016, omdat:

- Ik al weinig jongvee aan houd.

$53,3 \%(8)$

- Ik de jongvee opfok heb uitbesteed. $6,7 \% \quad$ (1)

- Ik jongvee opfok voor verkoop. $0,0 \% \quad(0)$

- Ik ruwvoer over heb op mijn bedrijf. $26,7 \% \quad(4)$

- Anders, namelijk:

$13,3 \% \quad(2)$

- wil weer uitbreiden.

- $\quad$ ik al 10 jaar geen jongvee meer heb.

Ik ben minder jongvee aan gaan houden sinds 2016, omdat:

- Ik de fosfaatproductie in de mest op mijn bedrijf wil verminderen. $35,7 \%$ (15)

- Ik een langere levensduur van het vee nastreef.

$35,7 \% \quad(15)$

- Ik krap in ruwvoer zit c.q. te weinig ruwvoer heb.

$4,8 \% \quad(2)$

- Ik de jongvee opfok ben gaan uitbesteden.

$0,0 \% \quad(0)$

- Anders, namelijk:

- het aantal melkkoeien zoveel mogelijk te kunnen blijven houden en zat ruim in het jongvee.

- $\quad \mathrm{ik}$ had teveel jongvee en wil niet meer groeien.

- fosfaatrechten.

- meer melkkoeien gaan houden en i.v.m. fosfaat minder jongvee gaan houden.

- bijna alle koeien met blauwe stier gedekt.

- door fosfaatreductie veel oudere koeien opgeruimd. leeftijd veestapel behoorlijk gedaald, door minder vervanging heb ik minder jongvee aangehouden.

- fosfaat rechten.

- meer stieren geboren werden.

- hier door meer koeien kan melken.

- max wil melken binnen de fosfaatruimte.

Blijft u de komende jaren hetzelfde aantal stuks jongvee per 10 melkkoeien aanhouden?

- Ja $54,8 \% \quad$ (23)

- Weet niet

$$
23,8 \% \text { (10) }
$$

- Nee, omdat:

$$
21,4 \% \quad \text { (9) }
$$

- is wel afhankelijk of ik voldoende eigen aanwas heb, wil geen jongvee van buitenaf.

- $\quad$ zit nu extreem laag 3 stuks op 10 koeien. groei wordt zo erg lastig.

- $\quad$ het nog iets lager kan.

- we aan het inkruisen zijn met fleckvieh. Ik verwacht sterkere koeien en hopelijk minder uitval.

- levensduur verlengen.

- er meer nodig heb.

- groeiplannen doodgemaakt zijn en aankoop vaarzen hiermee gestimuleerd worden, de doodsteek voor een gesloten bedrijfsvoering.

- nog minder jongvee (6/10).

- denk nu iets te scherp. dat ga je over een paar jaar merken. 


\section{Toepassing van de maatregel mest uitrijden bij gunstig weer}

Bent u mest gaan uitrijden onder gunstige weersomstandigheden t.o.v. 2016?
- Nee
$40,3 \%$
(23)
- Ja, sinds 2017
$57,9 \%(33)$
- Ja, sinds 2018
$1,8 \%$

Mest uitrijden onder geschikte weersomstandigheden lukt (vaak) niet, omdat:

- Ik onvoldoende mestopslagcapaciteit heb.

- De loonwerker niet altijd op een geschikte moment beschikbaar is.

- De weersomstandigheden te wisselvallig zijn.

- Ik direct na het maaien bemest.

- Anders, namelijk:

- probeer onder ideale omstandigheden mest uit te rijden, ik heb ook rekening te houden met beweidingsplan, ik wil in het najaar liever weinig/geen mest meer uitrijden, en lastig seizoen 2017 om het goed te doen.

- meestal wel heb ook voldoende opslagruimte.

- ik ben hier al voor 2016 mee bezig.

- in 2016 ook probeerde zo gunstig mogelijk uit te rijden.

- ik al langer onder geschikte omstandigheden mest uitrijd.

- ik hou altijd rekening met het weer en de tijd, ook al voor 2017.

- weer en arbeid/benodigde tijd.

- ik rij al voor 2017 mest onder gunstige omstandigheden uit met eigen bemestingsapparatuur.

- al voor 2017 mest uitrijden onder gunstige omstandigheden met eigen bemestingsapparatuur.

Mest uitrijden onder geschikte weersomstandigheden lukt (vrij) goed, omdat:

- Ik flexibel ben met eigen bemestingsapparatuur.

- Ik wacht op goede weersomstandigheden.

- De loonwerker over voldoende capaciteit beschikt om in te kunnen

- Ik de jongvee opfok ben gaan uitbesteden.

Blijft $\mathrm{u}$ de komende jaren mest uitrijden onder gunstige weersomstandigheden?

- Ja

- Weet niet

- Nee, omdat:
$76,5 \% \quad(26)$

$17,6 \% \quad(6)$

$5,9 \% \quad(2)$

- de loonwerker moet het doen.

- ik streef er wel naar, maar het blijft afhankelijk van de loonwerker.

\section{Toepassing van de maatregel minder eiwit in het gras}

Wint u gras met een lager ruw eiwit t.o.v. 2016?
- Nee
$54,4 \%(31)$
- Ja, sinds 2017
$28,1 \%(16)$
- Ja, sinds 2018

$$
17,5 \%(10)
$$

Ik win geen gras met een lager ruw eiwit, omdat:

- Ik zoveel mogelijk ruw eiwit van eigen land wil halen.
$41,9 \% \quad(13)$
$3,2 \% \quad(1)$
$29,0 \% \quad(9)$

- Door de hoge stikstofmineralisatie op mijn grond dat niet lukt.

- Ik liever het rantsoen stuur via aangekocht voer.

- Anders, namelijk:

- ik zoveel mogelijk ruw eiwit van eigenland wil halen, maar ook structuurrijker gras met laag ruw eiwit.

- 2016 zat er weinig in, lager is niet wenselijk. 
- $\quad$ ik eerst andere prioriteiten stel.

- was al laag 2016.

- het weer niet in de hand.

- mijn ruw eiwit totaal is ieder jaar 40 lager dan de streefwaarde.

Ik win gras met een lager ruw eiwit, omdat:

- Ik minder eiwit en meer structuur wil voeren.

- Ik minder kunstmest ben gaan strooien.

- Ik wat later ben gaan maaien.

- Anders, namelijk:

- omschakeling naar biologisch.

- ruw eiwit is niet het belangrijkste DVE moet omhoog.

- ik geen kas meer strooi.

- biologisch.

Blijft u de komende jaren proberen om lager ruw eiwit in het gras te winnen?
- Ja $61,5 \% \quad(16)$
- Weet niet
$30,8 \%$
- $\quad$ Nee, omdat: $7,7 \%$

- $\quad$ ruw eiwit in de zomer is niet te sturen, bij de eerste en tweede snee redelijk grof gras droog inkuilen dan gaat de DVE omhoog. Dit gelijktijdig met de latere sneden voeren.

- $\quad$ het nu te laag is.

Toepassing van de maatregel minder eiwit in het rantsoen

Bent u een rantsoen met een lager eiwit gehalte gaan voeren t.o.v. 2016?

- $\quad$ Nee

- Ja, sinds 2017

- Ja, sinds 2018

$$
\begin{aligned}
& 29,8 \%(17) \\
& 56,1 \%(32) \\
& 14,1 \%(8)
\end{aligned}
$$

Ik ben geen rantsoen met een lager eiwit gehalte gaan voeren, omdat:

- Ik verwacht dan een lagere melkproductie per koe. $\quad 58,8 \%$

- Ik verwacht dan een slechtere gezondheid. $\quad 0,0 \% \quad(0)$

- Mijn voeradviseur dat afraadt. $\quad 5,9 \%$ (1)

- Anders, namelijk:

- probeer al jaren de grens op te zoeken.

- het steven is om het ureum onder de 20 te houden dus zo efficiënt mogelijk voeren.

- was al laag, dus daarom niet perse lager, voer ook redelijk kilo's mais.

- we nemen een brok waarbij je dan in het rantsoen minder ruw eiwit hebt.

- mijn eiwit is altijd heel laag in het rantsoen geweest.

- voer al op de norm.

Ik ben een rantsoen met een lager eiwit gehalte gaan voeren, omdat:

- Ik meer mais in het rantsoen ben gaan voeren.

$12,5 \% \quad(5)$

$45,0 \% \quad(18)$

- Ik meer eiwitarmere voerproducten ben gaan aankopen.

$35,0 \% \quad(14)$

- Ik gras met een lage

$7,5 \%$

- lager ruw eiwit in de brok.

- $\quad$ eiwit rijk gras mengen met hooi of eiwitarm kuilgras.

- $\quad$ krachtvoer eiwit lager en gras eiwit lager.

Blijft u de komende jaren lager ruw eiwit in brok voeren?

- Ja 65,0\% (26)

- Weet niet $27,5 \%$ (11)

- $\quad$ Nee, omdat: $7,5 \%$ (3)

- ons gras al een veel lager ruw eiwit heeft.

- eiwit gehalte is laag en daarmee goed.

- $\quad$ een aanvulling in DVE nodig is wegens de efficiënte eiwit omzetting. 


\section{Toepassing van de maatregel meer beweiden}

Bent u meer gaan beweiden t.o.v. 2016?

- $\quad$ Nee

- Ja, sinds 2017

- Ja, sinds 2018

$5,3 \%$

Ik ben niet meer gaan beweiden, omdat:

- Mijn huiskavel te klein is.

$11,4 \% \quad(5)$

$6,8 \% \quad(3)$

$61,4 \% \quad(27)$

- Ik al maximaal probeer te weiden.

$20,4 \% \quad(9)$

- Anders, namelijk:

- ben robot gaan melken.

- $\quad$ net hoe het seizoen en voervoorraad loopt.

- de koeien niet 's nachts wil gaan weiden.

- $\quad$ het bedrijfssysteem op $120 \times 6$ is gemaakt.

- niet maximaal, maar optimaal voor hoeveelheid koeien t.o.v. huiskavel.

- $\max 6$ uur door robotmelken.

- ook gras op stal voeren.

- robot plus droogte.

- Voor 2017 al omdat ik veel melk uit vers gras wil produceren.

Ik ben meer gaan beweiden, omdat:

- Ik veel melk uit vers gras wil produceren. $\quad 30,8 \%$ (4)

- Ik een lage kostprijs wil realiseren. $38,5 \%$ (5)

- Ik een lagere ammoniakemissie wil realiseren. $0,0 \% \quad(0)$

- Anders, namelijk:

- minder koeien heb.

- de consument het wil.

- jongvee wil leren.

- meer grond.

Blijft u de komende jaren meer beweiden?

- Ja 76,9\% (10)

- Weet niet $23.1 \%(3)$

- Nee, omdat: $0,0 \% \quad(0)$

\section{Toepassing van de maatregel mest verdunnen}

Bent $\mathrm{u}$ de mest gaan verdunnen met water tijdens het uitrijden of in de mestput t.o.v. 2016?

- Nee $29,8 \% \quad(17)$

- Ja, sinds 2017 $61,4 \% \quad(35)$

- Ja, sinds 2018 $8,8 \%$

Ik ben mest niet gaan verdunnen, omdat:

- De mest al voldoende dun is.

- Uitrijden dan meer tijd en geld kost.

- Ik de bemestingsapparatuur daar niet voor heb. $\quad 5,9 \%$

- Anders, namelijk:

- al voor 2016 de grootste oppervlakte verdund uitrij.

- doe het al jaren verdunnen.

- doe dat al jaren.

- altijd al doe.

- wij verdunden de mest altijd al.

- verdunnen en/of inregenen doen we al jaren.

- deed het hiervoor ook al met sleepslang.

- doe ik al jaren.

- ik verdunde al jaren.

- ik altijd al mest verdund heb. 
- doe ik al heel lang.

- $\quad$ ik met de tank uitrij en een deel drassig land op afstand heb.

- $\quad$ ik doe dit al langer dan 2016.

- voor 2017 al begonnen vanwege betere benutting mineralen.

- ja voor 2017 om het minder stikstofverliezen geeft door minder ammoniakemissie.

Ik ben mest gaan verdunnen, omdat: (kies de belangrijkste reden)

- Het minder geuroverlast geeft.

$0,0 \% \quad(0)$

- Het een betere benutting van mineralen geeft.

$50,0 \% \quad(20)$

- Het schoner gras na bemesting geeft.

$0,0 \% \quad(0)$

- Het minder stikstofverliezen geeft door minder ammoniakemissie.

$45,0 \% \quad(18)$

- Anders, namelijk:

$5,0 \% \quad(2)$

- alle vier de redenen.

- nodig is bij slang bemesten.

Blijft u de komende jaren mest verdunnen?

- Ja 100,0\%(40)

- Weet niet $0,0 \% \quad(0)$

- Nee, omdat $0,0 \% \quad(0)$ 


\section{Bijlage 5 Invloedsfactoren}

\section{$\underline{\text { Instanties }}$}

Tabel A Perceptie van de geënquêteerde melkveehouders in welke mate instanties van belang voor hen zijn geweest om ammoniak reducerende maatregelen te nemen.

\begin{tabular}{|c|c|c|c|c|c|c|c|}
\hline Instantie & $\begin{array}{l}\text { Heel } \\
\text { onbelangrijk }\end{array}$ & Onbelangrijk & $\begin{array}{l}\text { Enigszins } \\
\text { onbelangrijk }\end{array}$ & Neutraal & $\begin{array}{l}\text { Enigszins } \\
\text { belangrijk }\end{array}$ & Belangrijk & $\begin{array}{l}\text { Heel } \\
\text { belangrijk }\end{array}$ \\
\hline $\begin{array}{l}\text { Landelijke overheid } \\
\text { (nu en toekomst) }\end{array}$ & $\begin{array}{c}5.26 \% \\
(3)\end{array}$ & $\begin{array}{c}10.53 \% \\
(6)\end{array}$ & $\begin{array}{c}7.02 \% \\
(4)\end{array}$ & $\begin{array}{l}24.56 \% \\
(14)\end{array}$ & $\begin{array}{c}14.04 \% \\
(8)\end{array}$ & $\begin{array}{c}31.58 \% \\
(18)\end{array}$ & $\begin{array}{c}7.02 \% \\
(4)\end{array}$ \\
\hline $\begin{array}{l}\text { Regels vanuit de } \\
\text { melkfabriek (nu en } \\
\text { toekomst) }\end{array}$ & $\begin{array}{l}3.51 \% \\
(2)\end{array}$ & $\begin{array}{l}12.28 \% \\
(7)\end{array}$ & $\begin{array}{l}10.53 \% \\
(6)\end{array}$ & $\begin{array}{l}33.33 \% \\
(19)\end{array}$ & $\begin{array}{l}15.79 \% \\
(9)\end{array}$ & $\begin{array}{l}21.05 \% \\
\quad(12)\end{array}$ & $\begin{array}{l}3.51 \% \\
(2)\end{array}$ \\
\hline $\begin{array}{l}\text { Beleid van } \\
\text { gemeente } \\
\text { en provincie }\end{array}$ & $\begin{array}{l}19.30 \% \\
(11)\end{array}$ & $\begin{array}{l}26.32 \% \\
\quad(15)\end{array}$ & $\begin{array}{l}14.04 \% \\
(8)\end{array}$ & $\begin{array}{l}28.07 \% \\
(16)\end{array}$ & $\begin{array}{l}8.77 \% \\
(5)\end{array}$ & $\begin{array}{l}3.51 \% \\
(2)\end{array}$ & $\begin{array}{l}0.00 \% \\
(0)\end{array}$ \\
\hline
\end{tabular}

Volgorde van instanties t.a.v. het belang voor de geënquêteerde melkveehouders om ammoniak reducerende maatregelen te nemen:
1. Regelgeving landelijke overheid (nu en toekomst)
4.54
2. Regels vanuit de melkfabriek (nu en toekomst)
4.23
3. Regels van het waterschap
3.12
4. Beleid van gemeente en provincie
2.91

\section{Personen}

Tabel B Perceptie van de geënquêteerde melkveehouders in welke mate personen van belang voor hen zijn geweest om ammoniak reducerende maatregelen te nemen.

\begin{tabular}{|c|c|c|c|c|c|c|c|}
\hline Persoon & $\begin{array}{l}\text { Heel } \\
\text { onbelangrijk }\end{array}$ & Onbelangrijk & $\begin{array}{l}\text { Enigszins } \\
\text { onbelangrijk }\end{array}$ & Neutraal & $\begin{array}{l}\text { Enigszins } \\
\text { belangrijk }\end{array}$ & Belangrijk & $\begin{array}{l}\text { Heel } \\
\text { belangrijk }\end{array}$ \\
\hline $\begin{array}{l}\text { Mijn partner en/of } \\
\text { kinderen }\end{array}$ & $\begin{array}{c}29.82 \% \\
(17)\end{array}$ & $\begin{array}{c}17.54 \% \\
(10)\end{array}$ & $\begin{array}{c}7.02 \% \\
(4)\end{array}$ & $\begin{array}{c}28.07 \% \\
(16)\end{array}$ & $\begin{array}{c}8.77 \% \\
(5)\end{array}$ & $\begin{array}{c}7.02 \% \\
(4)\end{array}$ & $\begin{array}{c}1.75 \% \\
(1)\end{array}$ \\
\hline $\begin{array}{l}\text { Mijn adviseur van } \\
\text { voerfabriek }\end{array}$ & $\begin{array}{c}17.54 \% \\
(10)\end{array}$ & $\begin{array}{c}21.05 \% \\
(12)\end{array}$ & $\begin{array}{c}12.28 \% \\
(7)\end{array}$ & $\begin{array}{c}26.32 \% \\
(15)\end{array}$ & $\begin{array}{c}14.04 \% \\
(8)\end{array}$ & $\begin{array}{l}8.77 \% \\
(5)\end{array}$ & $\begin{array}{c}0.00 \% \\
(0)\end{array}$ \\
\hline $\begin{array}{l}\text { Mijn onafhankelijke } \\
\text { adviseur }\end{array}$ & $\begin{array}{l}21.05 \% \\
(12)\end{array}$ & $\begin{array}{c}17.54 \% \\
(10)\end{array}$ & $\begin{array}{l}5.26 \% \\
(3)\end{array}$ & $\begin{array}{c}24.56 \% \\
(14)\end{array}$ & $\begin{array}{c}17.54 \% \\
(10)\end{array}$ & $\begin{array}{c}10.53 \% \\
(6)\end{array}$ & $\begin{array}{l}3.51 \% \\
(2)\end{array}$ \\
\hline $\begin{array}{l}\text { Een collega } \\
\text { melkveehouder }\end{array}$ & $\begin{array}{l}22.81 \% \\
\quad(13)\end{array}$ & $\begin{array}{c}15.79 \% \\
(9)\end{array}$ & $\begin{array}{c}12.28 \% \\
(7)\end{array}$ & $\begin{array}{l}21.05 \% \\
(12)\end{array}$ & $\begin{array}{l}21.05 \% \\
(12)\end{array}$ & $\begin{array}{l}5.26 \% \\
(3)\end{array}$ & $\begin{array}{l}1.75 \% \\
(1)\end{array}$ \\
\hline $\begin{array}{l}\text { Advies van de } \\
\text { accountant }\end{array}$ & $\begin{array}{c}38.60 \% \\
(22)\end{array}$ & $\begin{array}{c}29.82 \% \\
(17)\end{array}$ & $\begin{array}{l}15.79 \% \\
(9)\end{array}$ & $\begin{array}{c}14.04 \% \\
(8)\end{array}$ & $\begin{array}{c}1.75 \% \\
(1)\end{array}$ & $\begin{array}{c}0.00 \% \\
(0)\end{array}$ & $\begin{array}{c}0.00 \% \\
(0)\end{array}$ \\
\hline $\begin{array}{l}\text { Begeleider van } \\
\text { Proeftuin } \\
\text { Veenweiden }\end{array}$ & $\begin{array}{c}7.02 \% \\
(4)\end{array}$ & $\begin{array}{c}1.75 \% \\
\text { (1) }\end{array}$ & $\begin{array}{c}7.02 \% \\
(4)\end{array}$ & $\begin{array}{c}19.30 \% \\
(11)\end{array}$ & $\begin{array}{c}21.05 \% \\
(12)\end{array}$ & $\begin{array}{c}31.58 \% \\
(18)\end{array}$ & $\begin{array}{c}12.28 \% \\
(7)\end{array}$ \\
\hline
\end{tabular}

Volgorde van personen t.a.v. het belang voor de geënquêteerde melkveehouders om ammoniak reducerende maatregelen te nemen:
1. Begeleider van Proeftuin Veenweiden
2. Mijn onafhankelijke adviseur
3. Mijn adviseur van voerfabriek
4. Een collega melkveehouder
5. Mijn partner en/of kinderen
6. Loonwerker
2.60
7. Advies van de accountant 
Kennisbijeenkomsten

Tabel C Perceptie van de geënquêteerde melkveehouders in welke mate kennisbijeenkomsten van belang voor hen zijn geweest om ammoniak reducerende maatregelen te nemen.

\begin{tabular}{|c|c|c|c|c|c|c|c|}
\hline Kennisbijeenkomst & $\begin{array}{l}\text { Heel } \\
\text { onbelangrijk }\end{array}$ & Onbelangrijk & $\begin{array}{l}\text { Enigszins } \\
\text { onbelangrijk }\end{array}$ & Neutraal & $\begin{array}{l}\text { Enigszins } \\
\text { belangrijk }\end{array}$ & Belangrijk & $\begin{array}{l}\text { Heel } \\
\text { belangrijk }\end{array}$ \\
\hline Masterclasses van & $0.00 \%$ & $0.00 \%$ & $0.00 \%$ & $28.57 \%$ & $14.29 \%$ & $57.14 \%$ & $0.00 \%$ \\
\hline
\end{tabular}

Proeftuin $\quad(0) \quad(0) \quad(0) \quad$ (2)

Veenweiden (alleen

voor pilotboeren)

Groepsbijeenkomst

$5.26 \%$

$5.26 \%$

$0.00 \%$

$22.81 \%$

$28.07 \%$

$28.07 \% \quad 10.53 \%$

met boeren
Proeftuin

(3) (3)

(0) (13)

(16)

(16)

(6)

\begin{tabular}{|c|c|c|c|c|c|c|c|}
\hline $\begin{array}{l}\text { Studiegroep buiten } \\
\text { de proeftuin }\end{array}$ & $\begin{array}{l}14.04 \% \\
(8)\end{array}$ & $\begin{array}{l}8.77 \% \\
(5)\end{array}$ & $\begin{array}{c}10.53 \% \\
(6)\end{array}$ & $\begin{array}{l}21.05 \% \\
(12)\end{array}$ & $\begin{array}{l}22.81 \% \\
(13)\end{array}$ & $\begin{array}{l}22.81 \% \\
(13)\end{array}$ & $\begin{array}{c}0.00 \% \\
(0)\end{array}$ \\
\hline $\begin{array}{l}\text { Open dag bij een } \\
\text { boer }\end{array}$ & $\begin{array}{l}26.32 \% \\
(15)\end{array}$ & $\begin{array}{l}29.82 \% \\
(17)\end{array}$ & $\begin{array}{c}10.53 \% \\
(6)\end{array}$ & $\begin{array}{c}19.30 \% \\
(11)\end{array}$ & $\begin{array}{c}14.04 \% \\
(8)\end{array}$ & $\begin{array}{l}0.00 \% \\
(0)\end{array}$ & $\begin{array}{c}0.00 \% \\
(0)\end{array}$ \\
\hline $\begin{array}{l}\text { Demo- of themadag } \\
\text { van Proeftuin } \\
\text { Veenweiden }\end{array}$ & $\begin{array}{l}15.79 \% \\
(9)\end{array}$ & $\begin{array}{c}14.04 \% \\
(8)\end{array}$ & $\begin{array}{l}1.75 \% \\
(1)\end{array}$ & $\begin{array}{l}35.09 \% \\
(20)\end{array}$ & $\begin{array}{l}19.30 \% \\
(11)\end{array}$ & $\begin{array}{l}8.77 \% \\
(5)\end{array}$ & $\begin{array}{c}5.26 \% \\
\text { (3) }\end{array}$ \\
\hline
\end{tabular}

Volgorde van kennisbijeenkomsten t.a.v. het belang voor de geënquêteerde melkveehouders om ammoniak reducerende maatregelen te nemen:
1. Masterclasses van Proeftuin Veenweiden
5.29
2. Groepsbijeenkomst met boeren uit de Proeftuin
4.89
3. Studiegroep buiten de proeftuin
3.98
4. Demo- of themadag van Proeftuin Veenweiden
3.75
5. Informatiedag elders
3.33
6. Open dag bij een boer
2.65

\section{Kennisbronnen}

Tabel D Perceptie van de geënquêteerde melkveehouders in welke mate kennisbronnen van belang voor hen zijn geweest om ammoniak reducerende maatregelen te nemen.

\begin{tabular}{|c|c|c|c|c|c|c|c|}
\hline Kennisbron & $\begin{array}{l}\text { Heel } \\
\text { onbelangrijk }\end{array}$ & Onbelangrijk & $\begin{array}{l}\text { Enigszins } \\
\text { onbelangrijk }\end{array}$ & Neutraal & $\begin{array}{l}\text { Enigszins } \\
\text { belangrijk }\end{array}$ & Belangrijk & $\begin{array}{l}\text { Heel } \\
\text { belangrijk }\end{array}$ \\
\hline $\begin{array}{l}\text { Nieuwsbrief van } \\
\text { proeftuinveenweiden }\end{array}$ & $\begin{array}{c}12.50 \% \\
(7)\end{array}$ & $\begin{array}{c}10.71 \% \\
(6)\end{array}$ & $\begin{array}{c}8.93 \% \\
(5)\end{array}$ & $\begin{array}{l}30.36 \% \\
(17)\end{array}$ & $\begin{array}{c}21.43 \% \\
(12)\end{array}$ & $\begin{array}{c}10.71 \% \\
(6)\end{array}$ & $\begin{array}{c}5.36 \% \\
(3)\end{array}$ \\
\hline $\begin{array}{l}\text { Bericht op sociale } \\
\text { media (o.a. twitter, } \\
\text { Facebook) }\end{array}$ & $\begin{array}{l}44.64 \% \\
\quad(25)\end{array}$ & $\begin{array}{l}19.64 \% \\
(11)\end{array}$ & $\begin{array}{l}5.36 \% \\
(3)\end{array}$ & $\begin{array}{l}19.64 \% \\
(11)\end{array}$ & $\begin{array}{l}7.14 \% \\
(4)\end{array}$ & $\begin{array}{l}3.57 \% \\
(2)\end{array}$ & $\begin{array}{l}0.00 \% \\
(0)\end{array}$ \\
\hline $\begin{array}{l}\text { De uitslag van de } \\
\text { KringloopWijzer }\end{array}$ & $\begin{array}{l}10.71 \% \\
(6)\end{array}$ & $\begin{array}{l}8.93 \% \\
(5)\end{array}$ & $\begin{array}{l}10.71 \% \\
(6)\end{array}$ & $\begin{array}{c}16.07 \% \\
(9)\end{array}$ & $\begin{array}{l}26.79 \% \\
(15)\end{array}$ & $\begin{array}{l}23.21 \% \\
\quad(13)\end{array}$ & $\begin{array}{l}3.57 \% \\
(2)\end{array}$ \\
\hline $\begin{array}{l}\text { Onafhankelijke } \\
\text { onderzoekresultaten }\end{array}$ & $\begin{array}{c}12.50 \% \\
(7)\end{array}$ & $\begin{array}{c}12.50 \% \\
(7)\end{array}$ & $\begin{array}{l}3.57 \% \\
(2)\end{array}$ & $\begin{array}{l}25.00 \% \\
(14)\end{array}$ & $\begin{array}{l}28.57 \% \\
\quad(16)\end{array}$ & $\begin{array}{c}16.07 \% \\
(9)\end{array}$ & $\begin{array}{c}1.79 \% \\
(1)\end{array}$ \\
\hline
\end{tabular}

Onderschrift (Tabelonderschrift).

Volgorde van kennisbronnen t.a.v. het belang voor de geënquêteerde melkveehouders om ammoniak reducerende maatregelen te nemen:
1. De uitslag van de KringloopWijzer
2. Artikel in een vakblad
3. Onafhankelijke onderzoekresultaten
4.00
4. Nieuwsbrief van proeftuinveenweiden
3.91
5. Bericht op sociale media (o.a. twitter, Facebook) 
Eigen inzicht en ervaring

Tabel E Perceptie van de geënquêteerde melkveehouders in welke mate eigen inzicht en ervaring van belang voor hen zijn geweest om ammoniak reducerende maatregelen te nemen.

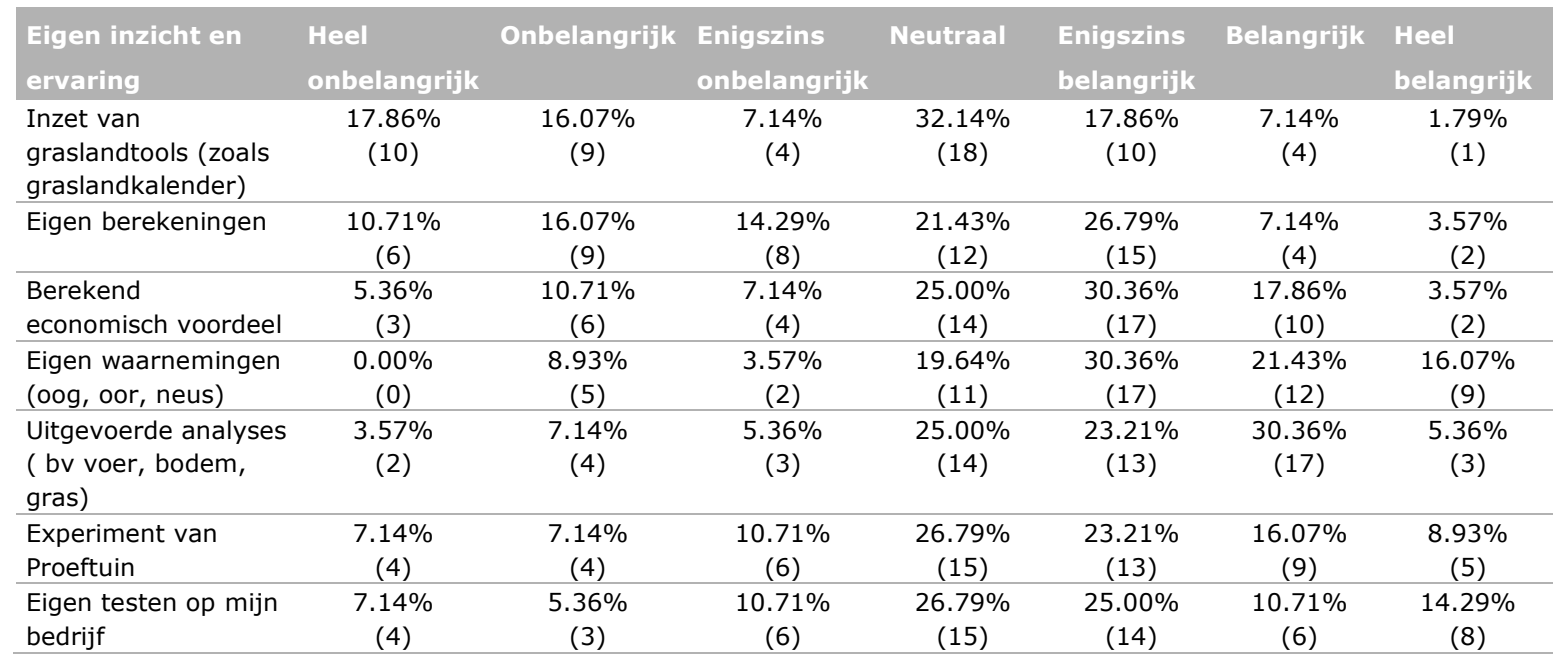

Volgorde van eigen inzicht en ervaring t.a.v. het belang voor de geënquêteerde melkveehouders om ammoniak reducerende maatregelen te nemen:
1. Eigen waarnemingen (oog, oor, neus)
5.00
2. Uitgevoerde analyses ( bv voer, bodem, gras)
4.70
3. Eigen testen op mijn bedrijf
4.46
4. Experiment van Proeftuin
4.36
5. Berekend economisch voordeel
4.32
6. Eigen berekeningen
3.73
7. Inzet van graslandtools (zoals graslandkalender) 


\section{Bijlage 6 Kennisvergaring}

Belangrijkste kennisbronnen van de geënquêteerde melkveehouders veehouders in aflopende volgende:

1. Studiegroep

$22.81 \%(39)$

2. Vakbladen

$17.54 \%(30)$

3. Adviseur van de voerfabriek

$15.20 \%(26)$

4. Onafhankelijke adviseur

$8.19 \%(14)$

5. Informatiedagen zoals demodagen, open dagen, themadagen, etc.

$8.19 \%(14)$

6. Internet

$8.19 \%(14)$

7. Collega melkveehouders

$7.60 \%(13)$

8. Onafhankelijke onderzoeksresultaten

$7.02 \%(12)$

9. Sociale media (Twitter, Instagram, Facebook, etc.)

$2.34 \%(4)$

10. Anders, namelijk:

$2.34 \%(4)$

- VBBM

- Aeromix van Bos Benelux, flinke verbeteraar voor de mest, verlaging ammoniak, wij gaan het nu toepassen in de nieuwe stal

- Oudere veehouders

- VBBM

11. Dierenarts

$0.58 \% \quad(1)$ 


\section{Bijlage 7 Belemmeringen}

Tabel A Belemmeringen die de geënquêteerde melkveehouders ervaren om (nog meer) veranderingen in hun bedrijfsmanagement door te voeren om de ammoniakuitstoot te verminderen.

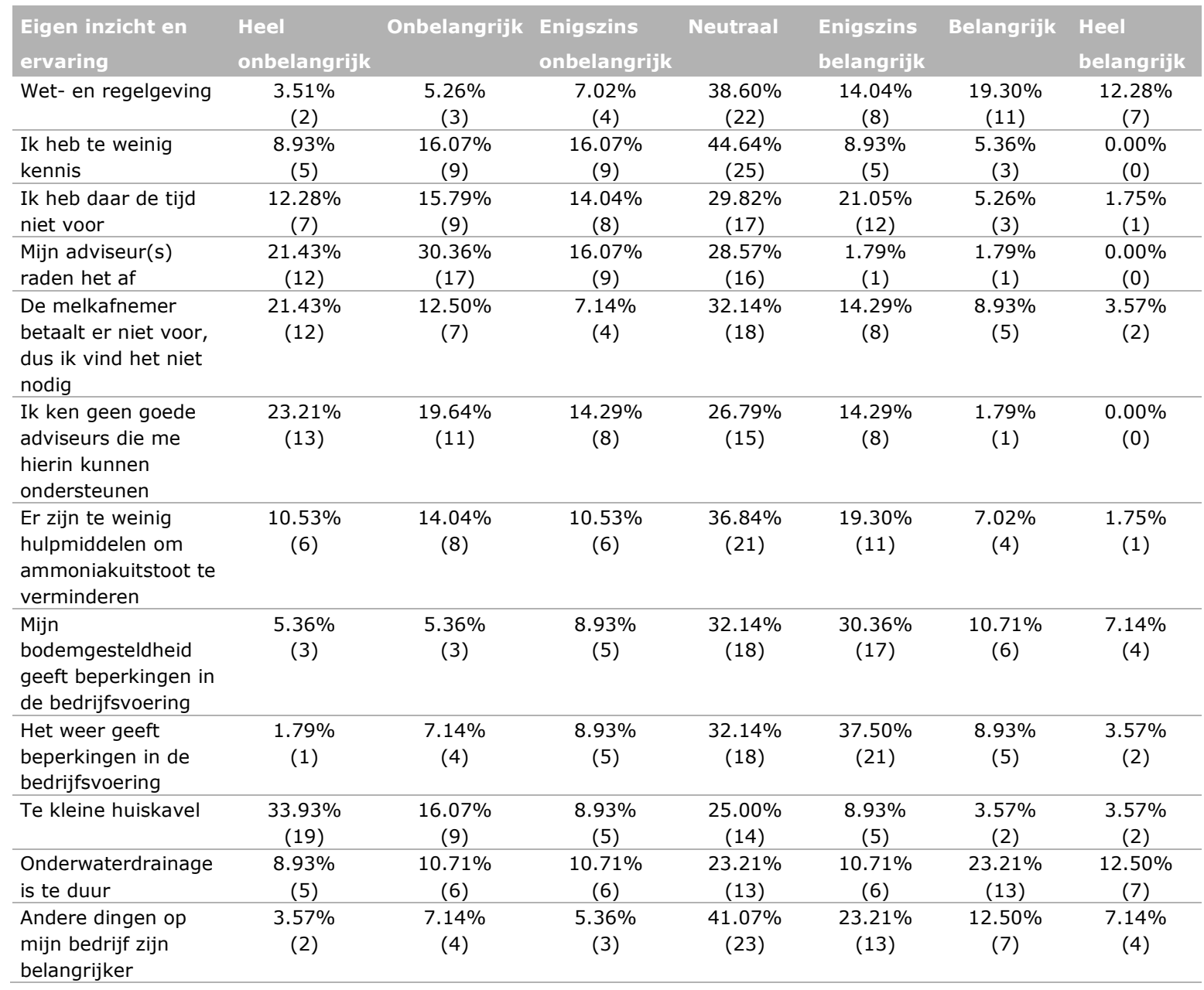

Mate van belangrijkheid van de belemmeringen op een score van 1 tot 7 (van heel onbelangrijk tot heel belangrijk):

1. Wet- en regelgeving

4.61

2. Andere dingen op mijn bedrijf zijn belangrijker

4.39

3. Mijn bodemgesteldheid geeft beperkingen in de bedrijfsvoering

4.38 Het weer geeft beperkingen in de bedrijfsvoering

4.38

4. Onderwaterdrainage is te duur

4.36

5. Er zijn te weinig hulpmiddelen om ammoniakuitstoot te verminderen

3.68

6. Ik heb daar de tijd niet voor

3.54

7. De melkafnemer betaalt er niet voor, dus ik vind het niet nodig

3.46

8. Ik heb te weinig kennis

3.45

9. Ik ken geen goede adviseurs die me hierin kunnen ondersteunen

2.95

10. Te kleine huiskavel

2.84

11. Mijn adviseur(s) raden het af

2.64 


\section{Bijlage 8 Doelen Duurzame Zuivelketen}

Tabel A Mate van belangrijkheid van de geënquêteerde melkveehouders t.a.v. de doelen van de Duurzame Zuivelketen.

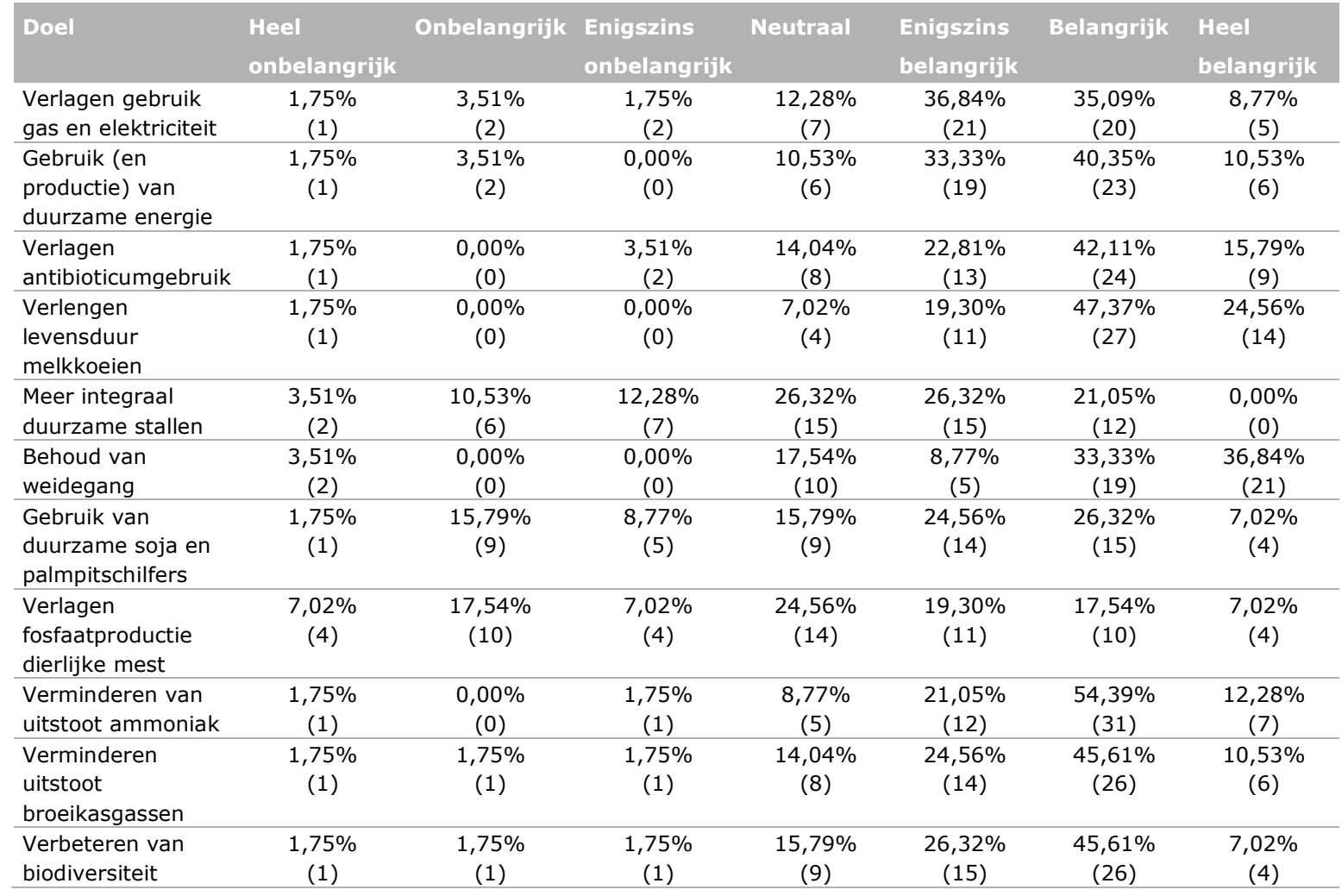

Gemiddelde score van de doelen van de Duurzame Zuivelketen van de respondenten op een score van 1 tot 7 (van heel onbelangrijk tot heel belangrijk):
1. Verlengen levensduur melkkoeien
2. Behoud van weidegang
3. Verminderen van ammoniakuitstoot
4. Verlagen antibioticumgebruik
5. Verminderen uitstoot broeikasgassen
6. Gebruik (en productie) van duurzame energie
$(5,33)$
7. Verbeteren van biodiversiteit
8. Verlagen gebruik gas en elektriciteit
9. Gebruik van duurzame soja en palmpitschilfers
$(4,53)$
10. Meer integraal duurzame stallen
11. Verlagen fosfaatproductie dierlijke mest
$(4,12)$ 


\section{Bijlage 9 Mindset ondernemer}

Tabel A Mate van belangrijkheid van hoe belangrijk deze uitspraken zijn voor de geënquêteerde melkveehouders.

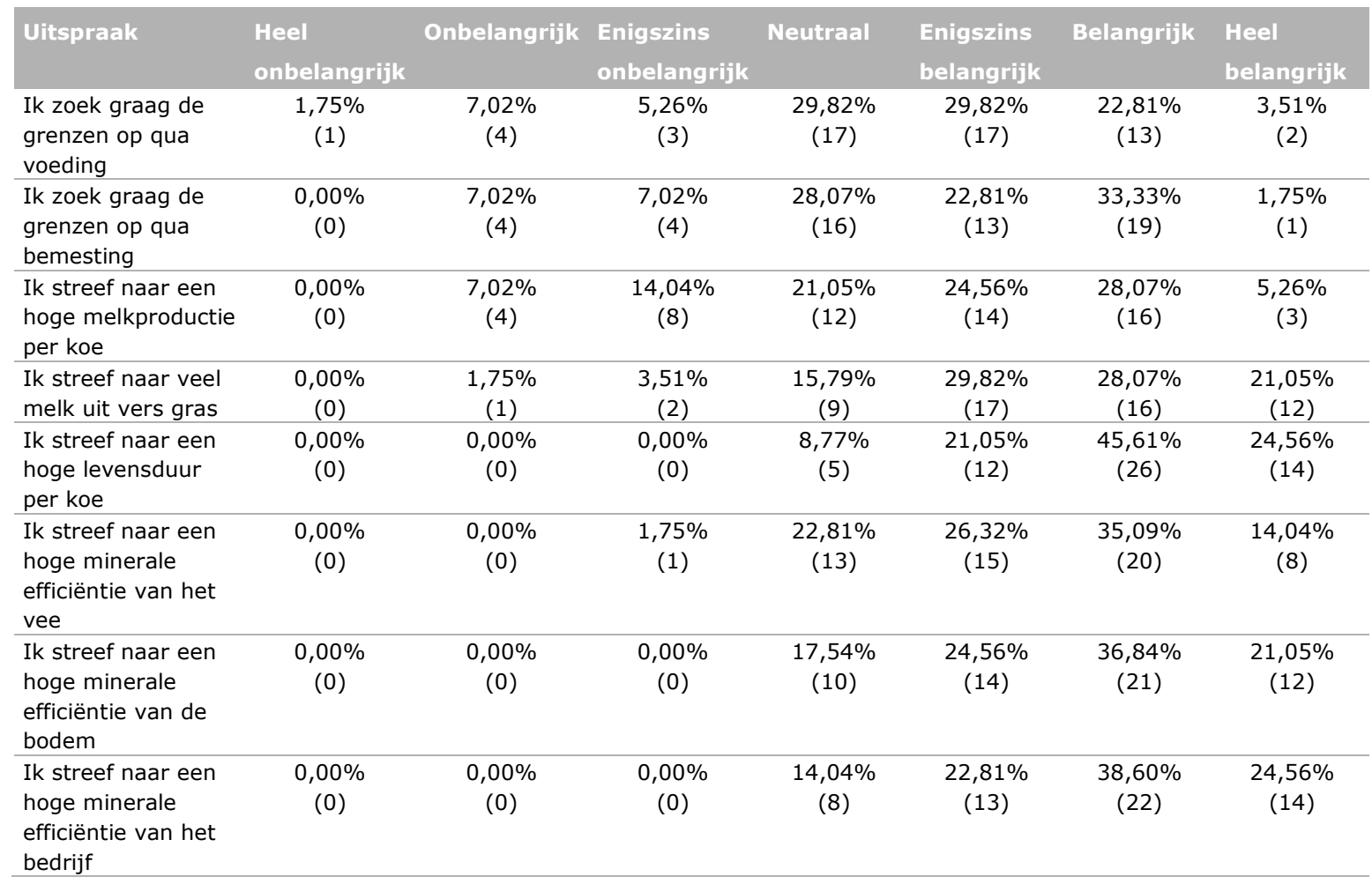

Gemiddelde score van de respondenten over hoe belangrijk ze deze uitspraken vinden op een score van 1 tot 7 (van heel onbelangrijk tot heel belangrijk), gesorteerd van hoog naar laag:
1. Ik streef naar een hoge levensduur per koe
5.86
2. Ik streef naar een hoge minerale efficiëntie van het bedrijf
5.74
3. Ik streef naar een hoge minerale efficiëntie van de bodem
5.61
4. Ik streef naar veel melk uit vers gras
5.42
5. Ik streef naar een hoge minerale efficiëntie van het vee
5.37
6. Ik zoek graag de grenzen op qua bemesting
4.74
7. Ik streef naar een hoge melkproductie per koe
4.68
8. Ik zoek graag de grenzen op qua voeding
4.61 


\section{Bijlage 10 Kennisvergaring proeftuin}

Tabel A Mate van belangrijkheid van wat communicatie activiteiten aan bruikbare kennis heeft opgeleverd voor de geënquêteerde veehouders.

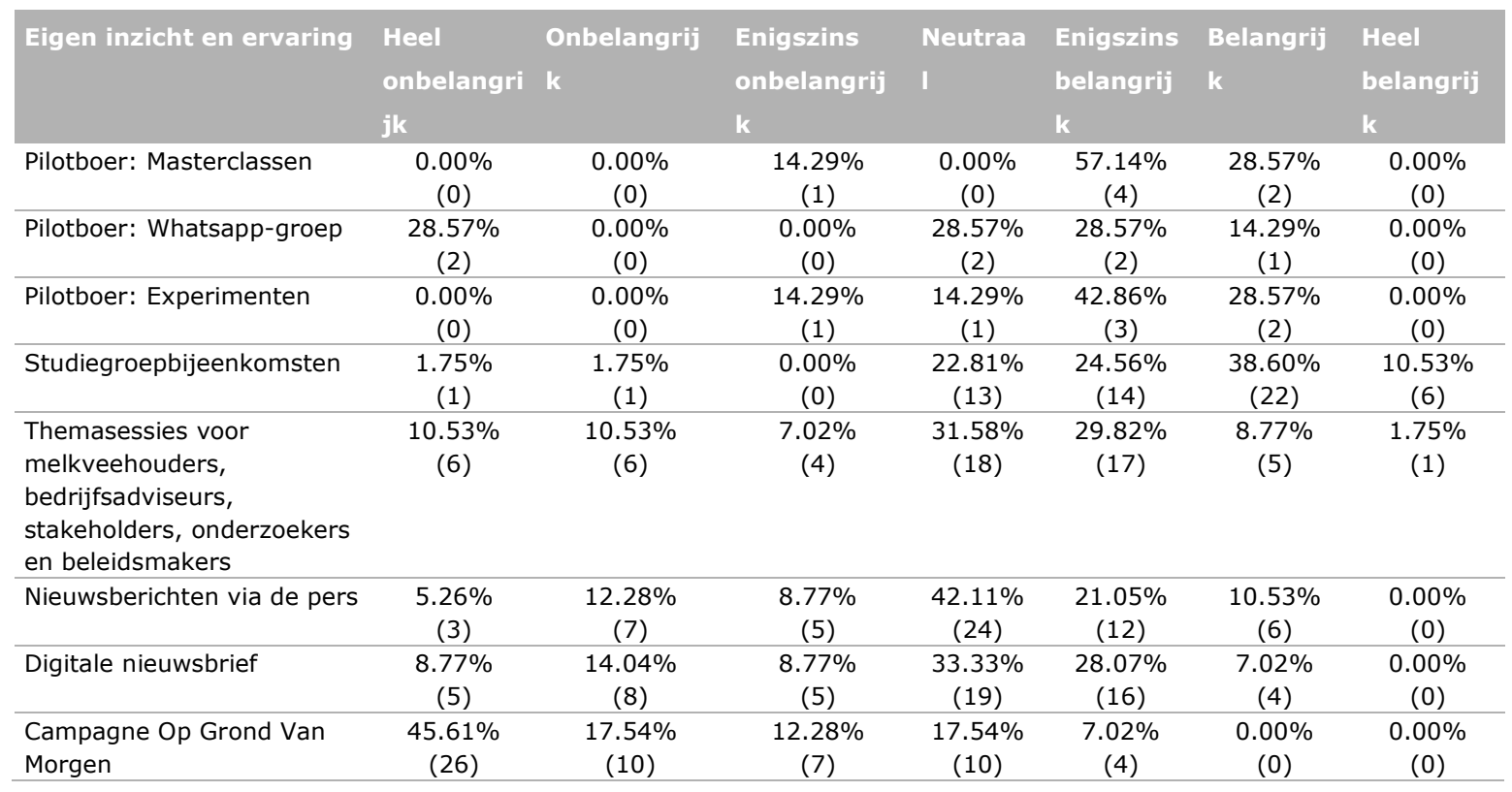

Gemiddelde score van de respondenten over hoe welke communicatie bruikbare kennis heeft opgeleverd op een score van 1 tot 7 (van heel onbelangrijk tot heel belangrijk), gesorteerd van hoog naar laag:
1. Studiegroepbijeenkomsten
5.25
2. Pilotboer: Masterclassen
5.00
3. Pilotboer: Experimenten
4.86
4. Themasessies voor melkveehouders, bedrijfsadviseurs, stakeholders, onderzoekers en beleidsmakers
3.93
5. Nieuwsberichten via de pers
3.93
6. Digitale nieuwsbrief
3.79
7. Pilotboer: Whatsapp-groep
3.71
8. Campagne Op Grond Van Morgen
2.23

De volgende toelichtingen zijn gegeven waarom bepaalde kennis wel of niet bruikbaar was:

- De waarden waar nu van wordt uitgegaan zijn aangenomen waarden en niet de daadwerkelijke waarden, verder lees ik weinig en heb meer aan mondelinge bijeenkomsten als studiegroep of demodagen.

- Het heeft mij meer de bevestiging gegeven dat de bedrijfsvoering die ik nastreeft de juiste is en die bedrijfsvoering is heel anders dan ooit op school geleerd maar gaat meer uit van gevoel.

- Ik ben al eerder dan 2016 omgegaan in denken over voedsel produceren ik wil proberen de natuurlijke processen te optimaliseren, dus zo min mogelijk de techniek het op te laten lossen dan komt er weer een volgend probleem.

- Via studiegroep: ervaringen collega's. Via pers: type machines.

- Mest met water verdunnen voor minder ammoniak emissie, koeien weiden geeft een lagere emissie, eiwit armere brokken kopen.

- Campagne op grond van morgen is mij niet bekend.

- Bij de proeftuinen werd alles met cijfers onderbouwt. Dat geeft een mooi beeld.

- Ik heb een sleuven vloer stal voor de melkkoeien. De ligplaatsen worden opgestroopt met stro. Er is weinig contact urine/mest. Mest, stro fractie word buiten stal opgeslagen. 
Kringloopwijzer zegt: opslag drijfmest is o.k. uitrijden vaste mest is niet o.k. volgens klw vaste mest niet meer toe passen, en ook de mest de kelder in. Dit wil ik niet omdat vaste mest een meerwaarde heeft volgens mij. Laten we ons BOEREN VERSTAND blijven gebruiken. Ik vraag mij wel eens af, BESTAAT DIE NOG. (René Jochems).

- Dat we door wet-regelgeving gedwongen worden om minder ammoniak uit te stoten. Ik heb alleen het idee dat het via mest uitrijden te weinig voortgang in zit. De afschaffing van de sleepvoet is voor alle bedrijven in de proeftuin een doorn in het oog. Een nieuwe bemester kost al snel rond de 25.000. Een enorme investering. Het heeft mij wel verdere inzichten gegeven in de omzetting van nutriënten, door middel van water neemt het gewas meer voedingsstoffen op. Vanuit eigen onderzoek vanuit CAH Dronten kwam dit ook naar voren. Water bij de mest is voor alle facetten het beste. Mocht dit allemaal niet werken, dan zal de regering weer gaan ingrijpen in de veestapel, dit geeft mij zorgen.

- Studiegroepbijeenkomsten: informatie over mest verdunnen. Themasessies: niet bezocht.

- Ben altijd al gefocust op deze dingen, dus vergaar je zo vanzelf kennis. En ik heb er ook plezier in. maar als volledig graslandbedrijf heb je ook zo je beperkingen. stalmaatregelen zijn te duur, landmaatregelen zijn interessanter.

- Bemesten bij de juiste bodemtemperatuur en rekening houden met weersomstandigheden. Meestal goed uitvoerbaar, maar dit jaar soms ook moeilijk. Toepassen lasagne kuil t.b.v. constanter rantsoen in de winter.

- Regelgeving Invoeren nieuwe wetten Inzicht Tools om regelgeving toe te passen.

- Op ons bedrijf, als mest geïnjecteerd gebruikte wel altijd 20\% water. Dit is in $201740 \%$ water en dit jaar $50 \%$ water, van de zomer een paar keer $70 \%$. Het resultaat was overweldigend. We kunnen alle boeren aanraden. De groei bleef erin.

- Geen Whatsapp-groep met elkaar. STUDIEgroepbijeenkomst met klokpomp water toevoegen bij mest. Experimenten met onderwaterdrainage tijdig reageren op weersverwachtigingen en voldoende buffer houden in de herfst.

- De studiegroepbijeenkomsten geven veel kennis en inzicht, zowel theoretisch als praktisch. Er wordt veel informatie verschaft, maar de vergelijking met collega veehouders is ook zeer waardevol. De nieuwsbrieven zijn informatief en ondersteunend en herhalend aan de studiegroepbijeenkomsten.

- $\quad$ Studiegroep het meest digitaal en nieuwsbrief wordt soms heel leuk geschreven dan twijfel ik wel eens aan de haalbaarheid.

- Veel onderzoeken zijn niet toegespitst op veengrond.

- Nieuwsberichten en nieuwsbrief geven eenzijdige informatie, hype gevoelig en vanuit bepaald belang geschreven. Studiegroepbijeenkomsten en themasessies geven interessante interacties.

- In de studiegroep hoor je ervaringen van andere veehouders

- Studiegroepen waren niet altijd een succes, veel gepraat weinig vooruitgang. Lag vooral aan enkele deelnemers, wellicht vooraf beter selecteren op motivatie. Digitaal is niet mijn ding, vakbladen wel. Campagne op grond van morgen is mij niet bekend.

- Digitale nieuwsbrief niet omdat meestal al besproken in studieclub. Campagne Op grond van Morgen: nooit van gehoord.

- Met veehouders sparren werkt super. Campagne Op grond van morgen was niet heel duidelijk aanwezig.

- $\quad$ Proeven met verdunnen drijfmest.

- Leer meeste van collega melkveehouders die al dingen uitproberen zoals rooster druppelaar om roosters schoner te houden wat ik nu ook heb slangenhaspel met omgekeerde sproeikop is zeer interessant maar regelgeving laat het nog niet toe dus ga ik daar nog niet in investeren.

- Campagne Op Grond van Morgen is mij onbekend. In studiegroepverband, ook proeftuinveenweiden, doe je veel kennis op over deze materie door input van externe deskundigen en ervaringen van studiegroepleden en eigen ervaringen. Uit de vakbladen neem je mee wat je van pas komt. Op internet is heel veel informatie te vinden van wetenschap en mensen die het toepassen op hun bedrijf. 


\section{Bijlage 11 Verloop van Proeftuin Veenweiden}

De respondenten van de enquête gaven de volgende zaken waar ze tevreden over waren:

- Er wordt geprobeerd een weg in te slaan om ammoniak te reduceren in veenweidegebieden.

- Er komt meer aandacht voor bodemleven, het onderdeel wat mijn inziens altijd ontbroken heeft en juist een wezenlijk onderdeel is van de kringloop.

- Ik kan mijn verhaal kwijt.

- Kennis overdracht collega boeren.

- Alles goed gelopen geen tekortkomingen.

- Tevreden over info ammoniak maatregelen uitnodiging per mail enz.

- De samenwerking tussen ppp-agro, wur en de pilotboeren. Het uitvoeren van proeven op praktijkschaal.

- Aandacht voor ammoniak.

- Je krijgt goede begeleiding en uitleg.

- De goede wil en inzet van de cursusleider.

- Het in beeld brengen van de uitstoot en maatregelen om ze te reduceren.

- Zeker! De bijeenkomsten zijn altijd leerzaam en het is leuk om te leren van collega veehouders.

- De bijeenkomsten bij collega veehouders, goede kleine duidelijke bijeenkomsten.

- Bezoeken van elkaars bedrijven - evalueren van elkaars werkwijze - Kennis begeleiden \& de lage kosten van deelname.

- Kennis uit de studiegroep.

- Groep boeren om een voorloopbedrijf.

- Kennisuitwisseling praktische toepassingen.

- Het was gezellig en leuk en leren van elkaar.

- Wordt onder aandacht gebracht Kennisoverdracht.

- Interactie in de studiegroep kennisuitwisseling.

- Kan niets verzinnen.

- De adviseur Teus Verhoeff, goede voorlichting gehad.

- Hoeveelheid media aandacht het gehad heeft.

- Korte reistijd naar deelnemers en de deelnemers van de groep .De cursus begeleider.

- Groepsproject is erg leerzaam.

- Over de vorm en inhoud van de bijeenkomsten van de proeftuin.

- Goede begeleiding.

- Inzicht in krachtvoer op ureum. Bewustwording van de juiste bedrijfsvoering.

- De begeleider.

- De interacties van de leden, de begeleiding, de voorbereiding, de organisatie en verslaglegging.

- In de bijeenkomsten kan ieder zijn mening geven.

- Aantal bijeenkomsten.

- De studie groepen.

- Op de bedrijven kijken en vergelijken.

- De kennis van PPP in het algemeen.

- Veel informatie verstrekt.

- Sfeer in groep.

- Goed dat er een project is waar boeren hun bijdrage kunnen leveren om te bewijzen dat het in onze sector gaat zoals het gaat. Men (de overheid met name) denk wel eens dat het op een andere manier effe beter kan, maar in de praktijk gewoon niet toepasbaar is.

- De bijeenkomsten en de communicatie.

- De begeleider, de onderwerpen, de collega's.

- Kennis die werd gedeeld. 
- Contact met collega's en adviseurs.

- Redelijk.

- Contacten, informatie voorzieningen duidelijke leiding en informatie. Proeven die uitgevoerd worden.

- Mooi project goede begeleiding lastig om met lager ruw eiwit in voer toch nog te kunnen melken.

- Begeleiding groep.

- Pilot boer Jan Graveland.

- Aangedragen kennis door externe deskundigen, de begeleider van de groep en collega's.

- Opzet (avondprogramma met theorie en rondje door de stal) en onderwerpen die aan de orde komen.

- Over onderzoeken die ze uitvoeren.

De respondenten van de enquête gaven de volgende zaken waar ze ontevreden over waren:

- Dat er uitgegaan van aangenomen waarden en niet daadwerkelijk gemeten waarden. Mest uitrijden op veenweidegebieden met sleepvoet wordt afgeschaft, insnijden is nadelig voor de veenweidegebieden.

- De regelgeving omtrent de mestwetgeving gaat in de basis uit van wantrouwen, daarmee beperk je juist de ontwikkelingen.

- Ik had gehoopt dat de dingen die ik anders doe, zoals een stal met sleuven vloer en stromest, FIR voeren, beter ingevoerd in de kringloop wijzer kunnen worden.

- Ontevreden over onderdeel voeding, krachtvoergift min/max rantsoenen droge koeien, nieuwmelks/oudmelks, jongvee rantsoen.

- De vergelijking van de pilotboeren onderling om zo nieuwe kennis inzichten te krijgen.

- Aandacht voor bodemdaling / diepgang studieclubs.

- Het zou leuk zijn, als er ook financiële cijfers naast kunnen.

- Het is allemaal aannamebeleid op papier voor de gangbare bedrijven, maar niet voor bedrijven die het anders doen.

- $\quad$ Er zou een grotere focus moeten liggen op wat je bij moet voeren bij de gewonnen gras van dat jaar om een hogere efficiëntie te krijgen en minder uitstoot.

- De haalbaarheid van behaalde resultaten. Het is allemaal zo erg seizoensgebonden. De echte daad bij woord voegen leeft niet $100 \%$. Het is moeilijk om op dit onderdeel te sturen binnen je bedrijf, want hoe je het wend of keert, als je alleen op ammoniak gaat letten, laat je op andere punten in je bedrijf steken vallen.

- Dat Aeromix nog niet is toegelaten als ammoniakemissie verlager als toepasbaar i.p.v. kleppen in de roosters.

- $\quad$ Erg veel nadruk op beweiden geloof er niet in dat het beter is voor de koe.

- Niet, maar hoe nu verder.

- Diepgang en voorbeelden hoe we kunnen scoren.

- Technische vooruitgang.

- Er komen nog maar weinig concrete dingen uit waar je wat mee kan.

- Het kost tijd, maar zeer leerzaam.

- Hoe er met het geld word omgegaan.

- Het wordt allemaal veel te theoretisch.

- Deze enquête mag korter en bondiger.

- De uitnodiging voor de bijeenkomst was al regelmatig zo laat, dat het onmogelijk voor mij was om de bijeenkomst bij te wonen.

- $\quad$ Bv onderzoek slootwater moet volgens mij vaker om een goed beeld te krijgen.

- $\quad 10.00$ tot 12.30 altijd 10.30 tot 13.30 .

- Niets.

- Niets.

- Alles was goed.

- Haalbaarheid van gestelde doelen.

- Te weinig op eigen bedrijf gericht, te algemeen.

- Het verloop van de studiegroepen rond de pilotbedrijven. Pilotbedrijf speelde niet echt een belangrijke rol, we waren meestal op een ander bedrijf. Naar mijn idee volg je het pilotbedrijf 
en spiegel je het eigen bedrijf. Daarvoor is regelmatig bezoek aan het pilotbedrijf belangrijk om ook te zien en te ervaren wat er gebeurd.

- Gemekker door adviseurs en media over eiwitgehalte in gras. Wat je wint hoef je niet te kopen maar dit snappen zij vaak nog niet.

- Ik snap niet dat er nog geen (betaalbaar en betrouwbaar) product is wat toegevoegd kan worden aan de mest, waardoor er minder vervluchtiging is of betere benutting van de stikstof in de mest.

- Het probleem van emissie arme aanwending op onze grond wordt niet echt opgelost.

- Niet duidelijk wat beleidsmakers over hebben voor de geleverde inspanningen.

- Soms erg theoretisch met soms erg veel aannames.

- Op bepaalde vlakken niet heel diepgaand.

- De contacten met collega's en adviseurs mogen meer. Collega's betere begeleiding.

- Geen.

- N.v.t.

- Geen.

- Het is jammer dat er vaker deelnemers verhinderd zijn naarmate het project langer loopt.

- Soms weten we vooraf niet wat het programma van een avond is. voorbereiden is dan niet mogelijk. We kunnen er meer uithalen als we voorbereide opdrachten uitvoeren en meenemen.

- Nergens over.

De respondenten van de enquête gaven de volgende zaken hadden de volgende tips voor het project:

- Meer onderzoek naar daadwerkelijke uitstoot i.p.v. waarden aan te nemen.

- Geef boeren de kans die daar om vragen en naar leven vrijer om te gaan met de regelgeving.

- Zorg er voor dat boeren die aan dit soort projecten mee doen niet gestraft worden als er straks toch weer generiek gekort moet worden ,denk aan stikstof plafond.

- Soms een deskundige uitnodigen over bepaalde onderwerpen.

- Meer in gaan op voeding en kuiluitslagen.

- $\quad$ Nu de eerste resultaten bekend zijn om de NH3 te reduceren moeten we nu doorpakken met een vervolg van de pilot. En meer inzetten op eiwit arme rantsoenen.

- Meer actieve discussie organiseren over hoe deelnemers op hun bedrijf handelen.

- Doe werkelijke metingen van de activiteiten die gedaan worden. Als je alleen met de aannames op papier werkt, dan kan je het alleen via de mail af. Dan heeft het geen zin om het in werkelijkheid uit te proberen om te kijken of het resultaat heeft.

- Betere voeding betere mest minder uitstoot.

- $\quad$ Laat een keer een externe spreker of dergelijke invliegen om kennis te vergaren. De kennis is mijn ogen te veel theoretisch, waarbij de borging in mijn ogen niet helemaal realistisch is.

- Onderzoek naar mestbeluchting Aeromix. resultaat betere mest, word betere voeding plat, word gezonder gewas, gezonder voer weer voor de koe. cirkel rond.

- Doorgaan, breder trekken dan stikstof/ammoniak.

- Meer inzetten op toevoegmiddelen in de mest voor reductie.

- Misschien kunnen we iets met de geleidbaarheidsmeter naar de toekomst.

- Meer kennis opdoen m.b.t. het bemesten van de bodem op basis van mineralen. Dus niet vooral op basis van N.P.K. Haal er eens een echte bodemecoloog bij.

- Je heb wel meerdere jaren nodig om zichtbaar resultaat te kunnen zien.

- Mee door gaan.

- Water bij de mest is de belangrijkste vooruitgang, laat het met onderzoek nog meer uitkomen. Dan hoeven de grond niet door te snijden, met injecteren. We moeten meer eiwit van ons eigen land af halen.

- Probeer een zeer korte eenvoudige en bruikbare tool te maken. nu is het voor een veehouder niet meer zelf te doen en zijn we over geleverd aan ppp.

- Dieper ingaan op bodem en bemesting.

- Ga door! Blijf enthousiast ondanks de soms stugge boeren.

- Probeer wel dicht bij de praktijk te blijven.

- Voerexpert betrekken bij project en uitleggen hoe je tot verbetering komt met andere grondstoffen.

- Het is prima zo! 
- Heb ik niet.

- Individueel per bedrijf 2 bezoeken, vooraf doelstelling naderhand resultaten bespreken.

- Selectie op motivatie van de deelnemers en kleinere groepen met boeren die echt vooruit willen. Dat scheelt een hoop geklets in de studiegroep.

- Geen.

- Wij zijn een redelijk intensief bedrijf en moeten jaarlijks mest afvoeren vanwege stikstof overschot (niet vanwege de fosfaat). Tegelijk mogen we wel kunstmest stikstof aankopen. Zou dus heeeeel graag zien dat er een hogere derogatienorm komt, met eventueel lager plafond in kunstmest aankoop.

- Er word wel makkelijk gezegd dat we minder eiwit in het rantsoen kunnen doen maar wel effect heeft het op de melkproductie.

- Proberen duidelijk te krijgen waar voor ons dan daadwerkelijk een plus te halen is in financiële zin.

- Doorgaan zo.

- Meer resultaat gericht.

- Meer contact met collega's.

- Ook milieu nog meer meenemen zoals co2 methaan, ect.

- Is leer proces is lastig om mede ondernemers te overtuigen en oude gewoontes zijn slecht uit te bannen.

- Niet alleen voerspoor kijken naar mest maar ook hoe reageert mest met toevoegen andere producten (strooisel, gesteentemeel, kalk, paardenmest).

- Meer input van kennis over de biologie in de bodem in relatie tot de minerale efficiëntie.

- Vooraf programma bekendmaken en eventueel huiswerk. 
